\title{
WestVirginiaUniversity
}

THE RESEARCH REPOSITORY @ WVU

Graduate Theses, Dissertations, and Problem Reports

2001

\section{Factors influencing crosslink formation in muscle tissue}

\author{
Maricica Pacurari \\ West Virginia University
}

Follow this and additional works at: https://researchrepository.wvu.edu/etd

\section{Recommended Citation}

Pacurari, Maricica, "Factors influencing crosslink formation in muscle tissue" (2001). Graduate Theses, Dissertations, and Problem Reports. 1336.

https://researchrepository.wvu.edu/etd/1336

This Thesis is protected by copyright and/or related rights. It has been brought to you by the The Research Repository @WVU with permission from the rights-holder(s). You are free to use this Thesis in any way that is permitted by the copyright and related rights legislation that applies to your use. For other uses you must obtain permission from the rights-holder(s) directly, unless additional rights are indicated by a Creative Commons license in the record and/ or on the work itself. This Thesis has been accepted for inclusion in WVU Graduate Theses, Dissertations, and Problem Reports collection by an authorized administrator of The Research Repository @ WVU. For more information, please contact researchrepository@mail.wvu.edu. 


\title{
Factors Influencing Crosslink Formation in Muscle Tissue
}

\author{
Maricica Pacurari
}

Thesis submitted to the College of Agriculture, Forestry and Consumer Sciences at West Virginia University

in partial fulfillment of the requirements for the degree of

Master of Science
In

Animal \& Veterinary Sciences

Hillar Klandorf, Ph.D., Chair

P. Brett Kenney, Ph.D.

Dale Porter, Ph.D.

\section{Division of Animal \& Veterinary Sciences}

Morgantown, West Virginia

2001

Keywords: Collagen, ALT-711, Crosslinks, Cattle, Tenderness 


\section{Abstract \\ Factors influencing crosslink formation in muscle tissue}

\section{Maricica Pacurari}

The objectives of this study were to determine the effect of the crosslink breaker ALT-711 on the concentration of soluble collagen, as well as its effectiveness on meat tenderness.

Final body weights were not affected by treatments. Muscle tenderness was higher $(\mathrm{p}<0.05)$ for TB, SS, BF, ST, and LT $(\mathrm{p}<0.10)$ for A-maturity animals compared to control and ALT-711 treated animals. No consistent ALT-711 effect on shear force measurements was found. Shear force increased linearly with age BF, $\mathrm{R}^{2}=0.94 ; \mathrm{SM}$, $\mathrm{R}^{2}=0.81 ; \mathrm{LL}, \mathrm{R}^{2}=0.77 ; \mathrm{SS}, \mathrm{R}^{2}=0.63 ; \mathrm{LT}, \mathrm{R}^{2}=0.32 ; \mathrm{TB}, \mathrm{R}^{2}=0.37 ; \mathrm{ST}, \mathrm{R}^{2}=0.40$. Total collagen content was not different ( $p>0.10)$ between A-maturity, control and ALT-711 treated animals. However, the concentration of soluble collagen was higher $(\mathrm{p}<0.05)$ for A-maturity group. Insoluble collagen content was higher $(\mathrm{p}<0.05)$ for longissimus thoracis, biceps femoris, and $(\mathrm{p}<0.10)$ for supraspinatus of control animals. Muscle soluble collagen content decreased linearly as chronological age increased $\mathrm{LT} \mathrm{R}^{2}=0.98$; $\mathrm{LL} \mathrm{R}^{2}=0.92 ; \mathrm{TB} \mathrm{R}^{2}=0.99 ; \mathrm{BF} \mathrm{R}^{2}=0.99 ; \mathrm{ST} \mathrm{R} \mathrm{R}^{2}=0.95 ; \mathrm{SM} \mathrm{R}^{2}=0.99 ; \mathrm{SS} \mathrm{R}^{2}=0.36$. The soluble collagen percentage was higher for ALT-711 treated animals compared to control animals.

ALT-711 tended to increase muscle soluble collagen content of aged cattle. ALT711 may be an effective age-related collagen crosslink breaker. However, ALT-711 may not be used to improve meat quality of aged cattle. 


\title{
Dedication
}

\author{
This work is dedicated to \\ God \\ and to my daughter Paula
}




\section{Acknowledgements}

Thanks and glory to God.

I wish to express my sincere gratitude to my advisor Dr. Hillar Klandorf for his patience, encouragement, advice, help, and academic guidance, which he offered throughout my study.

My sincerest appreciation is extended to Dr. P. B. Kenney for his academic and professional guidance, help, and encouragement during my study.

I would like to thank to Dr. D. Porter for academic guidance, moral support, and for serving in my committee, Dr. K. Blemings, Dr. J. Killefer, Dr. W. Thayne and Dr. E. Priggie for their academic guidance. I also extend my sincerest gratitude to Dr. J. Warren.

Thanks are extended to lab technicians Susan Slider, Diana Keller, Tammy Webster, Elizabeth Falkenstein, Juanita Engels, and Rodney Kiser for their technical support. Also I thank to Rick Wood and Sara Beamer for their help at the farm.

I thank and gratefully acknowledge the help offered by, Rick Chaney during the experiment period and in the lab, Josh Mathias, Sara Peacock, Brandon.

A special thanks is extended to Mr. Jones for his generous help and leadership skill offered for the transport of animals, and to farm crew who gave me the help and support during this project.

I am very grateful to the West Virginia University, especially to Division of Animal and Veterinary Sciences for giving the opportunity to study and for the assistantship, which is duly acknowledged.

Last, but not least, I am grateful to my dear husband and daughter for their immense encouragement especially in difficult times, to my mom and brothers, and I wish my father could shear with me my great accomplishments.

'Thank you' to the faculty and fellow graduate students of the Division of Animal and Veterinary Sciences, and to West Virginia University. 


\section{Table of contents}

\section{Factors Influencing Crosslink Formation in Muscle Tissue}

\begin{tabular}{|lr|}
\hline Abstract & $i i$ \\
\hline Acknowledgements & iv \\
\hline Table of contents & v \\
\hline List of figures & vii \\
\hline List of tables & ix \\
\hline I. Introduction & 1 \\
\hline $2 . \quad$ Literature Review & 5 \\
\hline
\end{tabular}

\begin{tabular}{|lll}
\hline $2.1 \quad$ Collagen and striated muscles & 5 \\
\hline
\end{tabular}

\begin{tabular}{lll}
2.2 & Collagen biosynthesis and cross-linking & 7 \\
\hline
\end{tabular}

$2.2 .1 \quad$ Collagen biosynthesis 7

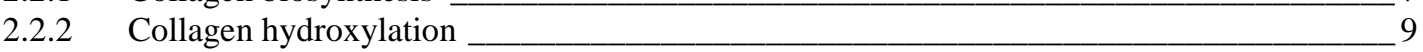

\begin{tabular}{lll}
2.3 & Types of collagen crosslinking & 10 \\
\hline
\end{tabular}

$2.3 .1 \quad$ Collagen crosslinking

$2.3 .2 \quad$ Enzymatic collagen crosslinking: lysyl oxidase's role__

\begin{tabular}{|lll}
\hline 2.4 & The Maillard reaction and collagen crosslinking & 14 \\
\hline
\end{tabular}

$2.5 \quad$ Advanced glycation end-products and extracellular matrix changes $\quad 16$

$2.6 \quad$ Muscle development 17

\begin{tabular}{lll}
$2.6 .1 \quad$ Cellular events & 17 \\
\hline 2.6 .2 & 17
\end{tabular}

$2.6 .2 \quad$ Muscle histochemistry ___ 18

$2.7 \quad$ Factors affecting cross-links formation in muscle tissue $\quad 19$

$2.7 .1 \quad$ Age and Growth 20

\begin{tabular}{|lll}
\hline 2.7 .2 & Growth rate and animal duration on concentrate diet & 21 \\
\hline
\end{tabular}

$2.7 .3 \quad$ Rapid or Compensatory Growth 22

$2.7 .4 \quad \mathrm{pH}_{2}$

$2.8 \quad$ Prevention of glucose-derived protein crosslinks 24

$2.8 .1 \quad$ Physiological intervention 24

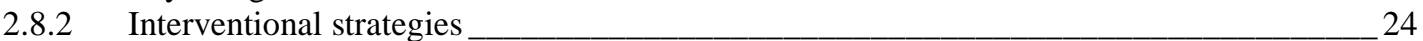

2.8 .3 Pharmacological intervention on AGEs accumulation 25

$2.8 .4 \quad$ ALT-711 mode of action _ 26

3. Materials and Methods_ 29

\begin{tabular}{|lll}
\hline $3.1 \quad$ Animals and Management _ & 29 \\
\hline
\end{tabular}

\begin{tabular}{|lll}
\hline $3.2 \quad$ Color determination & 30 \\
\hline
\end{tabular}

\begin{tabular}{lll}
\hline 3.3 & Warner-Bratzler Shear Force ___ & 30 \\
\hline
\end{tabular}

\begin{tabular}{|llll}
\hline 3.4 & Cooking loss & 31 \\
\hline
\end{tabular}

\begin{tabular}{|llll}
\hline 3.5 & Soluble and insoluble Collagen ___acem & 31 \\
\hline 3.6
\end{tabular}

\begin{tabular}{|lll}
\hline $3.6 \quad \mathrm{pH}$ measurements & 32 \\
\hline
\end{tabular} 
3.7 Plasma Glucose 33

\begin{tabular}{|llr}
\hline 3.8 & Sarcomere length & 33 \\
\hline
\end{tabular}

\begin{tabular}{|lll|}
\hline 3.9 & Statistical Analysis & 34 \\
\hline
\end{tabular}

\begin{tabular}{llr}
\hline 4. & Results & 34 \\
\hline
\end{tabular}

\begin{tabular}{|llr|}
\hline 4.1 & Carcass & 34 \\
\hline
\end{tabular}

$4.2 \quad$ Fat thickness 36

\begin{tabular}{|lll|}
\hline 4.3 & Color & 38 \\
\hline
\end{tabular}

\begin{tabular}{|lll}
4.4 & Cooking time & 42 \\
\hline
\end{tabular}

\begin{tabular}{|lll}
\hline 4.5 & Cooking loss & 42 \\
\hline
\end{tabular}

$4.6 \quad$ Shear force 43

$4.7 \quad \mathrm{pH} 45$

\begin{tabular}{|llr}
$4.8 \quad$ Soluble, insoluble, and total collagen & 47 \\
\hline
\end{tabular}

\begin{tabular}{lll}
$4.8 .1 \quad$ Total collagen & 47 \\
\hline
\end{tabular}

$4.8 .2 \quad$ Insoluble collagen _47

\begin{tabular}{llll}
\hline 4.8 .3 & Soluble collagen & 48 \\
\hline
\end{tabular}

\begin{tabular}{rrr}
\hline 1.8 .4 & Soluble collagen percentage & 52 \\
\hline
\end{tabular}

\begin{tabular}{lll}
\hline 4.8 .5 & Sarcomere length 55 \\
\hline 7.8 .6 & & 56
\end{tabular}

4.8 .6 Plasma Glucose ___________ 56

\begin{tabular}{llr}
\hline 5. & Discussion & 57 \\
\hline
\end{tabular}

\begin{tabular}{llr}
\hline 6. & Conclusions & 68 \\
\hline 7
\end{tabular}

\begin{tabular}{|lr}
\hline 7. & REFERENCES \\
\hline
\end{tabular} 


\section{List of figures}

Figure 2-1. Schematic illustration of mature, immature and glucose derived cross-link formation on collagen molecules. (Adapted from Bailey et al. 1989).

Figure 2-2. Scheme for the formation of glucose-derived protein crosslink from Amadori Product (a) and cleavage by thiazolium breaker (PTB) (b). I= Protein-bound (Lys) Amadori product (AP), II= AP-dione, III= AP-ene-dione, IV= Stable protein-protein crosslink, PTB=N-Phenacylthiazolium bromide. (Adapted from Vasan et al., 1996).

Figure 4-1. Initial and final body weights of each treatment group. Each bar represents the mean $(n=5) \pm$ SEM. ${ }^{a}$ Means with same superscript are not different $(p>0.05)$. Alt$711=$ Treated, Saline $=$ Control..................................................................... 36

Figure 4-2. Fat thickness for each treatment group. Each bar represents the mean $(n=5) \pm$ SEM. ${ }^{a}$ Means with same superscript are not different $(\mathrm{p}>0.05)$. Alt-711=Treated, Saline=Control, A-mat.=A-maturity ............................................................ 37

Figure 4-3. Relationship between fat thickness and the number of days on feed. Group 1=51days, group 2=66 days, group 3=88 days, group 4=91 days, group 5=101 days. Alt-711=Treated, Saline $=$ Control.

Figure 4-4. Relationship between Lightness (L*) and muscle types. Each bar represents the mean $(\mathrm{n}=5) \pm$ SEM. ${ }^{\mathrm{a}-\mathrm{c}}$ Means with different superscript are different $\left(\mathrm{p}<0.05^{*}\right.$ and $\left.\mathrm{p}<0.10^{* *}\right)$. LT=Longissimus thoracis, $\mathrm{LL}=$ Longissimus lumborum, $\mathrm{TB}=$ Triceps brachii, $\mathrm{SS}=$ Supraspinatus, $\mathrm{ST}=$ Semitendinosus, $\mathrm{BF}=$ Biceps femoris, SM=Semimebranosus, C=Control, Alt-711=Treated, A-mat. =A-maturity.

Figure 4-5. Age and Alt-711 treatment effect on muscle tenderness (shear force). Each bar $(n=5)$ represents the mean \pm SEM. ${ }^{a-c}$ Means with different superscript are different $\left(\mathrm{p}<0.05^{*}\right.$ and $\left.\mathrm{p}<0.10^{* *}\right)$. LT=Longissimus thoracis, LL=Longissimus lumborum, $\mathrm{TB}=$ Triceps brachii, $\mathrm{SS}=$ Supraspinatus, $\mathrm{ST}=$ Semitendinosus, $\mathrm{BF}=\mathrm{Biceps}$ femoris, SM=Semimebranosus, C=Control, Alt-711=Treated, A-mat. =A-maturity.

Figure 4-6. Changes in muscle tenderness as a function of age. Each sign represents the mean $(\mathrm{n}=5)$ of A-maturity=1.5 years, Alt-711=8.4 years, Control=9.8 years. $\mathrm{LT}=$ Longissimus thoracis, $\mathrm{LL}=$ Longissimus lumborum, $\mathrm{TB}=$ Triceps brachi, $\mathrm{SS}=$ Supraspinatus, $\mathrm{ST}=$ Semitendinosus, $\mathrm{BF}=$ Biceps femoris, $\mathrm{SM}=$ Semimebranosus

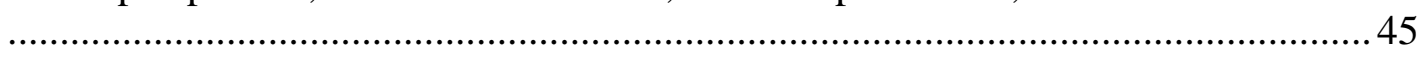


Figure 4-7. Relatonship between muscle and $\mathrm{pH}$. Each bar represents the mean $(\mathrm{n}=5) \pm$

SEM. ${ }^{\mathrm{a}-\mathrm{c}}$ Means with different superscript are different $\left(\mathrm{p}<0.05^{*}\right.$ and $\left.\mathrm{p}<0.10^{* *}\right)$.

$\mathrm{LT}=$ Longissimus thoracis, $\mathrm{LL}=$ Longissimus lumborum, $\mathrm{TB}=$ Triceps brachi,

$\mathrm{SS}=$ Supraspinatus, $\mathrm{ST}=$ Semitendinosus, $\mathrm{BF}=$ Biceps femoris, $\mathrm{SM}=$ Semimebranosus,

$\mathrm{C}=$ Control, Alt-711=Treated, A-mat. =A-maturity........................................46

Figure 4-8. Relationship between soluble collagen and age. Each sign represent the mean $(n=5)$ in the muscles of A-maturity $=1.5$ years, Alt-711=8.4 years, Control $=9.8$ years. LT=Longissimus thoracis, LL=Longissimus lumborum, TB=Triceps brachii, $\mathrm{SS}=$ Supraspinatus, $\mathrm{ST}=$ Semitendinosus, $\mathrm{BF}=$ Biceps femoris, $\mathrm{SM}=$ Semimebranosus.

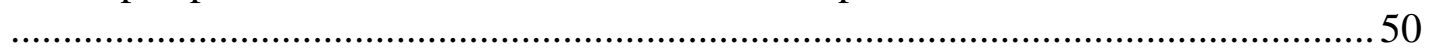

Figure 4-9. Soluble collagen content as function of muscle and treatment. ${ }^{\mathrm{a}-\mathrm{b}}$ Means

within same muscle with different superscript are different $\left(\mathrm{p}<0.05^{*}\right.$ and $\left.\mathrm{p}<0.10^{* *}\right)$.

Each bar represents the mean $(\mathrm{n}=5) \pm$ SEM. LT=Longissimus thoracis,

$\mathrm{LL}=$ Longissimus lumborum, $\mathrm{TB}=$ Triceps brachii, $\mathrm{SS}=$ Supraspinatus,

$\mathrm{ST}=$ Semitendinosus, $\mathrm{BF}=$ Biceps femoris, $\mathrm{SM}=$ Semimembranosus. $\mathrm{C}=$ Control, Alt-

$711=$ Treated, A-mat.=A-maturity. ........................................................... 51

Figure 4-10. Effect of Alt-711 on the percentage of soluble collagen. Each bar represents

the mean $(\mathrm{n}=5) \pm$ SEM. ${ }^{\mathrm{a}-\mathrm{b}}$ Means within same muscle with same superscript are not

different $(\mathrm{p}<0.10)$. LT=Longissimus thoracis, LL=Longissimus lumborum,

$\mathrm{TB}=$ Triceps brachii, $\mathrm{SS}=$ Supraspinatus, $\mathrm{ST}=$ Semitendinosus, $\mathrm{BF}=$ Biceps femoris,

$\mathrm{SM}=$ Semimebranosus. Alt $-711=$ Treated, $\mathrm{C}=$ Control. ...................................52

Figure 4-11. Soluble collagen percentage and treatment groups. Each bar represent the mean $(\mathrm{n}=5) \pm$ SEM. ${ }^{\mathrm{a}-\mathrm{b}}$ Means within same muscle with different superscript are different $\left(\mathrm{p}<0.05^{*}\right.$ and $\left.\mathrm{p}<0.10^{* *}\right)$. LT=Longissimus thoracis, $\mathrm{LL}=$ Longissimus lumborum, TB=Triceps brachi, $\mathrm{SS}=$ Supraspinatus, $\mathrm{ST}=$ Semitendinosus, $\mathrm{BF}=\mathrm{Biceps}$ femoris, $\mathrm{SM}=$ Semimebranosus. Alt-711=Treated, $\mathrm{C}=$ Control, A-mat.=A-maturity.53

Figure 4-12. Relationship between sarcomere length and tenderness (shear force).

$\mathrm{SF}=$ Shear force. ${ }^{\text {ab }}$ Means with different superscript within same muscle are different $\left(\mathrm{p}<0.05^{*}\right.$ and $\left.\mathrm{p}<0.10^{* *}\right)$. Each bar represents the mean $(\mathrm{n}=5) \pm$ SEM. C $=$ Control, ALT-711=treated, A-mat=A-maturity. $\mathrm{LT}=$ longissimus thoracis, $\mathrm{BF}=$ biceps femoris.

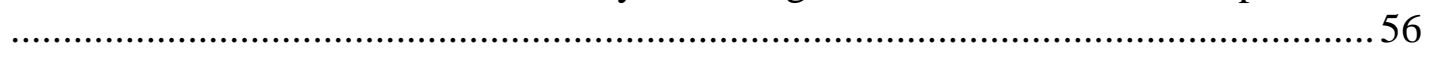

Figure 4-13. Plasma glucose concentrations. ${ }^{\text {a}}$ Means with same superscript are not different $(\mathrm{p}<0.05)$. Each bar represents the mean $(\mathrm{n}=5) \pm$ SE M. $\mathrm{C}=\mathrm{Control}$, Alt$711=$ Treated, A-mat.=A-maturity ..... 


\section{List of tables}

Table 4-1. Carcass characteristics for the control group $(n=5) \ldots \ldots \ldots \ldots \ldots \ldots \ldots \ldots \ldots \ldots \ldots \ldots \ldots \ldots . .35$

Table 4-2. Carcass characteristics for the ALT-711treated group $(\mathrm{n}=5), \ldots \ldots \ldots \ldots \ldots \ldots \ldots \ldots . . .35$

Table 4-3. Carcass characteristics for the A-maturity group $(\mathrm{n}=5) \ldots \ldots \ldots \ldots \ldots \ldots \ldots \ldots \ldots \ldots \ldots \ldots . . . . .36$

Table 4-4. Mean Shear force (SF) values and physical characteristics for longissimus thoracis and longissimus lumborum muscles for the Control, Alt-711 treated, and Amaturity groups. ........................................................................................... 40

Table 4-5. Mean shear force (SF) values and physical characteristics for triceps brachi and supraspinatus muscles for the Control, Alt-711 treated, and A-maturity groups.

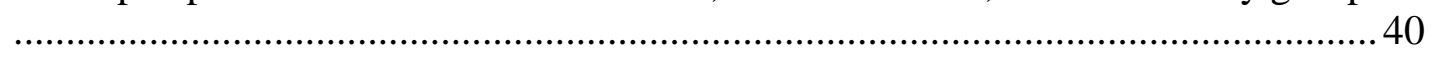

Table 4-6. Mean Shear force (SF) values and physical characteristics for Biceps femoris and Semitendinosus muscles for the Control, Alt-711 treated, and A-maturity groups......................................................................................................... 41

Table 4-7. Mean shear force (SF) values and physical characteristics for Semimembranossus muscle for the Control, Alt-711 treated, and A-maturity groups.

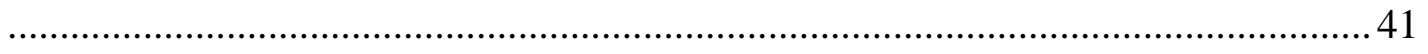

Table 4-8. Effect of age and Alt-711 treatment on collagen characteristics....................49

Table 4-9. Orthogonal contrasts ......................................................................... 54

Table 4-10. Mean sarcomere length and Pearson correlation coefficient $\left(\mathrm{R}^{2}\right)$ between sarcomere length, tenderness (SF), and back fat thickness.....................................55

Table 4-11. Means and glucose ranges for treatment groups ( $\mathrm{n}=5$ per group). ................57 


\section{Introduction}

Morphological, biochemical, and physiological changes that lead to a progressive decline in the functional capacity of an organism is viewed as biological aging (Going et al., 1994). Bjorksten (1962) proposed that the accumulation of intra- and inter-cellular crosslinks might irreversibly inactivate functional molecules and cause the organism to deteriorate in function. Verzar (1964) proposed that the increase in the amount of insoluble collagen with age is due also to protein crosslinking.

The age-related changes in muscle tissue are due to many factors that include connective tissue, age, breed, sex, and nutrition. While age and growth rate can affect meat texture, the predominant factor in determining muscle texture is the presence of the connective tissue protein collagen (Bailey and Light, 1989). Collagen fibers are important constituents of the extracellular matrix (Monnier et al., 1989). Total collagen (Mitchell et al. 1928), heat soluble collagen (Hill, 1966), and the degree of collagen crosslinking (Shimokomaki et al., 1972) influence tenderness.

Changes in collagen properties with age include a reduction in solubility, elasticity, and collagenase digestibility, and these changes are thought to be associated with increased crosslinking between collagen molecules. However, it is the quality of collagen, and not the quantity, that is critical. The collagen quality is determined by its thermal properties during heat denaturation (Bailey, 1990). When collagen is heated, it shrinks sharply at about $65^{\circ} \mathrm{C}$ to a weaker elastic polymer. The nature of the crosslinks determines its solubility and the extent of shrinkage. The older the animal is, the higher is 
the proportion of heat stable cross-links that hold the collagen chains together. As a result there is an increase in meat toughness (Bailey, 1989).

Formation of stable covalent crosslinks in collagen involves enzymatic and nonenzymatic processes. In the enzymatic process, collagen is stabilized by intramolecular (aldimine) and intermolecular (oxo-imine) reducible cross-links, which act as precursors of more stable mature cross-links. These cross-links can progress to multivalent crosslinks that result in a three dimensional network and polymerization of collagen fibers, thereby providing muscles and other tissues with the necessary mechanical strength (Bailey et al., 1974). During maturation, the proportion of the reducible aldimine and ketoamine crosslinks slowly reduce during maturation to low levels with increased non-reducible mature cross-links characteristic of mature collagen (Bailey et al., 1974), The final level depends on the ultimate turnover rate of that particular tissue protein. As the animal increases in age, collagen crosslinking is progressive, and the thermally labile, reducible aldimines (dihydroxylysinonorleucine, DHLNL; hydroxylysinonorleucine HLNL), and intermediate cross-links are converted into the thermally stable, mature nonreducible cross-links pyridinolines (hydroxylysylpyridinoline, HP; lysylpyridinoline, LP) (Avery et al., 1996, McCormick, 1994).

The relative proportion of these labile immature cross-links (DHLNL, HLNL) and stable mature pyridinoline crosslinks are important in determining the texture of cooked meat (Bailey \& Light, 1989; Bailey, 1990). Studies have been carried out to define a relationship between the extent and the nature of the cross-links and meat texture. Shimokomaki et al. (1972) have shown that increased heat stable crosslinks is concomitant with an increase in maturity of the animal and is related to increased meat 
toughness. Meat from young and old animals differs distinctly in tenderness, although their muscle collagen contents differ only slightly (Augustini and Temisan, 1985). The maturation process in the connective tissue results in these differences in muscle texture (Bosselmann et al., 1995). Stabilization of mature collagen is manifested through decreased solubility (Cross et al., 1984), increased mechanical stability (Bernal and Stanley, 1987), and resistance to enzymatic degradation (Weiss, 1976).

The non-enzymatic pathway proceeds through the Maillard reaction. In this process glucose, or other reducing sugars, react to form a Schiff base with $\varepsilon$ - or $\alpha$-amino groups of a number of proteins such as collagen, elastin, fibronectin, and lens crystalin, myelin (Harding, 1985). The product of this reaction then undergoes an Amadori rearrangement to yield a stable but still chemically reversible Amadori product (ketoamine). Additional reactions may take place that over time rearrange to form a class of colored and fluorescent products called advanced glycosylation end products (AGEs) represented mainly by carboxymethyllysine (CML) and pentosidine (Ps). These products remain irreversibly bound to macromolecules, accumulate, and can covalently crosslink to other molecules, leading to the structural and functional deterioration of tissue function (Bucala et al., 1992; Bailey et al., 1989; Monnier et al., 1981). While nonenzymatic glycation occurs on many proteins, collagen glycation is of particular significance.

Collagen, because of its long half-life, usually measured in years (15 years in skin), allows sufficient time for the accumulation of enough AGEs to alter the physical properties of the molecule (Reiser, 1998). Avery et al. (1996) reported that the amount of pentosidine in the longissimusus lumborum of the pig was associated with age-related changes in collagenous tissues. However, many investigators agree that extensive protein 
crosslinking probably contributes to the stiffening and loss of elasticity, characteristic of aging tissue (Cerami et al., 1985).

Post-translational modifications of collagen are associated with decreased solubility (Brownlee et al., 1986) and increased fluorescence, thermal stability and mechanical strength (Andreassen et al., 1981). It is hypothesized that non-enzymatic collagen crosslinking in muscle may contribute to the decline in meat tenderness of aged animals; although, its importance in skeletal muscle has not been established (Bailey, 1989; Klandorf et al., 1996).

Because AGEs may form by a pathway involving reactive $\alpha$-dicarbonyl intermediates (Chen et al., 1993; Bucala et al., 1992), a new class of cross-link breakers for AGEs were developed in order to cleave the carbon-carbon bond between the two carbonyls of a covalent glucose-derived protein cross-link (Vasan et al., 1996). One of these AGEs cross-link breakers is ALT-711, which is the stable phenyl-4,5dimethylthiazolium chloride, which is a derivative of the prototype $\mathrm{N}$ phenacylthiazolium bromide (PTB), (Vasan et al., 1996).

The aim of this study is to determine changes in the solubility of intramuscular collagen and tenderness of muscles as chronological age increases. In addition, this study will address the hypothesis that administration of the crosslink breaker ALT-711 to aged cattle will reverse the age related effect of crosslinks accumulation on mature collagen, thereby increasing collagen solubility of muscles and improving meat tenderness. 


\section{Literature Review}

Aging is a biological process that results in a progressive loss of tissue and organ function. Even though there is a vast literature describing the morphological, physiological, mechanical, and biochemical changes associated with connective tissue aging, the underlying mechanism responsible for the decline in function is still not well understood (Reiser, 1991; Reiser et al., 1992).

In some tissues, cross-links generated by the enzyme lysyl oxidase accumulate with age, and may in part account for the physicochemical changes in collagen crosslinking associated with aging (Yamauchi et al., 1988; Reiser et al., 1987). In addition, it is known that some age associated changes in the properties of collagen result from cross-links derived from nonenzymatic glycated residues (Reiser, 1991).

The glycation hypothesis of aging proposes that modification of proteins by glucose and the associated browning or Maillard reaction leads to the gradual crosslinking, polymerization, and fluorescence characteristics of aging in long lived proteins (Cerami, 1985; Monnier, 1989; Cefalu et al., 1995). However, biological aging is viewed as an organism's failure to maintain homeostasis (Holliday, 1992).

\subsection{Collagen and striated muscles}

Collagen is a major connective tissue protein that accounts for approximately $30 \%$ of the total protein contained in a mammalian body. Up to 19 different forms of collagen have been identified and associated with a variety of biological functions (McCormick, 
1999). Collagen structure varies from the mesh-like network of Type IV (basement membranes) to the long fibrous rod-like collagen fibers of Type I, II, III, and Type V (Nimni and Harkness, 1988; Bailey et al., 1998). Type I and Type III collagen are the primary forms of collagen molecules found in the extracellular matrix of muscle while Type V and Type IV collagen are associated with the endomysium and basement membrane of muscle, respectively (Bailey and Light, 1989).

Morphologically, muscle contains collagen in the epimysium, perimysium, and endomysium. The epimysium is the connective tissue sheath that surrounds individual muscles and joins a muscle to other muscles or to bones. Epimysium is composed predominately of Type I collagen and Type III in lesser amounts, and it is thick, tough and resistant to shear and solubilization. For this reason it is usually separated from meat cuts (McCormick, 1999). The three dimensional network that surrounds a muscle bundle fiber is the perimysium which is a mixture of Type I and Type III collagen (McCormick, 1999; Avery et al., 1996). Endomysium is the layer of connective tissue that encircles the individual muscle fiber, and it consists of Type V layered over a network of fibers containing Type III collagen (McCormick, 1999; Bailey et al., 1979).

Intramuscular connective tissue (IMCT) is a combination of $90 \%$ perimysium and $10 \%$ endomysium; consequently the perimysium may play an important role in determining meat quality (Light et al., 1985). Type I and III collagen proportions in muscles and their relationship to meat texture have been investigated, but the results were not conclusive and often contradictory (McCormick, 1994). Bailey et al. (1979) reported that increased proportions of Type III collagen in IMCT were associated with tougher muscles, while Light (1987) reported no changes. However, a significant difference 
between Type I and III collagen is the presence of disulfide-bonds in Type III, unlike the other fibrillar collagens (Bailey et al., 1979). Type III collagen is considered to be of embryonic origin. Neonatal or embryonic tissues are rich sources of Type III collagen. In most tissues including skeletal muscles, there is a general shift with chronological aging to increased proportions of Type I collagen (McCormick, 1994). However, the relationship between the proportion of Type I and Type III collagen and muscle tenderness of different muscles is prone to variation. Fiber size of different collagen types and intermolecular crosslinking are factors that may play roles in muscle tenderness rather than the relative proportion of Types I and III collagen (Burson and Hunt, 1986).

The collagen content of muscles is about $2 \%$ or less, but it can reach $4-6 \%$ in high connective tissue muscles (Lawrie, 1985, Casey et al., 1985). Even though collagen content of muscles is low (1-4\% of dry matter) compared to skin, bone and cartilage, in muscles plays a major role in determining the textural properties of meat (Bailey, 1988; McCormick, 1989). McAnulty and Laurent (1987) examined the collagen synthesis and degradation in vivo on various tissues of adult rat. In skeletal muscle synthesis rate was lower (2.2\%) compared to skin (4.2\%), heart (5\%), and lung (9\%).

\subsection{Collagen biosynthesis and cross-linking}

\subsubsection{Collagen biosynthesis}

The structural and fibrous protein collagen is synthesized in all type of cells and is deposited extracellularly in all tissues (Kanunga, 1980). Collagen biosynthesis is a multistep process associated with intracellular and extracellular events, as well as enzymatic 
post-translational modifications. Many of these post-translational modifications are unique to collagen.

During collagen synthesis on the rough endoplasmatic reticulum (RER), selected proline and lysine residues are enzymatically hydroxylated with the formation of hydroxyproline (Hyp) and Hydrolysine (Hyl). Hydroxylation of these residues involves the participation of prolyl and lysyl hydroxylase enzymes. These enzymes require ascorbic acid, ferrous iron $\left(\mathrm{Fe}^{+2}\right)$ and alpha-ketoglutarate $(\alpha-\mathrm{KG})$ as substrate. In addition to intracellular lysine hydroxylation, some hydroxylysine residues are glycosylated (McCormick, 1989).

The basic structural unit of collagen molecules is tropocollagen and consists of three polypeptide subunits called $\alpha$-chains intertwined to form a right-handed superhelix. Each $\alpha$-chain is approximately 1050 amino acids long, consisting of the repeating tripeptide sequence (Gly-X-Y), where $\mathrm{X}$ is frequently proline and $\mathrm{Y}$ is 4-hydroxyproline and may represent $30 \%$ of the residues, with glycine at every third position. The tropocollagen is about $300 \mathrm{~nm}$ long and $1.4 \mathrm{~nm}$ in diameter. The triple helix is a structure that forms in order to accommodate the unique composition and sequence of collagen. After the triple helix is formed intracellularly, it is transported into the extracellular environment. During its transport into the extracellular space, the terminal telopeptides are cleaved proteolytically, and disulfide bonds are formed.

In the extracellular space, collagen molecules assemble via hydrophobic and electrostatic interactions in a head-to-tail fashion with subsequent formation of a gap of $30 \mathrm{~nm}$ between adjacent collagen molecules. The result of this organization is the formation of microfibrils (McCormick, 1989; Karungo, 1980). Further, collagen 
molecules aggregate laterally into fibrils, with a pattern of five molecules to each row (pentafibril). Each collagen molecule overlaps adjacent collagen molecule by approximately one-quarter if its length, giving collagen fibrils a quarter-staggered pattern (Nimni and Harkness, 1988). The gaps and overlaps alternate with each other, and appear as light (gap) and dark (overlap) bands of collagen fibrils when viewed under an electron microscope (Karungo, 1980). Characteristics of collagen such as tensile strength, thermal stability, and degree of solubility are a function of collagen synthesis and its modifications after synthesis (McCormick, 1999).

\subsubsection{Collagen hydroxylation}

Intracellular post-translational modification of collagen occurs before triple helix formation and involves proline residue hydroxylation that stabilizes the triple helix. Proline hydroxylation is a key regulatory factor in collagen triple helix stabilization (Kanungo, 1980). In addition to proline hydroxylation, lysine hydroxylation is also important for extracellular interchain covalent, crosslink formation. Also, the hydroxylysine residue is necessary for glycosylation reactions. The enzyme responsible for lysine hydroxylation is lysyl hydroxylase and it requires ascorbic acid for its activity (Kanungo, 1980). Scurvy is an example of dietary vitamin C deficiency and involves the inability of collagen fibrils to form properly.

Galactosyl transferase and glucosyl transferase are the enzymes responsible for lysine glycosylation. The degree of proline and lysine hydroxylation and hydroxylysine glycosylation in collagen molecules types is as follows: Type III > Type II > Type I (Kanungo, 1980). The role of glycosylation in collagen synthesis is not completely 
known, but it may facilitate participation in non-enzymatic crosslinking reactions and that be related to collagen stability (Kanungo, 1980; Brodsky et al., 1988). The specific hydroxylation of lysine residues governs the collagen crosslinks and the biochemical properties of a tissue. For example, a deficiency of lysine hydroxylation results in collagen fibre fragility; an example of this deficiency is the heritable Ehlers-Danlos syndrome (EDS) (Bailey et al., 1998).

\subsection{Types of collagen crosslinking}

The most dramatic changes in collagenous tissues with age involve polymerization in the fibre through inter-molecular cross-linking (Bailey et al., 1998). Formation of crosslinks was first demonstrated by Verzar (1964) and involves two different mechanisms; one is enzymatically controlled during development and maturation that results in the formation of divalent products maturing spontaneously into stable multivalent crosslinks. Reduced metabolic collagen turnover allows the second indirect non-enzymatic mechanism to occur in association with maturation of tissue. This additional non-enzymatic crosslinking involves glycation and it is the major cause of collagenous tissue dysfunction in old age (Bailey et al., 1998). Although collagen crosslinking occurs extracellularly, this type of cross-linking depends on intra-cellular post-translational modifications, particularly lysine hydroxylation. The extent of lysine hydroxylation varies greatly between collagen types and tissues (Bailey et al., 1998). 


\subsubsection{Collagen crosslinking}

Collagen fibril tensile strength and functionality are due to formation of covalent intra- and inter-molecular crosslilnks. Crosslinking is initiated upon fibril formation by oxidative deamination of lysine and hydroxylysine residues via lysyl oxidase resulting in the formation of peptidyl aldehydes (allysine or hydroxyallysine). Two major pathways are known through which enzyme-mediated, lysine-aldehyde crosslinks form in Type I and Type III collagen.

The allysine pathway involves formation of aldimine crosslinks (dehydrohydroxylysino-norleucine, deH-HLNL; dehydro-lysinonorleucine, deH-LNL) from lysine aldehydes (Bailey et al., 1998). The hydroxyallysine pathway results in ketoimine crosslink formation (hydroxylysino-5-ketonorleucine, HLKNL;

dihydroxylysinonorleucine, DHLNL) from hydroxylysine aldehydes (Bailey et al., 1998; McCormick, 1999). These crosslinks vary in their stability, with ketoimine crosslinks being heat stable and aldimine heat labile (Allain et al., 1978).

Reducible crosslinks tend to disappear from many tissues in a time-dependent manner, with replacement by mature, non-reducible crosslinks (Bailey and Shimokomaki, 1971). Eyre (1981) postulated that the mature pyridinoline trifunctional cross-link is formed from condensation of the immature ketoimine cross-link (HLKNL) and hydroxylysyl aldehyde. Bailey and colleagues (1971) found that concentrations of reducible crosslinks decreased with age in human and bovine skin. This finding suggests that these mature pyridinoline crosslinks are stable and may explain the increase in insolubility and strength of older collagenous tissues. Compared to other tissue such as lung (Last et al., 1989) skeletal muscles, DHLNL and HLKNL reducible crosslinks are 
rapidly replaced with mature non-reducible pyridinoline crosslinks (hydroxylysylpyridinium (HP) and lysyl-pyridinium (LP)) (McCormick, 1999). McCormick (1994) found that in 1-year old steers, the concentration of crosslinks HP (moles HP/ mole collagen) in IMCT is more than two fold greater than its ketoimine DHLNL cross-link precursor.

Hydroxylysyl-pyridinium concentration increases with age. McCormick (1994) reported that the HP concentration in longissimus dorsi (LD) of a 5-year-old white-tailed deer is about $0.65 \mathrm{~mol} / \mathrm{mol}$ collagen, which is the highest recorded value for mammalian skeletal muscles. Zimmerman et al. (1993) reported that locomotor muscles possess more crosslinking than postural muscles, due to interaction between crosslinking and muscle collagen concentration. McCormick (1999) found that in less tender muscles, such as biceps femoris $(\mathrm{BF})$ and semimembranousus (SM), collagen concentration is about $3 \%$ of muscle dry weight and the level of HP is about $0.5 \mathrm{~mol} / \mathrm{mol}$ collagen. However, in the $\mathrm{LD}$, collagen concentration is $1.86 \%$ and is less crosslinked, with a HP concentration of $0.36 \mathrm{~mol} / \mathrm{mol}$ collagen. The steady increase in mature collagen crosslinking is due to progressive and ongoing crosslinking that occurs within fibrillar collagen as collagen synthesis slows when animals reach maturity (McCormick, 1994). A muscle effect on crosslink concentration is also reported. Muscles with high concentration of collagen (biceps femoris, soleus) that are also slow-twich, possess higher reducible and nonreducible cross-links than muscles of lower collagen content (Shimikomaki et al. 1972, Horgan et al., 1991). 


\subsubsection{Enzymatic collagen crosslinking: lysyl oxidase's role}

Enzymatic collagen crosslinking is mediated by lysyl oxidase. Crosslinking begins with oxidative deamination of specific lysine and hydroxylysine residues and subsequent formation of peptidyl aldehydes known as allysine and hydroxyallysine. The head-to-tail lateral alignment of collagen molecules allows lysine-, or hydroxylysinederived aldehydes, to react with other peptidyl aldehydes or unmodified lysine or hydroxylysine residues on adjacent molecules. This allows the formation of divalent and trivalent crosslinks such as ketoimines and pyridinium, respectively (McCormick, 1999).

Lysyl oxidase requires $\mathrm{Cu}^{2+}$ for its activity, and is one of the key regulatory factors in collagen crosslinking, since to date it is the only known enzyme involved in collagen crosslink formation (McCormick, 1999). Lysyl oxidase activity is influenced by hormones, environmental, and nutritional factors. Moreover, functional activity can vary as much as 10-fold in response to dietary copper (Tinker and Rucker, 1985).

Inhibition of lysyl oxidase during copper deficiency and lathyrism at critical stages in the developmental expression of connective tissue proteins can have dynamic and important biological effects. Extreme fragility of connective tissues due to the reduction in crosslinking results (Reiser et al., 1992). Lathyrism is a serious and debilitating disease occurring due to lysyl oxidase inactivation by $\beta$-aminopropionitrile, which is present in large amounts in sweet pea. Formation of intramolecular crosslinks in collagen is prevented, causing abnormalities in joints, bones, and blood vessels (Garrett and Grisham, 1999).

Variations in lysyl oxidase activity may play a role in determining the number of crosslinks, even though this hypothesis has not been directly investigated in muscle tissue 
(McCormick, 1994). The activity of lysyl oxidase decreases with age although the rate depends on the specific tissue (Sanada et al., 1978; Quaglino et al., 1993).

\subsection{The Maillard reaction and collagen crosslinking}

The Maillard or browning reaction refers to the non-enzymatic reaction between carbohydrates and amino group on tissue proteins, extending to the formation of irreversible chemical modifications of proteins known as advanced glycation endproducts (AGEs) (Thorpe and Baynes, 1996). Maillard reactions have become the central theme in a number of hypotheses to explain the relationship between reducing sugars such as glucose, and several age-related and diabetic pathologic conditions (Cerami, 1985).

Nonenzymatic glycation occurs on many proteins, but collagen glycation is of particular significance because of the exceptionally long half-life of collagen; in skin its half-life is 15 years, whereas in cartilage it is 117 years (Verzijl et al., 2000). This long half-life allows time for post-translational modifications and for accumulation of enough AGEs to alter the proteins properties. Verzijl et al. (2000), by studying collagen in articular cartilage and skin, demonstrated that protein turnover is a major determinant of AGE accumulation in these types of collagen.

Glycation affects collagen properties such as optimal biochemical functioning and the ability to form precise supra-molecular aggregates. Glycation alters charge distribution and collagen's interactions with cells. However, glycated collagen can act as an oxidizing agent (Bailey et al., 1998; Reiser, 1998). 
The most damaging effects of glycation are believed to be caused by formation of glucose-mediated inter-molecular crosslinks that decrease the flexibility and permeability of tissues and reduces the turnover rate of proteins (Bailey et al., 1998). Formation of intermolecular crosslinks and accumulation of glycation products on collagen is consistent with the decline of retinal capillaries, renal glomeruli, and arterial vessel walls, each of which is characteristic of ageing (Bailey et al., 1998; Brownlee et al., 1985). However, glycation depends on many tissue variables such as species, age of the organism, and diet (Reisser, 1998). Enzymatic and non-enzymatic collagen crosslinks are illustrated in Figure 2-1.

Glycation of tissue protein and subsequent AGEs formation have been implicated as mediators of the aging process and of the development of long-term complications seen in diabetic subjects such as cardiovascular disease, retinopathy, nephropathy, and joint stiffness (Cerami, 1985; Brownlee et al., 1988; Monnier, 1989).

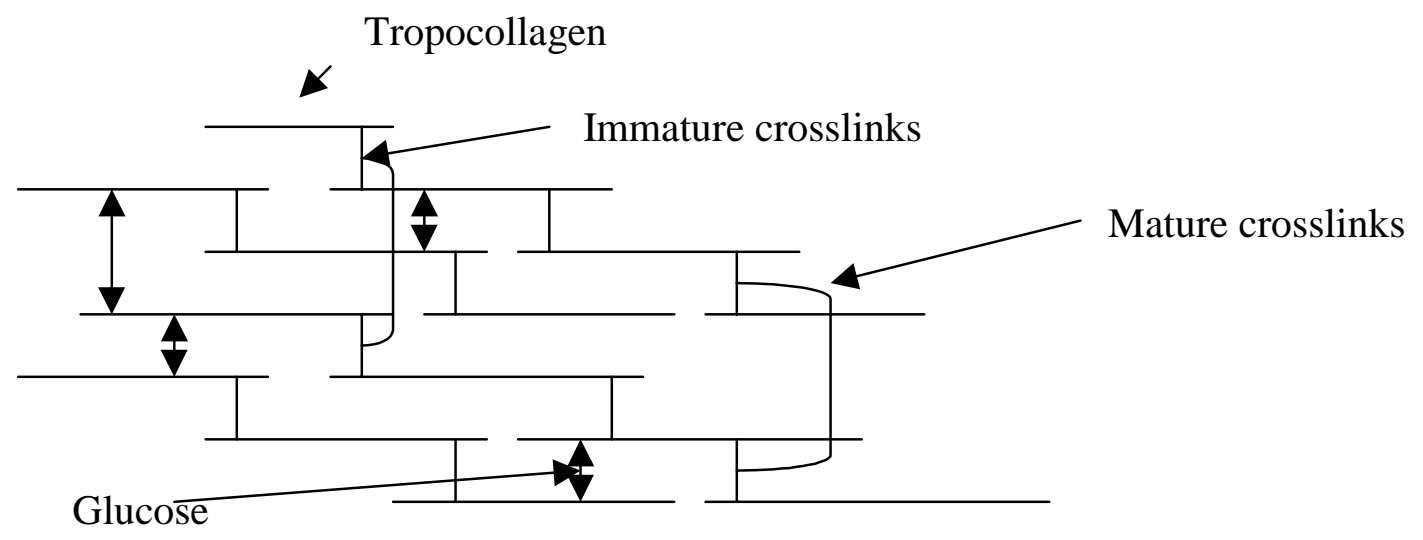

Derived crosslinks

Figure 2-1. Schematic illustration of mature, immature and glucose derived cross-link formation on collagen molecules. (Adapted from Bailey et al. 1989). 


\subsection{Advanced glycation end-products and extracellular matrix changes}

Non-enzymatic glycosylation and its biological significance have been studied primarily in long-lived proteins like collagen, lens crystallins, myelin and hemoglobin (Syrovy and Hodny, 1992). Glycation is a complex process in which glucose or other reducing sugars react with $\varepsilon$ - or $\alpha$-amino group of collagen or other proteins to form an aldimine or Schiff base. The product of this reaction undergoes Amadori rearrangements to form stable and chemically reversible Amadori products (ketoimines). The Schiff base and the ketoimine undergo additional reactions with other amino acid residues (Cerami et al., 1987) or metal ion induced oxidation to form advanced glycation end-products (AGEs).

In addition to these pathways of AGEs formation, intra-molecular rearrangement of Amadori products by isomerization forms $\alpha$-ketoaldehydes such as 3-deoxyglucosone, which is a highly reactive dicarbonyl compound (Chappey et al, 1997). Over time and through additional reactions, flourescent advanced glycosylation end products are formed and the proteins crosslinking results in a yellow-brown pigmentation with fluorescence spectrum (Monnier and Cerami, 1981; Chappey et al., 1997).

It has been demonstrated (Chappey et al., 1997; Cagliero et al., 1991) that AGEs accumulate on vascular wall collagen and basement membrane proteins as a function of age and glycemia. Collagen, in addition to its structural role, provides a functional matrix with which a variety of cell types interact (Paul et al., 1999). Brownlee (1995) showed that glycation modifies structural and functional properties of matrix components. On Type I collagen, crosslinking induces an expansion of molecular packing. Formation of 
AGEs on type IV collagen inhibits lateral association of the molecules into a normal network-like structure.

Advanced glycated proteins have reduced susceptibility to protease digestion (Chappey et al., 1997) and they have altered mechanical and thermal properties (Reiser, 1990). Collagen AGEs formation results not only in the formation of inter-molecular crosslinks and side chain modifications, but also in changes of cell-collagen interactions (Bailey et al., 1998; Reiser, 1991).

\subsection{Muscle development}

\subsubsection{Cellular events}

Skeletal muscle growth is a complex process that involves many physiological processes and factors (Dodson et al., 1996). Two biological processes accomplish skeletal muscle growth: cell proliferation and protein accretion.

Protein accretion is a function of protein synthesis and degradation. Cell proliferation can occur prenatally and postnatally (Allen et al., 1979). In the early stages of muscle development, mesodermal stem cells give rise to the embryonic myoblast. Myoblast proliferate and subsequently withdraw from the cell cycle into a protracted G1 or $\mathrm{G}_{0}$ phase, and muscle specific genes are activated. Myoblasts, that have withdraw from the cell cycle, fuse to form multinucleated myotubes. The primary and secondary myotubes synthesize myofibrillar proteins that assemble as myofibrils (Smith and Doumit, 1999).

Postnatal skeletal muscle growth involves: DNA accumulation and protein accretion. Winick and Noble (1966) reported a 8.5-fold increase in rat muscle DNA from 
age 21 to 133 days. Muscle cell DNA increases substantially during postnatal life, which coincides with the rapid period of muscle growth (Allen et al., 1979). Skeletal muscle size is directly proportional to muscle DNA content. Allen et al. (1979) reported that 50$88 \%$ of total DNA accumulates postnatally in mammals. Mauro (1961) demonstrated that the newly synthesized DNA is provided by a population of myogenic (Bischoff, 1974), mononucleated cells called satellite cells that are situated beneath the basement membrane of muscle fibers. When these cells proliferate, one daughter cell fuses with the muscle fiber and muscle protein synthesis occurs (Allen et al., 1979). Myogenic cell proliferation is a regulatory factor controlling muscle growth. (Allen et al, 1979).

Skeletal muscle protein accumulation occurs when protein synthesis exceeds degradation. In all species, fractional protein synthesis and degradation rates are high in young animals and decline in older animals, while fractional accretion of muscle protein decreases with age (Smith and Doumit, 1999). Textural changes that occur in meat as animals grow and mature are correlated with the progressive maturation of collagen (Smith and Doumit, 1999).

\subsubsection{Muscle histochemistry}

Differences in muscles within species may reflect differences in muscle fiber type. Mammalian skeletal muscle is composed of a mixture of: slow-twitch oxidative, fasttwitch oxidative-glycolytic and fast-twitch glycolytic (Peter et al., 1971). Brooke and Kaiser (1970b) used histochemical methods these fiber types are designated as Type I, Type II A, and Type II B, respectively or Type $\beta-\mathrm{R}$ (red), Type $\alpha-\mathrm{R}$ (intermediate) and Type $\alpha-\mathrm{W}$ (white) by Ashmore et al. (1971). 
The differentiation of muscles as "red" or "white" is based on the content of individual red and white fibers. Fiber type differences influence growth rate and postmortem carcass characteristics such as rigor mortis onset, $\mathrm{pH}$ decline, color, and tenderness (Smith and Doumit, 1999). The "red" muscles tend to have a greater proportion of narrow, myoglobin, and mitochondria rich fibers. These fibers are supplied by many blood capillaries and have a greater respiratory activity. The "white" muscles are glycolytic in their metabolism and have an increased number of broad, myoglobin, and mitochondria poor fibers. Intermediate fibers resemble red fibers, having a larger diameter and a narrow Z-line. Because of oxygen requirements of "red" muscles, glycogen reserves tend to be less and the ultimate $\mathrm{pH}$ is higher than that of "white" muscles (Lawrie, 1991). Red muscles also have a lower content of calcium-activated sarcoplasmic factors (CASF). Goll et al., (1974) reported that CASF are responsible for disintegration of essential structural elements of the myofibril during conditioning, which may explain why red muscles tenderize less markedly than white muscles. Koohmaraie et al., (1988) found that the biceps femoris (slow-twich) had a lower level of calpains and ages less than longissimus dorsi.

\subsection{Factors affecting cross-links formation in muscle tissue}

Factors that influence molecular and biochemical processes responsible for the variation in collagen characteristics are not well understood (Reiser et al., 1992; McCormick, 1994). Variations in lysyl oxidase activity may play a role in determining the number of cross-links (McCormick, 1994). Level of lysine hydroxylation influences 
crosslinking patterns (Henkel et al., 1987). Variability in lysine hydroxylation among collagen types and between different tissues has also been established (Resier et al., 1992).

\subsubsection{Age and Growth}

Changes in the physical properties of collagen during aging are reflected in increased stiffness of skin, tendon, bone, joints, and also an increase in tissue rigidity (Torp et al., 1975).

The composition of muscles varies with increasing age eventhough the rate in increment is not identical for all muscles. Changes that occur in muscles as animals grow and mature are correlated with progressive maturation of muscle collagen (Lawrie, 1991). For example, McCormick (1989) and Andersen et al. (1992) found that the hydroxypyridinoline concentration in different species and muscles increases with age. The concentration of non-reducible crosslinks of longissimus dorsi muscle from sheep and deer less than a year old are already $50 \%$ or more of the values for mature animals that are 5-7 years old (McCormick, 1994). The steady increase in mature collagen crosslinking is due to progressive reactions that occur within fibrillar collagen in contrast to the decline in the rate of collagen synthesis as the animals reach maturity. Less collagen synthesis and turnover provide existing fibrillar collagen time to progressively crosslink or mature (McCormick, 1994). Cross et al. (1973) and Hiner and Hankins (1950) reported a negative correlation between chronological age and tenderness. Shimokomaki et al. (1972) and Horgan et al. (1991) found that muscles with higher 
concentrations of collagen such as biceps femoris, which is also slow-twitch, contain more reducible and non-reducible crosslinks than muscles with less collagen.

Collagen concentration in skeletal muscle varies little with growth and aging; although, some exceptions exist, such as elevated collagen concentrations in the muscle of young animals (Andersen et. al., 1992) and diminished concentrations in the muscles of double-muscled cattle (Bailey et al., 1989). Also, collagen concentration in muscle varies with the sex of the animal; intact males contain more collagen in their muscles compared to castrates (Miller et al., 1989).

\subsubsection{Growth rate and animal duration on concentrate diet}

It is generally agreed that, for maximal tenderness, the best time to slaughter animals is after a period of rapid growth (Etherington, 1987).

A high plane of nutrition and rapid growth results in greater collagen synthesis. The pool of new collagen (less crosslinked, more soluble and heat labile) is assumed to dilute the older existing collagen, thus resulting in more tender muscles (Etherington, 1987). Aberle et al. (1981) and Fishell et al. (1985) found that steers slaughtered at the same age but grown at different rates resulted in differences in meat tenderness.

Slower growth rates were associated with lower muscle tenderness scores, less soluble collagen, and slightly higher total collagen. Similar results were obtained by Miller et al. (1987) when muscle and collagen characteristic of mature cows fed a high energy diet were compared to those on a maintenance energy diet. However, Wu et al. (1981) reported no differences between steers fed high-energy or roughage diets. Feeding concentrate diets for a period of time prior to harvest will improve tenderness of steaks 
from growing cattle (Coleman et al., 1995). Cranwell et al. (1996) reported that feeding a high concentrate diet for 28 days enhanced carcass quality characteristics (lean color, sensory traits, Warner-Bratzler shear values). Tatum et al. (1980) and Aberle et al. (1981) found that tenderness improves when feeding high-energy diets for 30 days, but others (Hedrick et al., 1983; Larick et al., 1987) found that maximum tenderness required longer feeding time (Van Koevering et al., 1995). This effect is likely associated with changes in collagen properties such as increased percentage of soluble collagen. However, the effect of extended feeding on tenderness may be an indirect response to an increase in subcutaneous fat resulting in decreased carcass chilling that is due to fats insulatory properties (Owens and Gardner, 1999).

\subsubsection{Rapid or Compensatory Growth}

Laurent et al. (1978) and Sparrow (1982) reported that, during stretch-induced growth in chicken skeletal muscle, total collagen content of muscle increased, but not at the same rate as non-collagen intracellular protein. However, intracellular collagen synthesis (perimisyum and endomysium) was at same level as non-collagen protein with an overall decrease in total collagen due to decreased synthesis of epimysial collagen (Laurent et al., 1978; Sparrow, 1982; McCormick. 1989). During hypertrophy of the

lattissimus dorsi of chicken (Laurent et al., 1985) collagen synthesis increased 5-fold while degradation of newly synthesized collagen decreased by half. Degradation of mature collagen increased about 4-fold; this degradation may have been due to breakdown of collagen containing covalent crosslinks though not necessarily mature crosslinks (Laurent et al., 1985). 
The mechanism of collagen turnover in rapidly growing (hypertrophying) muscle seems to differ from that in skin or tissue with normal or restricted growth (McCormick, 1989). Increased muscle size with growth, based on the results of Laurent et al. (1985) gave rise to the "remodeling" theory. Based on remodeling theory, increased collagen synthesis is accompanied by decreased degradation of newly synthesized collagen. However, the mechanism by which new collagen molecules integrate themselves among existing molecules is not known (Etherington, 1977, 1987; Etherington and Bailey, 1982).

\subsection{4 pH}

During muscles conversion to meat, anaerobic glycolysis results in lactic acif accumulation and thus a decline in $\mathrm{pH}$. The rate and the extent of $\mathrm{pH}$ decline are major determinants of meat quality. Numerous studies (Purchas et al., 1990; Watanabe et al., 1996) have shown that an increase in ultimate $\mathrm{pH}(\mathrm{upH})$ of longissimus thoracis muscle from 5.5 to 6.0 is associated with increased toughness. Warner (1994) and Pearson and Young (1989) reported that a higher upH is associated with darker color, reduced drip loss and increased firmness. One of the factors that influences $\mathrm{pH}$ is muscle glycogen level at death. However, muscles with the same lactate concentration may have different pH (Van Laack et al., 2000). Scopes (1974) reported that when glycogen is not limited, upH is influenced by the activity of glycogen phosphorylase and AMP deaminase enzymes. 


\subsection{Prevention of glucose-derived protein crosslinks}

When Verzar (1964) discovered the formation of crosslinks, the nature and the mechanisms of their formation was not known. However, after decades of research, the mechanism of cross-link formation was revealed and resulted in attempts to inhibit and even breakdown glycation cross-links, thus limiting the effects of AGEs during aging (Bailey et al., 1998).

\subsubsection{Physiological intervention}

An interesting concept, first proposed by Vlassara et al. (1985), is that the body itself has a mechanism to remove AGEs. Vlassara proposed that through AGE/receptor interaction, AGE modified proteins are chemotactic and can be removed by macrophages. It has been shown that the interaction of AGEs with cellular receptors induces secretion of interleukin-1(IL-1) and Tumor Necrosis Factor- $\alpha$ (TNF- $\alpha$ ). These observations suggest a regulatory system by which macrophages selectively remove AGE modified proteins and contribute to the repair and remodeling of body systems (Bailey, et al., 1998, Vlassara et al., 1985). Receptors capable of binding to glycation products have also been identified on monocytes, lymphocytes, endothelial cells, and fibroblasts (Reiser, 1998).

\subsubsection{Interventional strategies}

One of the initial strategies for decreasing the accumulation of glycation products consisted of blocking glucose adduct formation, based on assumption that Schiff baseAmadori products are precursors of most AGEs (Reiser, 1998). Many compounds have been shown to be effective at blocking glucose adduct formation in vitro, including 
aspirin, (Swamy et al., 1989), gluthatione (Huby and Harding, 1988), and acetic anhydride (Rendell et al., 1986). Giardino et al., (1995) have shown that Vitamin E prevents formation of intracellular, advanced glycation products in the arterial wall of streptozotocin (STZ) diabetic rats.

Another strategy for attenuating glyco-oxidative damage is diet restriction (DR), or done in combination with the crosslinking inhibitor aminoguanidine (AG) (Reiser, 1998; Iqbal et al., 1999a). Studies carried out on lifetime caloric restriction in mice (Reiser, 1994), monkeys (Cefalu et al., 1997) and broiler breeder hens (Iqbal et al., 1997) showed that caloric restriction significantly decreased in collagen fluorescence associated with the crosslinks, pentosidine (Ps) and carboxymethyllysine (CML).

\subsubsection{Pharmacological intervention on AGEs accumulation}

Rieser (1991) reported that non-enzymatic glycation of proteins, including collagen, may be initiated by various mechanisms such as Amadori product degradation, glucose auto-oxidation, and the polyol pathway. It is most likely that glycation products may form from different reactions.

Pharmacological intervention has been the most successful approach to inhibit

formation of glycation products and to cleave advanced glycation end products at various stages (Reiser, 1998). Pharmacological agents have been developed as potent inhibitors of glycation and AGEs formation, such as D-lysine, pyridoxamine, thiamine pyrophosphate, thiazolidine derivative OPB-9195, aminoguanidine, and aryl ureido- and aryl carboxamido phenoxy isobutiric acid (Rahbar et al., 1999). Aminoguanidine has 
been shown to inhibit the formation of advanced glycation products by binding to Amadori and glucose fragmentation products (Reiser, 1998).

Vasan et al., (1996) first reported the synthesis of a chemical capable of breaking glycation crosslinks. The novel cross-link "breaker", ALT-711, is the stable 4,5dimethylthiazolium derivative of the prototype compound N-phenylacylthiazolium bromide (PTB) that has been shown to break AGEs in vitro and in vivo (Wolffenbutel et al., 1998; Vasan et al., 1996). It had been reported by Wolffenbutel et al. (1998) and Asif et al. (2000) that treatment of diabetic rats and aged dogs with ALT-711 reversed the diabetes-induced increase of large artery stiffness and reduced, by $40 \%$, age-related left ventricular stiffness.

\subsubsection{ALT-711 mode of action}

The mechanism of ALT-711 assumes that the generation of covalent glucosederived protein crosslinks occurs through Amadori-product diones (AP-diones). This novel crosslink "breaker" reacts with glucose-derived protein crosslinks and cleaves the carbon-carbon bond of an AGE-derived protein crosslinks. It is proposed that at physiological $\mathrm{pH}$, the nucleophilic centers of the thiazolium-2 position and the $\alpha$-position of the N-substituent react with carbonyl group; a five-membered ring is formed, thus facilitating spontaneous cleavage (Vasan et al., 1996; Figure 2-2b). AP-diones are expected to be highly reactive in protein crosslinking because they are sites for the addition of amines (Lys, His-) or sulphydryl (Cys)- nucleophiles with the formation of stable Amadori product (AP) as shown in Figure 2-2a. 


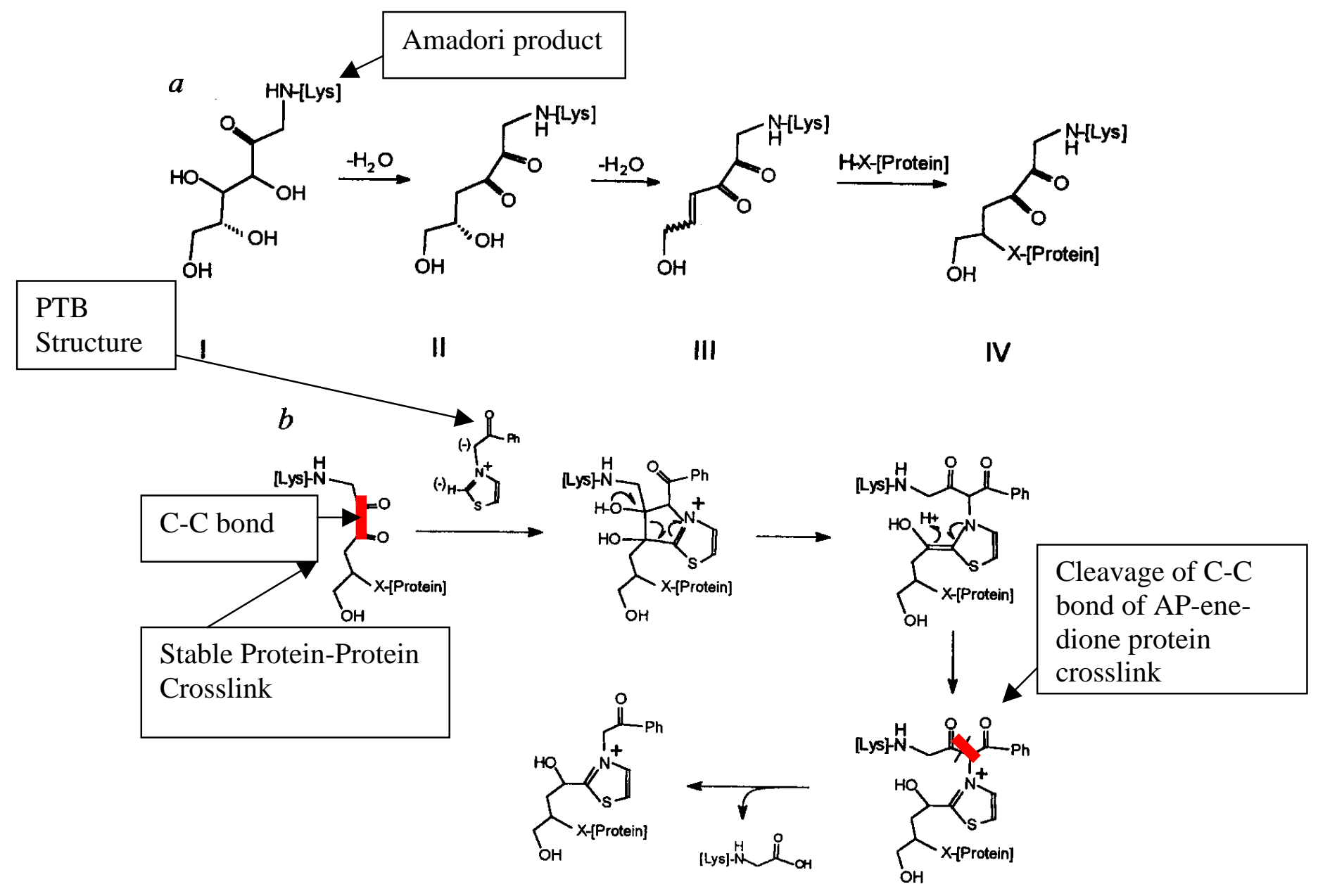

Figure 2-2. Scheme for the formation of glucose-derived protein crosslink from Amadori Product (a) and cleavage by thiazolium breaker (PTB) (b). I= Protein-bound (Lys) Amadori product (AP), II= AP-dione, III= AP-ene-dione, IV= Stable protein-protein crosslink, $\mathrm{PTB}=\mathrm{N}-\mathrm{Phenacylthiazolium}$ bromide. (Adapted from Vasan et al., 1996).

Vasan et al., (1996) showed that daily administration of PTB $(10 \mathrm{mg} / \mathrm{kg})$ by injection (i.p.) to established diabetic rats markedly reduced IgG bound to erythrocytes. Wolffenbuttel et al. (1998) showed that administration of ALT-711 to diabetic rats at a dose of $1.0 \mathrm{mg} / \mathrm{kg}$ body weight decreased pepsin solubility of tail tendon collagen compared to that measured in nondiabetic, control rats. There was also a dose dependent reduction in red cell surface $\operatorname{IgG}$ in treated rats. 
The age-related decline in meat tenderness, due to non-enzymatic glycosylation or glucose-collagen crosslinking may be ameliorated by ALT-711 crosslink breaker if administered to aged animals prior slaughter.

Whether the deleterious effects of glycation on muscles during normal aging or of accelerated aging associated with diabetes can be ameliorated with this compound, remains to be determined through more research. 


\section{Materials and Methods}

\subsection{Animals and Management}

Control and treatment groups: Mature cattle $(n=10)$ ranging from 8 to 11 years of age, were purchased and transported to the Animal Science Farm, West Virginia University. Animals were maintained for 4 weeks under standard husbandry practices. A $10.5 \%$ crude protein $(\mathrm{CP})$ diet was fed ad libitum prior to and during the experimental period.Treatments were randomly assigned to animals, and a group of two animals was formed $(n=2)$, and housed in the same pen. Five groups were formed and each group was maintained on diet as follow: group I, 67 days; group II, 95 days; group III, control 51 days, Alt-711 treated 101 days; group IV, 66 days; group V, 80 days. Control animals were injected with physiological saline $(0.9 \% \mathrm{NaCl})$, while treated animals were injected with ALT-711 (5mg/kg body weight) for a period of 28 days. Intramuscular injections were given in the neck (i.m.) on both sides, between 9-11 a.m. The dose ALT-711 was adjusted each week based on body weight of the previous week. Animals were individually weighed at weeks $0,1,2,3$, and 4 .

A-maturity group: Five crossbreed heifer (15-18) months were purchased and slaughtered over a period of two months.

Sampling and storage. One day prior to slaughter, the cattle were transported to the slaughter facility. Blood samples were collected on the day of slaughter. Hot carcass weights were recorded, and the carcasses were held for $48 \mathrm{~h}$ at $4^{0} \mathrm{C}$. Within $48 \mathrm{~h}$ muscles

from the right side were collected, trimmed, weighed, vacuum packed, and frozen at $-20^{\circ}$ 
$\mathrm{C}$ until analysis. Trunk blood samples were collected and kept on ice until centrifuged.

Plasma was harvested and frozen until required for analysis. The following muscles were collected:

round: Semimembranous, Semitendinous, and Biceps femoris

loin: Longissimus et lumborum

rib: Longissimus et thoracis

chuck: Supraspinatus, Triceps brachii (lateral, long, medial).

\subsection{Color determination}

Measurements were made by CIE $\mathbf{L}^{*} \mathbf{a}^{*} \mathbf{b}^{*}$ using Minolta Chromameter (Model CR-300, no. 82381003, Minolta Camera Co. Ltd., Japan) calibrated with white standard plate (no. 21333180, CIE: Y=93.1, x=. 3135, y=. 31981). Steaks were covered with PVC and left for blooming 30 minutes at $4{ }^{0} \mathrm{C}$ in the cold room and then three measurements were recorded on each steak. $\mathbf{L}^{*}$ indicates the lightness and darkness of a sample. A higher value indicates a lighter sample. $\mathbf{a}^{*}$ indicates red or green state of a sample, the higher the value the redder the product. $\mathbf{b}^{*}$ value indicates yellow or blue state of a sample. The higher the $\mathbf{b}^{*}$ value the more yellow sample.

\subsection{Warner-Bratzler Shear Force}

One steak from the middle section of each muscle was assigned for analysis. The steaks were thawed in a $4^{0} \mathrm{C}$ cold room for $24 \mathrm{~h}$, and then cooked on Farberware Open Hearth Electric Grill (Model no. 3240147, NY) according to AMSA procedures to a final 
internal temperature of $72^{\circ} \mathrm{C}$. The temperature was monitored with an Industrial Data Logger (Model 205, Beckman Industrial) equipped with a copper-constant thermocouple wire (Omega Technologies; Stamford, CT 06907). The copper-constant thermocouple was placed in the geometric center of each steak. When the steak reached the final end point temperature, they were cooled to room temperature (for 3-4 h), and cores $(1.27 \mathrm{~cm}$ diameter, 6-7 cores/steak) were removed using Drill Press Stand (Sears, Model 25921). Shear force (SF) was evaluated by using a Texture Analyzer (Model TA-HIS, Texture Technology, NY, 10583) equipped with Warner-Bratzler apparatus attached to a $50 \mathrm{~kg}$ load cell. Shear force measurements were performed at a crosshead speed of 124.8 $\mathrm{mm} / \mathrm{min}$, and the peak force was recorded using Texture Expert Software (Stable Micro Systems Ltd., 1997).

\subsection{Cooking loss}

Cooking loss (\%) was calculated as follow: (raw weight-cooked weight/raw weight)*100.

\subsection{Soluble and insoluble Collagen}

After the cores were removed, steaks were cleaned of visible fat and epimysium, placed in liquid nitrogen, frozen and powdered in a Waring Blender. Samples of $4 \mathrm{~g}( \pm 0.4$ g) powdered cooked muscle were analyzed for soluble and insoluble collagen according to the procedure of Hill (1967). The weighed sample was put into a $50 \mathrm{~mL}$ centrifuge tube and $12 \mathrm{~mL}$ Ringer solution (1/4 strength) heated to $50^{\circ} \mathrm{C}$ was added (Zepeda et al., 
1995). The tube was left in a bath water for $10 \mathrm{~min}$ at $50^{\circ} \mathrm{C}$ and then cooled at room temperature for 30 minutes. Tubes were centrifuged at $6000 \mathrm{xg}$ for 10 minutes at $4^{0}$. Eight $\mathrm{ml}$ of supernatant was removed and placed in test tubes and the remaining supernatant was discarded. To this pellet $8 \mathrm{ml}$ of $1 / 4$ strength Ringer solution was added, vortexed, centrifuged and the supernatant collected and added to the previous test tubes.

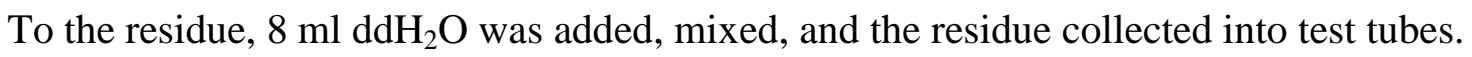
To the supernatant tubes, $12 \mathrm{ml} \mathrm{HCl}(12 \mathrm{~N})$ was added, while $8 \mathrm{ml} \mathrm{HCl}$ was added to the residue. Tubes were loosely capped and hydrolyzed for $18 \mathrm{~h}$ at $110^{\circ} \mathrm{C}$ in Autoclave. After cooling at room temperature, $500 \mathrm{mg}$ decolorizing carbon was added, the tubes were vortexed and filtered through Whatman Filter Paper no. 1. Hydroxyproline content was determined in the hydrosylates following the modified Stegman and Stadler spectrophotometric method (Maekawa et al., 1970). Collagen content was calculated from a hydroxyproline standard curve for each muscle samples analyzed. A convertion factor of 7.52 and 7.25 for soluble and insoluble collagen were used, respectively (Cross et al., 1973; Zepeda et al., 1995). Readings were performed at $564 \mathrm{~nm}$ using DUß Spectophotometer (Beckman Coulter ${ }^{\mathrm{TM}}$, USA) within 120 minute.

\section{6 $\mathrm{pH}$ measurements}

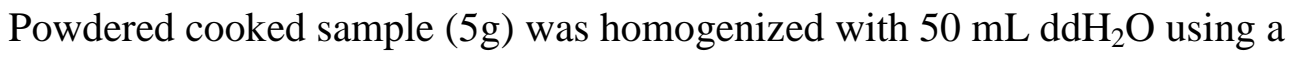
Laboratory Blender (Model Stomacker 400, Tekman, Cincinnatti, OH) for 30 seconds. $\mathrm{pH}$ was determined using a pH/ion analyzer (Model 350, Corning, NY) and generalpurpose combination electrode (Corning). The $\mathrm{pH}$ was recorded when the reading was stabilized. 


\subsection{Plasma Glucose}

Plasma glucose $(n=13)$ was analyzed using YSI Biochemistry Analyzer (Model \#2700, YSI Corp, OH). For each of the control and treated groups, plasma from one animal was not collected. Two readings were recorded for each sample, and the mean was used for the analysis of variance.

\subsection{Sarcomere length}

Measurement of sarcomere length was done according to the procedure described by Burson et al. (1980). Three cores $(1.27 \mathrm{~cm}$ in diameter) were removed from the central part of each steak. Cores were placed in a plastic bag, vacuum packed and stored at $-20^{0}$ $\mathrm{C}$ until analyzed. Cores were thawed for 1 hour at room temperature. The center of each core was removed, cut in 3 pieces and blended at low speed in a Waring Blender for 60 seconds with $60 \mathrm{~mL}$ of cold, $0.25 \mathrm{M}$ Sucrose solution. Images were acquired using light phase contrast microscopy (Zeiss Microscope, Broserser Instrument Co., Inc. PA) at x400, equipped with CoolSnap Camera (RS Photometrics, Serial no: A00B81079) and CoolSnap Software (Roper Scientific Inc., 1998-1999, Version: 1.2). Sarcomere length measurements were obtained using Image Analysis System, FluorChem ${ }^{\mathrm{TM}}$ Software (Alpha Innotech Corporation, Serial no: 800079). The mean sarcomere length of 10 sarcomeres/myofibre was recorded and 10 myofibres for each sample were measured. 


\subsection{Statistical Analysis}

Data were analyzed as a completely randomized design (CRD), using general linear model (GLM) procedure of SAS (SAS Institute, Inc., 1990). Least Significant Difference (LSD) test was used to determine the difference between treatment means $\left(\mathrm{p}<0.05^{*}\right.$ and $\mathrm{p}<0.10^{* *}$ ), also orthogonal comparison (F-test) was used to test linear contrasts Ematurity vs A-maturity and control vs Alt-711 treated groups. A regression analysis was performed to determine the simple Pearson correlation coefficient for longissimus thoracis muscle, $\mathrm{R}^{2}$, between total, insoluble, soluble collagen, soluble collagen percentage, fat thickness and shear force. Also Pearson correlation coefficient was determined between sarcomere length and shear force for longissimus thoracis and biceps femoris. Simple regression was used for relationship between: number of days on feed, and back fat thickness, age and shear force, age and soluble collagen.

\section{Results}

\subsection{Carcass}

Carcass characteristics for cattle in the control and ALT-711 treated groups are shown in Table 4-1 and 4-2 and for A-maturity group in Table 4-3. Cattle in treatment groups were classified as E-Maturity class (>96 months). The average maturity was 9.8, and 8.4, for control and ALT-711 treated groups, and 1.5 years for A-maturity group, respectively. Final body weights were as follows: for the control group $613 \mathrm{~kg}, 633 \mathrm{~kg}$ for ALT-711 treated group, and for A-maturity group $559 \mathrm{~kg}$. Hot carcass weights were $294 \mathrm{~kg}$ and $317 \mathrm{~kg}$, and muscle percentages were $8.7 \%$ and $8.6 \%$ for control and ALT- 
711 treated groups, respectively. Rib eye area was bigger for A-maturity animals compared to control and Alt-711 however not significant $(\mathrm{p}>0.10)$. Cattle gained weight during the treatment period, although the initial and the final body weights were not statistically different ( $>0.05$ ) between control and ALT-711 treated groups (Figure 4-1). However, ALT-711 treated animals had a higher $(\mathrm{p}<0.10)$ final body weight compared to A-maturity animals (Table 4-2).

Table 4-1. Carcass characteristics for the control group $(n=5)$.

\begin{tabular}{|llllll|}
\hline Traits & & Mean & S.E & Min & Max \\
\hline & & & & & \\
Age & $(\mathrm{yrs})$. & 9.8 & 0.37 & 9 & 11 \\
Initial wt. & $(\mathrm{kg})$ & $595^{\mathrm{a}}$ & 35.2 & 480 & 691 \\
Final weight & $(\mathrm{kg})$ & $613^{\mathrm{ab}}$ & 36.5 & 530 & 727 \\
Hot carcass wt. & $(\mathrm{kg})$ & 294 & 22.3 & 241 & 370 \\
Muscle wt. & $(\mathrm{kg})$ & 25.4 & 1.3 & 23.3 & 30.3 \\
Muscle \% of carcass & $(\%)$ & 8.70 & 0.29 & 8.20 & 9.80 \\
Adj. fat thickness & $(\mathrm{cm})$ & $0.86^{\mathrm{a}}$ & 0.25 & 0.13 & 1.52 \\
Rib Eye Area (REA) & $\left(\mathrm{cm}^{2}\right)$ & $69.80^{\mathrm{a}}$ & 4.37 & 61.29 & 86.45 \\
\hline
\end{tabular}

${ }^{\mathrm{a}-\mathrm{b}}$ Means for the same trait between groups with different superscript are different $(\mathrm{p}<0.10)$.

Table 4-2. Carcass characteristics for the ALT-711treated group (n=5).

\begin{tabular}{|llllll|}
\hline Traits & & Mean & S.E & Min. & Max. \\
\hline & & & & & \\
Age & $(\mathrm{yrs})$ & 8.4 & 1.36 & 3 & 10 \\
Initial wt. & $(\mathrm{kg})$ & $615^{\mathrm{a}}$ & 29.9 & 543 & 705 \\
Final wt. & $(\mathrm{kg})$ & $633^{\mathrm{a}}$ & 25.1 & 575 & 700 \\
Hot carcass wt. & $(\mathrm{kg})$ & 317 & 22.2 & 268 & 377 \\
Muscle wt. & $(\mathrm{kg})$ & 27.1 & 1.19 & 24 & 30 \\
Muscle \% of carcass & $(\%)$ & 8.6 & 0.26 & 8 & 9.3 \\
Adj. Fat thickness & $(\mathrm{cm})$ & $0.91^{\mathrm{a}}$ & 0.31 & 0.13 & 1.78 \\
Rib Eye Area (REA) & $\left(\mathrm{cm}^{2}\right)$ & $78.2^{\mathrm{a}}$ & 2.66 & 71.61 & 87.10 \\
\hline
\end{tabular}

${ }^{\mathrm{a}-\mathrm{b}}$ Means for the same trait between groups with different superscript are different $(\mathrm{p}<0.10)$. 
Table 4-3. Carcass characteristics for the A-maturity group ( $n=5)$.

\begin{tabular}{|llllll|}
\hline Traits & & Mean & S.E & Min & Max \\
\hline Age & & & & & \\
Final wt. & $(\mathrm{yrs})$ & 1.5 & 0.1 & 15 & 20 \\
Muscle wt. & $(\mathrm{kg})$ & $559^{\mathrm{b}}$ & 10.6 & 532 & 586 \\
Adj. Fat thickness & $(\mathrm{kg})$ & 22.4 & 0.9 & 20.1 & 25 \\
Rib Eye Area (REA) & $\left(\mathrm{cm}^{2}\right)$ & $1.1^{\mathrm{a}}$ & 0.17 & 0.51 & 1.5 \\
a & $80.5^{\mathrm{a}}$ & 6.2 & 61.3 & 98.7 \\
\hline
\end{tabular}

${ }^{\mathrm{a}-\mathrm{b}}$ Means for the same trait between groups with different superscript are different $(\mathrm{p}<0.10)$.

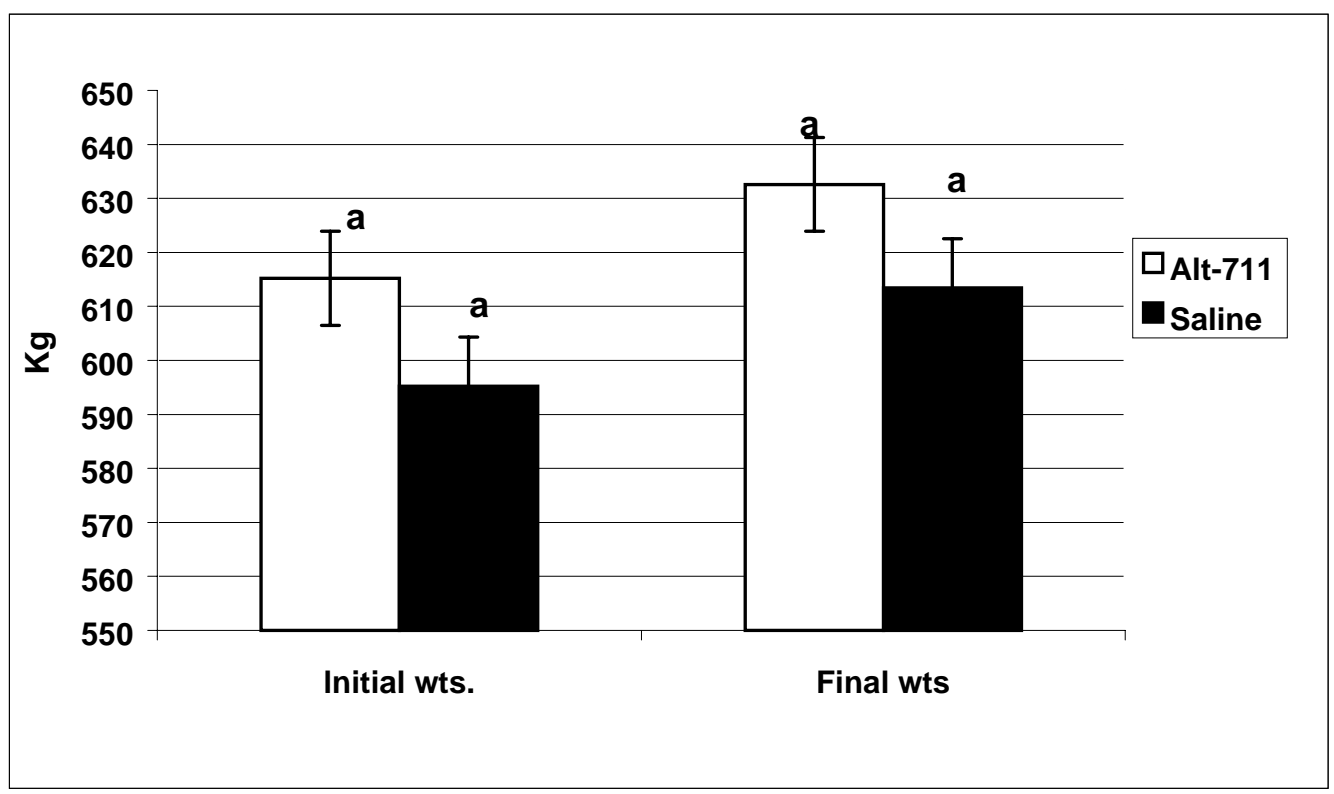

Figure 4-1. Initial and final body weights of each treatment group. Each bar represents the mean $(n=5) \pm$ SEM. ${ }^{a}$ Means with same superscript are not different $(p>0.05)$. Alt$711=$ Treated, Saline $=$ Control.

\subsection{Fat thickness}

Fat thickness for each teatment group is shown in Figure 4-2, with means of 0.86, 0.91 and $1.09 \mathrm{~cm}$ for control, ALT-711 treated, and A-maturity groups, 
respectively. A-maturity group had a higher fat thickness than control and ALT-711 treated groups, but the difference was not significant $(\mathrm{p}>0.05)$.

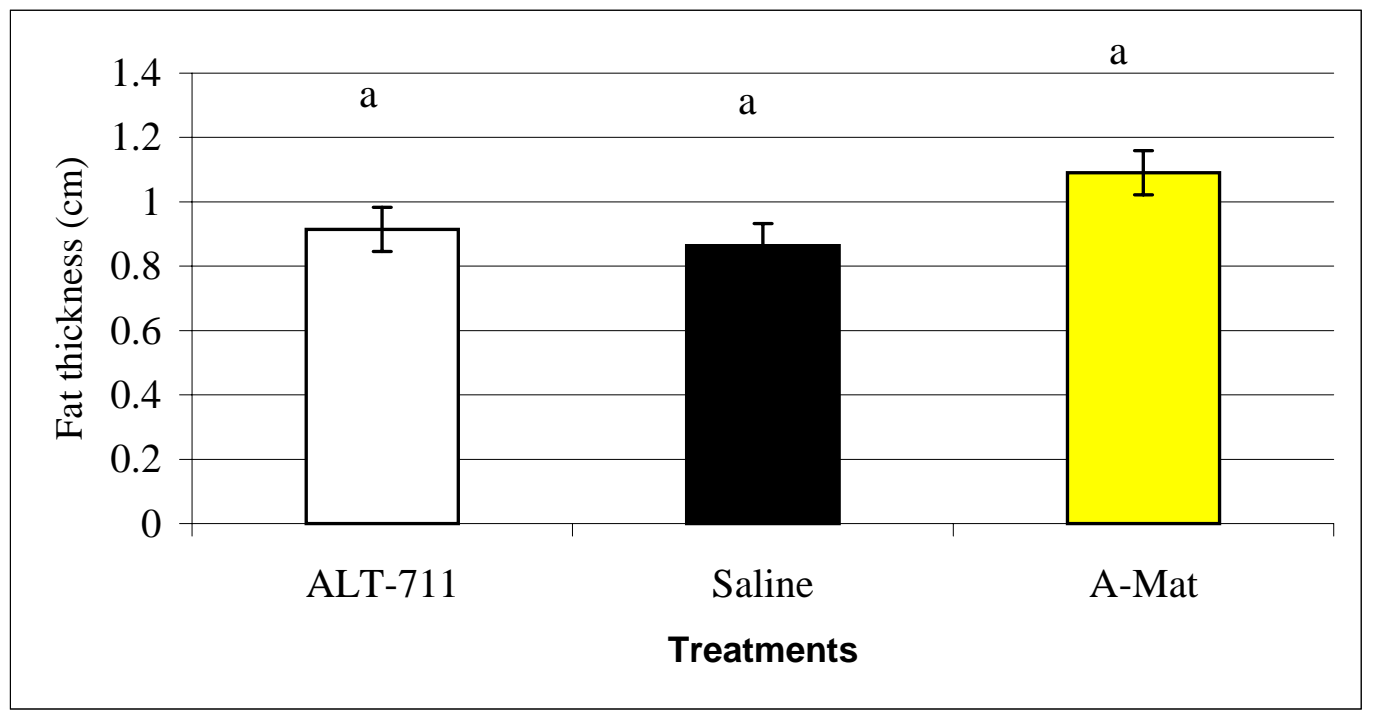

Figure 4-2. Fat thickness for each treatment group. Each bar represents the mean $(n=5) \pm$ SEM. ${ }^{a}$ Means with same superscript are not different $(\mathrm{p}>0.05)$. Alt-711=Treated, Saline $=$ Control, A-mat. $=$ A-maturity.

A strong relationship between fat thickness and the number of days on feed was found for control and ALT-711 treated group (Figure 4-3). The correlation coefficient for control was $\mathrm{R}^{2}=0.86$ and $\mathrm{R}^{2}=0.72$ for treated group, respectively. 


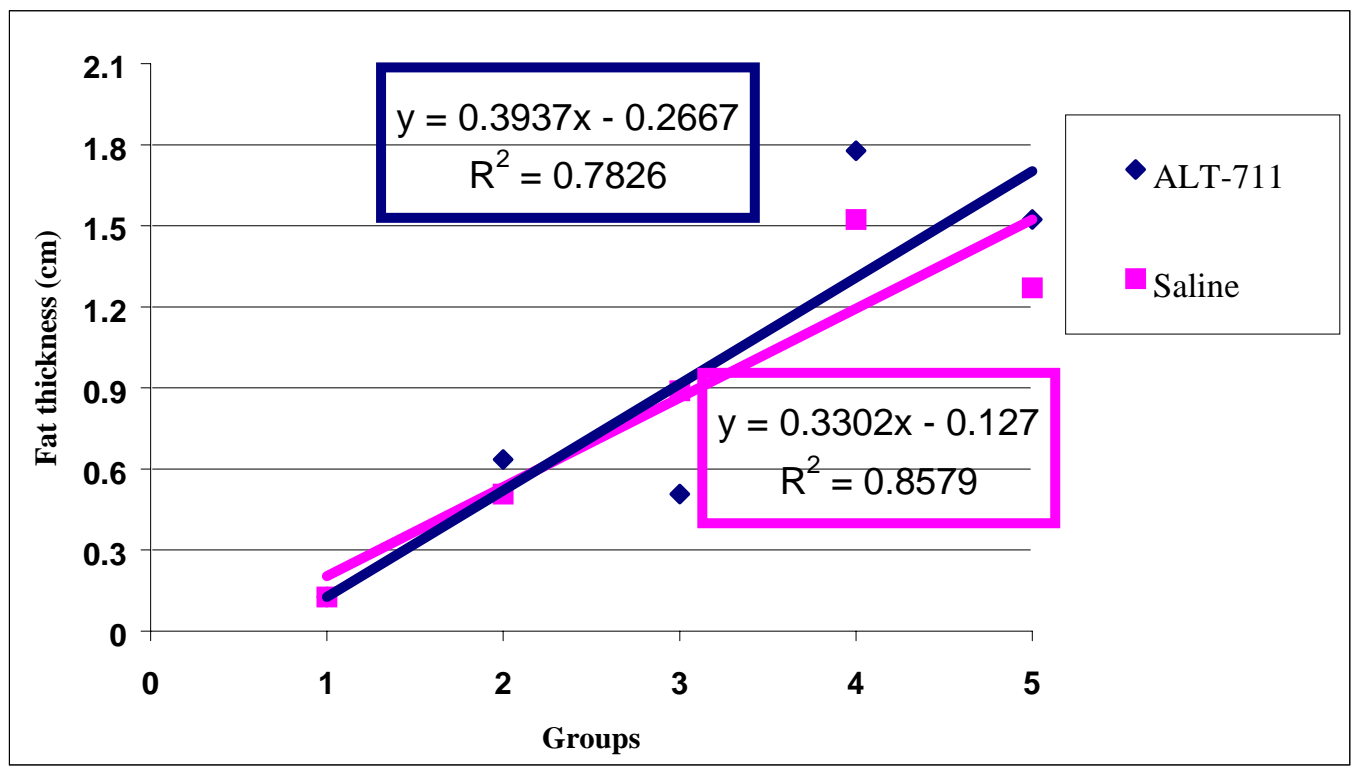

Figure 4-3. Relationship between fat thickness and the number of days on feed. Group $1=51$ days, group $2=66$ days, group $3=88$ days, group $4=91$ days, group 5=101 days. Alt$711=$ Treated, Saline $=$ Control.

\subsection{Color}

Surface color measurements $\mathbf{L}^{*} \mathbf{a}^{*}$ and $\mathbf{b}^{*}$ are shown in Figure 4-4 and Tables 4-4, 4-5, 4-6. A-maturity group (A-mat) had higher $\mathbf{L}^{*}$ values compared to control (C) and ALT-711 treated (T) groups (Figure 4-4) as follow longissimus thoracis (LT), $(\mathrm{p}<0.10)$; triceps brachii $(\mathrm{TB}),(\mathrm{p}<0.05)$; biceps femoris $(\mathrm{BF})(\mathrm{p}<0.05, \mathrm{p}<0.10)$, and $(\mathrm{p}<0.10)$ for semimembranosus $(\mathrm{SM})$. ALT-711 treated animals had a greater $\mathbf{L}^{*}$ values $(\mathrm{p}<0.10)$ compared to control animals for biceps femoris muscle. Muscles such as longissimus thoracis, semiembranosus, supraspinaturs, and biceps femoris of control animals were darker compared to Alt-711 treated animals. 


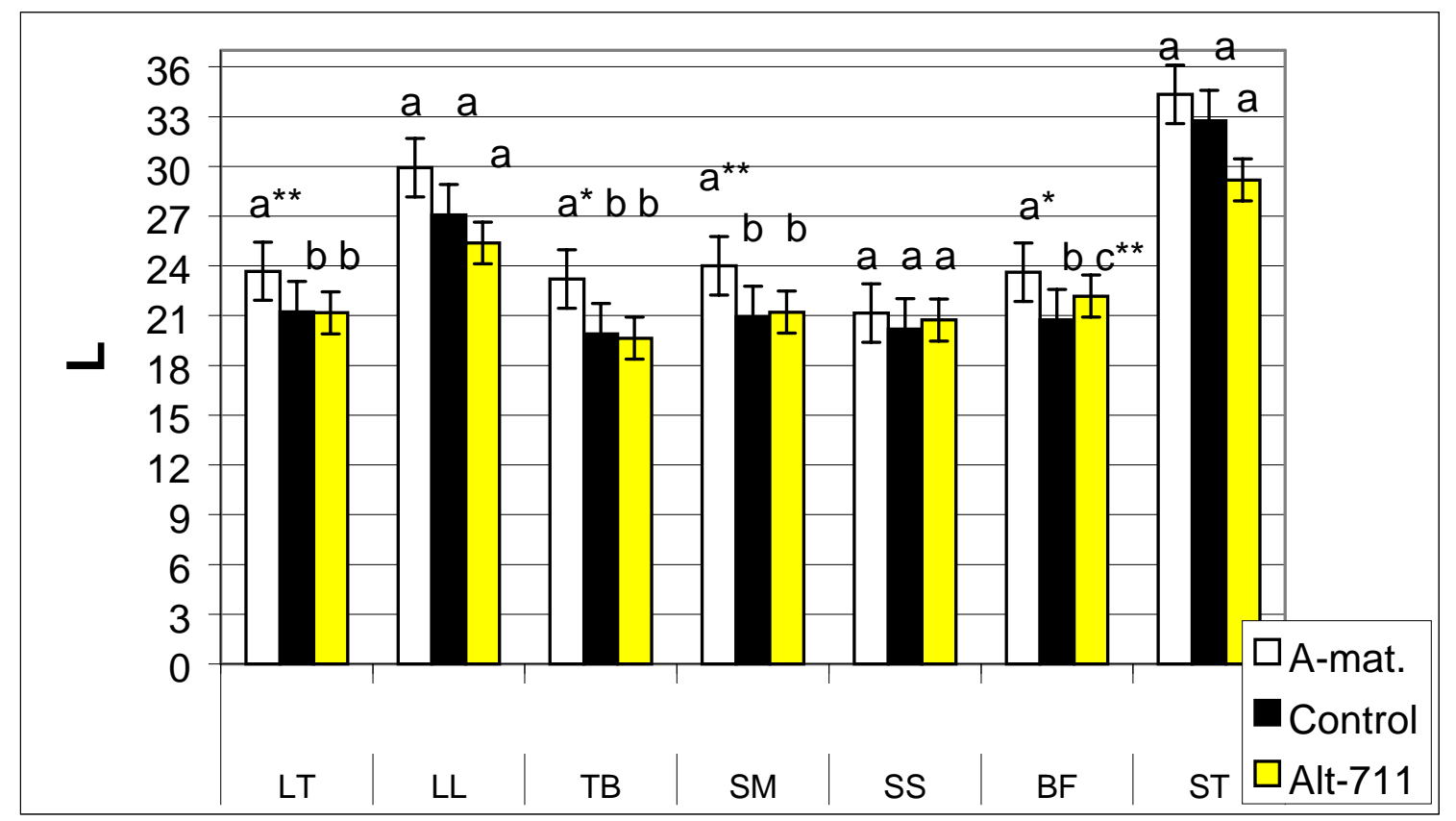

Figure 4-4. Relationship between Lightness $\left(\mathbf{L}^{*}\right)$ and muscle types. Each bar represents the mean $(n=5) \pm$ SEM. ${ }^{a-c}$ Means with different superscript are different $\left(p<0.05^{*}\right.$ and $\left.\mathrm{p}<0.10^{* *}\right) . \mathrm{LT}=$ Longissimus thoracis, $\mathrm{LL}=$ Longissimus lumborum, $\mathrm{TB}=$ Triceps brachii, $\mathrm{SS}=$ Supraspinatus, $\mathrm{ST}=$ Semitendinosus, $\mathrm{BF}=$ Biceps femoris, $\mathrm{SM}=$ Semimebranosus, $\mathrm{C}=$ Control, Alt-711=Treated, A-mat. =A-maturity.

Redness values $\mathbf{a}^{*}$ tended to be higher but not significant ( $\left.p>0.05\right)$ for the ALT711 treated group as follow $\mathrm{T}>\mathrm{A}-\mathrm{mat}>\mathrm{C}$ for longissimus thoracis, and $\mathrm{C}>\mathrm{A}-\mathrm{Mat}>\mathrm{T}$ for triceps brachii. Biceps femoris for A-maturity had higher $\mathbf{a}^{*}$ and $\mathbf{b}^{*}$ values compared to control and treated groups, however the means were not significant $(p>0.10)$. Muscle $\mathbf{b}^{*}$ values were higher $(\mathrm{p}<0.05)$ for biceps femoris for A-maturity animals compared to control and Alt-711 and not different $(\mathrm{p}>0.10)$ for the remaining mucles. For longissimus lumborum, supraspinatus, semitendinosus muscles surface color was measured but the samples were not allowed to bloom 30 minutes as was done for the other 4 muscles. 
Table 4-4. Mean Shear force (SF) values and physical characteristics for longissimus thoracis and longissimus lumborum muscles for the Control, Alt-711 treated, and Amaturity groups.

Longissimus thoracis

\begin{tabular}{|c|c|c|c|c|c|c|c|c|c|c|c|c|}
\hline \multirow[b]{2}{*}{ Trait } & \multicolumn{2}{|c|}{ Control } & \multicolumn{2}{|c|}{ Alt-711 } & \multicolumn{2}{|l|}{ A-Mat } & \multicolumn{2}{|c|}{ Control } & \multicolumn{2}{|l|}{ ALT-711 } & \multicolumn{2}{|c|}{ A-Mat } \\
\hline & Mean & S.E & Mean & S.E. & Mean & S.E. & Mean & S.E & Mean & S.E & Mean & S.E \\
\hline Color & & & & & & & & & & & & \\
\hline $\mathbf{a}^{*}$ & $7.9^{\mathrm{a}}$ & 0.53 & $8.94^{\mathrm{a}}$ & 0.8 & $8.22^{\mathrm{a}}$ & 0.44 & $10.3^{\mathrm{a}}$ & 0.43 & $9.04^{\mathrm{a}}$ & 0.81 & $6.52^{\mathrm{b} *}$ & 0.9 \\
\hline $\mathbf{b}^{*}$ & $9.5^{\mathrm{a}}$ & 0.44 & $8.82^{\mathrm{a}}$ & 0.5 & $8.88^{\mathrm{a}}$ & 0.2 & $9.1^{\mathrm{a}}$ & 0.66 & $8.7^{\mathrm{a}}$ & 0.88 & $9.68^{\mathrm{a}}$ & 0.9 \\
\hline Raw wt. $\quad$ (g) & 174 & 10.3 & 182 & 6.6 & 184 & 10.8 & 178 & 26.7 & 208 & 17.7 & 194 & 12 \\
\hline Initial temp. $\left({ }^{0} \mathrm{C}\right)$ & 5.32 & 0.47 & 5.8 & 0.4 & 5.6 & 0.4 & 5.8 & 0.37 & 5.4 & 0.24 & 5.4 & 0.2 \\
\hline Cooking time (min) & $34.3^{\mathrm{a}}$ & 2.57 & $41.6^{\mathrm{a}}$ & 3.6 & $37.2^{\mathrm{a}}$ & 4.8 & $42^{\mathrm{a}}$ & 4 & $41.2^{\mathrm{a}}$ & 2.59 & $36^{\mathrm{a}}$ & 2.2 \\
\hline Cooked wt. (g) & 109.2 & 4.96 & 118 & 2 & 130 & 3.16 & 116 & 14.7 & 134 & 12.9 & 126 & 5.1 \\
\hline Cooking loss $(\%)$ & $33^{\mathrm{a}}$ & 2.22 & $34.8^{\mathrm{a}}$ & 2.7 & $28.3^{\mathrm{a}}$ & 4.58 & $34.0^{\mathrm{a}}$ & 2.9 & $35.5^{\mathrm{a}}$ & 2.7 & $34.6^{\mathrm{a}}$ & 2.1 \\
\hline Shear force $(\mathrm{kg})$ & $5.02^{\mathrm{a}}$ & 0.3 & $5.0^{\mathrm{a}}$ & 0.21 & $4.08^{b * *}$ & 0.39 & $4.9^{\mathrm{a}}$ & 0.54 & $5.2^{\mathrm{a}}$ & 0.76 & $4.5^{\mathrm{a}}$ & 0.4 \\
\hline $\mathrm{pH}$ & $5.74^{\mathrm{a}}$ & 0.02 & $5.72^{\mathrm{a}}$ & 0.02 & $5.69^{\mathrm{a}}$ & 0.01 & $5.75^{\mathrm{a} *}$ & 0.04 & $5.67^{\mathrm{b} * *}$ & 0.04 & $5.61^{\mathrm{b}}$ & 0.02 \\
\hline
\end{tabular}

${ }^{a-b}$ Means within the same row and muscle with different superscript are different $\left(\mathrm{p}<0.05^{*} \mathrm{p}<0.10^{* *}\right) . \mathrm{C}=$ Control, Alt-711=Treated, A-mat. =A-maturity.

Table 4-5. Mean shear force (SF) values and physical characteristics for triceps brachi and supraspinatus muscles for the Control, Alt-711 treated, and A-maturity groups.

Triceps brachii

\begin{tabular}{|c|c|c|c|c|c|c|c|c|c|c|c|c|}
\hline \multirow[t]{2}{*}{ Trait } & \multicolumn{2}{|l|}{ Control } & \multicolumn{2}{|c|}{ ALT-711 } & \multicolumn{2}{|l|}{ A-Mat } & \multicolumn{2}{|c|}{ Control } & \multicolumn{2}{|l|}{ ALT-711 } & \multicolumn{2}{|l|}{ A-Mat } \\
\hline & Mean & S.E & Mean & S.E & Mean & S.E. & Mean & S.E & Mean & S.E & Mean & S.E \\
\hline Color & & & & & & & & & & & & \\
\hline$a^{*}$ & $10.48^{\mathrm{a}}$ & 1.63 & $9.3^{\mathrm{a}}$ & 0.97 & $10.12^{\mathrm{a}}$ & 0.98 & $10.4^{\mathrm{a}}$ & 0.97 & $7.9^{b * *}$ & 0.71 & $9.9^{\mathrm{a}, \mathrm{b}}$ & 0.45 \\
\hline b* & $9.18^{\mathrm{a}}$ & 0.26 & $9.26^{\mathrm{a}}$ & 0.9 & $10.7^{\mathrm{b*}}$ & 0.52 & $7.7^{\mathrm{a}}$ & 0.39 & $7.4^{\mathrm{a}}$ & 0.19 & $8.6^{\mathrm{a}}$ & 0.28 \\
\hline Raw wt. & 512 & 30.2 & 540 & 41.5 & 420 & 35.4 & 120 & 8.94 & 138 & 9.69 & 132 & 4.89 \\
\hline Initial temp. (C) & 5.6 & 0.24 & 5.8 & 0.2 & 5.6 & 0.67 & 5.8 & 0.2 & 5.4 & 0.4 & 5.6 & 0.4 \\
\hline Cook time $(\min )$ & $49.6^{\mathrm{a}}$ & 3.24 & $53.2^{\mathrm{a}}$ & 2.2 & $48.6^{\mathrm{a}}$ & 1.74 & $45^{\mathrm{a}}$ & 1.1 & $47^{\mathrm{a}}$ & 3.11 & $43.8^{\mathrm{a}}$ & 3.21 \\
\hline Cooked wt. (g) & 322 & 27.6 & 322 & 33.9 & 278 & 24.8 & 74 & 6.78 & 82 & 4.89 & 78 & 3.74 \\
\hline Cooking loss (\%) & $37.4^{\mathrm{a}}$ & 2.1 & $40.8^{\mathrm{a}}$ & 2.2 & $54.3^{\mathrm{b} *}$ & 1.59 & $38.3^{\mathrm{a}}$ & 3.25 & $40.3^{\mathrm{a}}$ & 2.19 & $41.0^{\mathrm{a}}$ & 5.34 \\
\hline Shear force $(\mathrm{kg})$ & $4.77^{\mathrm{a} * *}$ & 0.28 & $5.46^{c * *}$ & 0.36 & $3.67^{b *}$ & 0.1 & $6.58^{\mathrm{a}}$ & 0.33 & $6.79^{\mathrm{a}}$ & 0.55 & $5.33^{\mathrm{b} *}$ & 0.2 \\
\hline $\mathrm{pH}$ & $5.77^{\mathrm{ab}}$ & 0.02 & $5.79^{\mathrm{b} * *}$ & 0.03 & $5.73^{\mathrm{a}}$ & 0.02 & $5.95^{\mathrm{a}}$ & 0.02 & $5.95^{\mathrm{a}}$ & 0.02 & $5.93^{\mathrm{a}}$ & 0.01 \\
\hline
\end{tabular}

${ }^{\mathrm{a}-\mathrm{c}}$ Means within the same row and muscle with different superscript are different $\left(\mathrm{p}<0.05^{*}\right.$ and $\left.\mathrm{p}<0.10^{* * *}\right) . \mathrm{C}=$ Control, Alt-711=Treated, A-mat. =A-maturity. 
Table 4-6. Mean Shear force (SF) values and physical characteristics for Biceps femoris and Semitendinosus muscles for the Control, Alt-711 treated, and Amaturity groups.

Biceps femoris

\begin{tabular}{|c|c|c|c|c|c|c|c|c|c|c|c|c|}
\hline \multirow{2}{*}{ Trait } & \multicolumn{2}{|c|}{ Control } & \multicolumn{2}{|c|}{ ALT-711 } & \multicolumn{2}{|c|}{ A-Mat } & \multicolumn{2}{|c|}{ Control } & \multicolumn{2}{|c|}{ ALT-711 } & \multicolumn{2}{|l|}{ A-Mat } \\
\hline & Mean & S.E & Mean & S.E. & Mean & S.E. & Mean & S.E & Mean & S.E & Mean & S.E \\
\hline Color & & & & & & & & & & & & \\
\hline $\mathbf{a}^{*}$ & $9.94^{\mathrm{a}}$ & 0.52 & $9.5^{\mathrm{a}}$ & 1.1 & $9.99^{\mathrm{a}}$ & 0.86 & $6.6^{\mathrm{a}}$ & 0.72 & $9.5^{\mathrm{b} * *}$ & 1.09 & $6.9^{\mathrm{a}}$ & 0.94 \\
\hline$b^{*}$ & $8.6^{\mathrm{a}}$ & 0.36 & $8.58^{\mathrm{a}}$ & 0.3 & $9.04^{\mathrm{a}}$ & 0.41 & $13.6^{\mathrm{a}}$ & 0.98 & $12.6^{\mathrm{a}}$ & 1.14 & $13.1^{\mathrm{a}}$ & 0.66 \\
\hline Raw wt. & 352 & 40.4 & 398 & 35 & 376 & 28.4 & 180 & 10 & 194 & 16.3 & 184 & 11.2 \\
\hline Initial temp. $\left({ }^{0} \mathrm{C}\right)$ & 5.4 & 0.5 & 4.8 & 0.2 & 5.2 & 0.2 & 5.4 & 0.4 & 4.8 & 0.49 & 5.6 & 0.4 \\
\hline Cook time (min) & $43^{\mathrm{a}}$ & 3.61 & $42^{\mathrm{a}}$ & 2.9 & $39^{\mathrm{a}}$ & 2.58 & $53.4^{\mathrm{a}}$ & 3.48 & $59.6^{\mathrm{a}}$ & 2.64 & $48.4^{\mathrm{b} * *}$ & 2.2 \\
\hline Cooked wt. $\quad$ (g) & 238 & 24.4 & 274 & 20.0 & 264 & 20.6 & 106 & 6.78 & 110 & 11.4 & 118 & 7.34 \\
\hline Cooking loss (\%) & $32.4^{\mathrm{a}}$ & 0.97 & $30.8^{\mathrm{a}}$ & 1.2 & $42.5^{\mathrm{b} *}$ & 1.02 & $41.2^{\mathrm{a}}$ & 1.05 & $43.6^{\mathrm{a}}$ & 1.17 & $35.8^{\mathrm{b} *}$ & 1.97 \\
\hline Shear force $(\mathrm{kg})$ & $12.25^{\mathrm{a}}$ & 1.49 & $11.09^{\mathrm{a}}$ & 0.5 & $8.06^{b *}$ & 0.65 & $5.95^{\mathrm{a}}$ & 0.5 & $6.66^{\mathrm{a}}$ & 0.46 & $4.67^{b *}$ & 0.23 \\
\hline $\mathrm{pH}$ & $5.65^{\mathrm{a}}$ & 0.02 & $5.63^{\mathrm{a}}$ & 0.01 & $5.62^{\mathrm{a}}$ & 0.01 & $5.65^{\mathrm{a}}$ & 5.64 & $5.64^{\mathrm{a}}$ & 0.02 & $5.65^{\mathrm{a}}$ & 0.01 \\
\hline
\end{tabular}

${ }^{\mathrm{a}-\mathrm{b}}$ Means within the same row and muscle with different superscript are different $\left(\mathrm{p}<0.05^{*}\right.$ and $\left.\mathrm{p}<0.10^{* *}\right) . \mathrm{C}=\mathrm{Control}$, Alt-711=Treated, A-mat. $=\mathrm{A}-\mathrm{maturity}$.

Table 4-7. Mean shear force (SF) values and physical characteristics for Semimembranossus muscle for the Control, Alt-711 treated, and A-maturity groups.

\begin{tabular}{|c|c|c|c|c|c|c|}
\hline \multirow[b]{2}{*}{ Trait } & \multirow{2}{*}{\multicolumn{2}{|c|}{ Control }} & \multirow{2}{*}{\multicolumn{2}{|c|}{ ALT-711 }} & \multirow{2}{*}{\multicolumn{2}{|c|}{ A-Mat }} \\
\hline & & & & & & \\
\hline Color & & S.E & & S.L & & \\
\hline$a^{*}$ & $9.08^{\mathrm{a}}$ & 1.36 & $8.5^{\mathrm{a}}$ & 0.62 & $8.7^{\mathrm{a}}$ & 1.17 \\
\hline b* & $10.94^{\mathrm{a}}$ & 0.32 & $10.1^{\mathrm{a}}$ & 0.31 & $10.96^{\mathrm{a}}$ & 0.55 \\
\hline Raw wt. $\quad$ (g) & 380 & 29.5 & 412 & 16.0 & 384 & 10.3 \\
\hline Initial temp. $\quad\left({ }^{0} \mathrm{C}\right)$ & 5.2 & 0.2 & 6.0 & 0.84 & 5.0 & 0.54 \\
\hline Cooking time (min) & $49.6^{\mathrm{a}}$ & 3.74 & $49.4^{\mathrm{a}}$ & 6.0 & $44.2^{\mathrm{a}}$ & 1.77 \\
\hline Cooked wt. $\quad(\mathrm{g})$ & 228 & 22.2 & 246 & 10.77 & 238 & 8.0 \\
\hline Cooking loss $(\%)$ & $40.3^{\mathrm{a}}$ & 1.84 & $40.2^{\mathrm{a}}$ & 1.72 & $38.0^{\mathrm{a}}$ & 0.8 \\
\hline Shear force $\quad(\mathrm{kg})$ & $7.19^{\mathrm{a}}$ & 0.82 & $7.1^{\mathrm{a}}$ & 0.59 & $6.03^{\mathrm{a}}$ & 0.11 \\
\hline $\mathrm{pH}$ & $5.62^{\mathrm{a}}$ & 0.02 & $5.58^{\mathrm{a}}$ & 0.02 & $5.59^{\mathrm{a}}$ & 0.01 \\
\hline
\end{tabular}

${ }^{a-b}$ Means within the same row and muscle with different superscript are different $\left(\mathrm{p}<0.05^{*}\right.$ and $\left.\mathrm{p}<0.10^{* *}\right) . \mathrm{C}=$ Control, Alt-711=Treated, A-mat. =A-maturity. 


\subsection{Cooking time}

Cooking time (Tables 4-4, 4-5, 4 -6, 4-7) was lower for the A-maturity group compared to control and ALT-711 treated groups: the order was as follow triceps brachi, A-mat $<\mathrm{C}<$ Alt-711; supraspinatus, A-mat $<\mathrm{C}<$ Alt-711; longissimus lumborum, A-mat $<$ Alt-711<C; biceps femoris A-mat $<$ Alt-711<C; semimebranosus A-mat. $<$ Alt-711 $<\mathrm{C}$; and significantly lower $(\mathrm{p}<0.10)$ for semitendinosus A-mat. $<\mathrm{C}<$ Alt-711. However, longissimus thoracis had longer coking time for A-maturity group compared to control.

\subsection{Cooking loss}

Cooking loss (Tables 4-4, 4-5, 4-6, 4-7) was lower for the A-maturity group, and not significant $(\mathrm{p}>0.10)$, the order from the smallest to highest cooking loss for the following muscles: longissimus thoracis, A-mat. $<\mathrm{C}<$ Alt-711; semimembranousus, Amat. $<\mathrm{C}<$ Alt-711; and significant $(\mathrm{p}<0.05)$ for semitendinossus, A-mat. $<\mathrm{C}<$ Alt-711. The control group had a lower cooking loss, not significant ( $p>0.10)$ for following muscles longissimus lumborum, $\mathrm{C}<\mathrm{A}$-mat. $<$ Alt-711; supraspinatus, $\mathrm{C}<$ Alt-711 $<\mathrm{A}$-mat., and significantly lower $(\mathrm{p}<0.05)$ for triceps brachii of control animals compared to Alt-711 and A-maturity animals. Cooking loss for biceps femoris for A-maturity animals was significantly higher $(\mathrm{p}<0.05)$ compared to control and Alt-711 treated animals. However, semitendinossus, semimembranosus muscle had a shorter cooking time and a lower cooking loss for the A-matruity group, and longissimus thoracis had lowest cooking loss despite its longer cooking time compared to the control group, longissimus lumborum had lowest cooking time and a slightly higher cooking loss compared to the control group. 


\subsection{Shear force}

Mean Warner-Bratzler shear force were lower for A-maturity group compared to Control and Alt-711 treated groups, respectively (Tables 4-4, 4-5, 4-6, 4-7). A-maturity animals consistently had significantly lower shear force values $(\mathrm{p}<0.10)$ as follow AMat $<\mathrm{C}<\mathrm{T}$, for longissimus thoracis, and $(\mathrm{p}<0.05)$ biceps femoris, semitendinosus, supraspinatus, semimembranosus, and triceps brachii, and lower but not significant ( $p>0.10)$ for longissimus lumborum and semimembranosus. Overall, muscles from the A-maturity group were more tender (lower shear force) $(\mathrm{p}<0.05)$ than muscles from Ematurity groups, with the exception of the longissimus lumborum and semimembranosus muscles for the linear contrast old vs A-mat (F-test; Table 4-9). Triceps brachii had lowest shear force value compared to the other muscles, the order from the lowest to highest shear force being as follow $\mathrm{TB}<\mathrm{LT}<\mathrm{LL}<\mathrm{ST}<\mathrm{SS}<\mathrm{SM}<\mathrm{BF}$ for A-maturity and control groups (Figure 4- 5). 


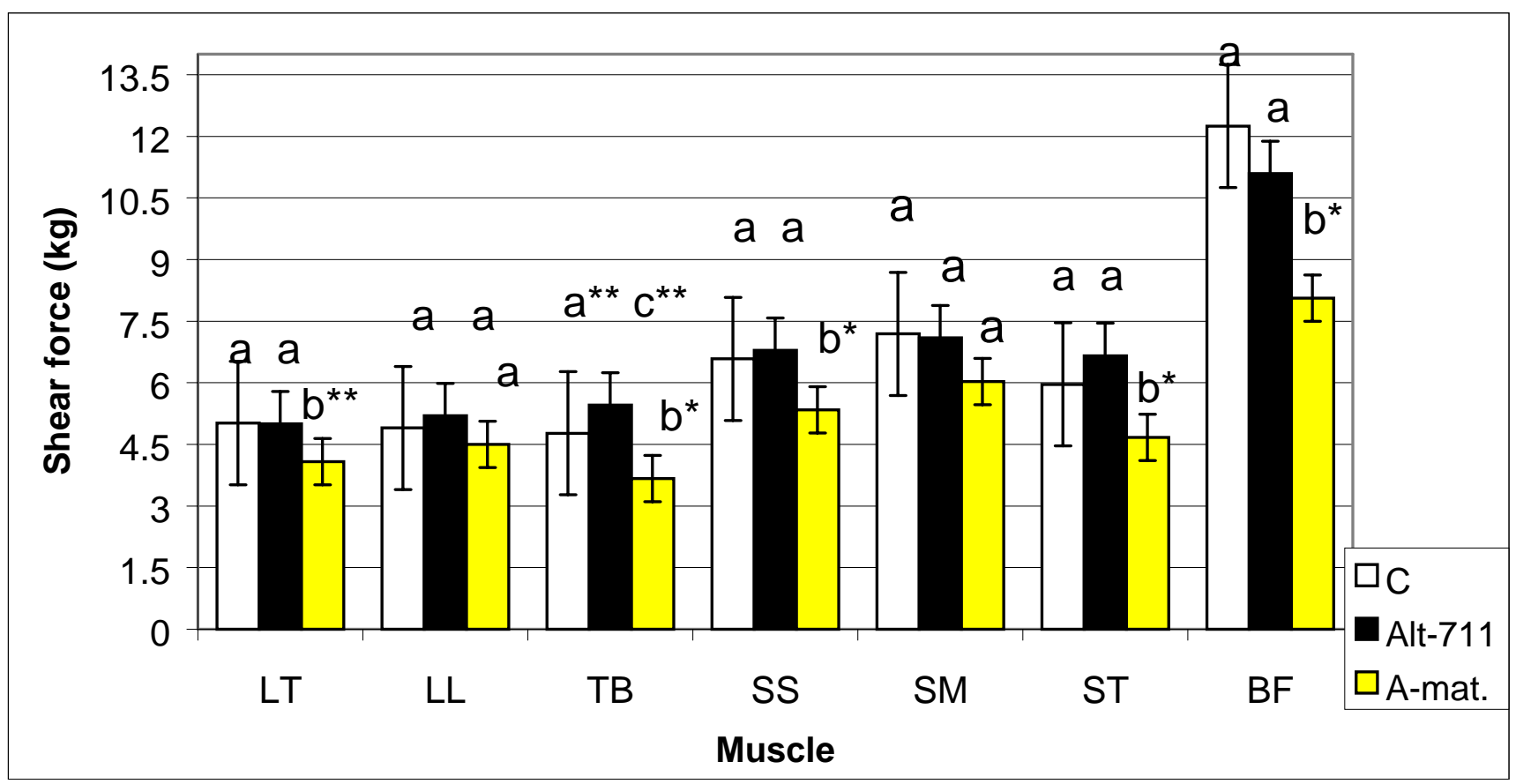

Figure 4-5. Age and Alt-711 effect on muscle tenderness (shear force). Each bar $(n=5)$ represents the mean \pm SEM. ${ }^{a-c}$ Means with different superscript are different $\left(p<0.05^{*}\right.$ and $\mathrm{p}<0.10^{* *}$ ). $\mathrm{LT}=$ Longissimus thoracis, $\mathrm{LL}=$ Longissimus lumborum, $\mathrm{TB}=$ Triceps brachii, $\mathrm{SS}=$ Supraspinatus, $\mathrm{ST}=$ Semitendinosus, $\mathrm{BF}=\mathrm{Biceps}$ femoris, $\mathrm{SM}=$ Semimebranosus, $\mathrm{C}=$ Control, Alt-711=Treated, A-mat. =A-maturity.

Muscles tenderness decreased with increasing chronological age (Figure 4-6). A strong relationship was found between age and tenderness for following muscles: biceps femoris $\left(\mathrm{R}^{2}=0.94\right)$, semimembranosus $\left(\mathrm{R}^{2}=0.81\right)$, longissimus lumborum $\left(\mathrm{R}^{2}=0.77\right)$, supraspinatus $\left(\mathrm{R}^{2}=0.63\right)$, and a weak relationship for longissimus thoracis $\left(\mathrm{R}^{2}=0.32\right)$, triceps brachii $\left(\mathrm{R}^{2}=0.37\right)$, semitendinosus $\left(\mathrm{R}^{2}=0.40\right)$. 


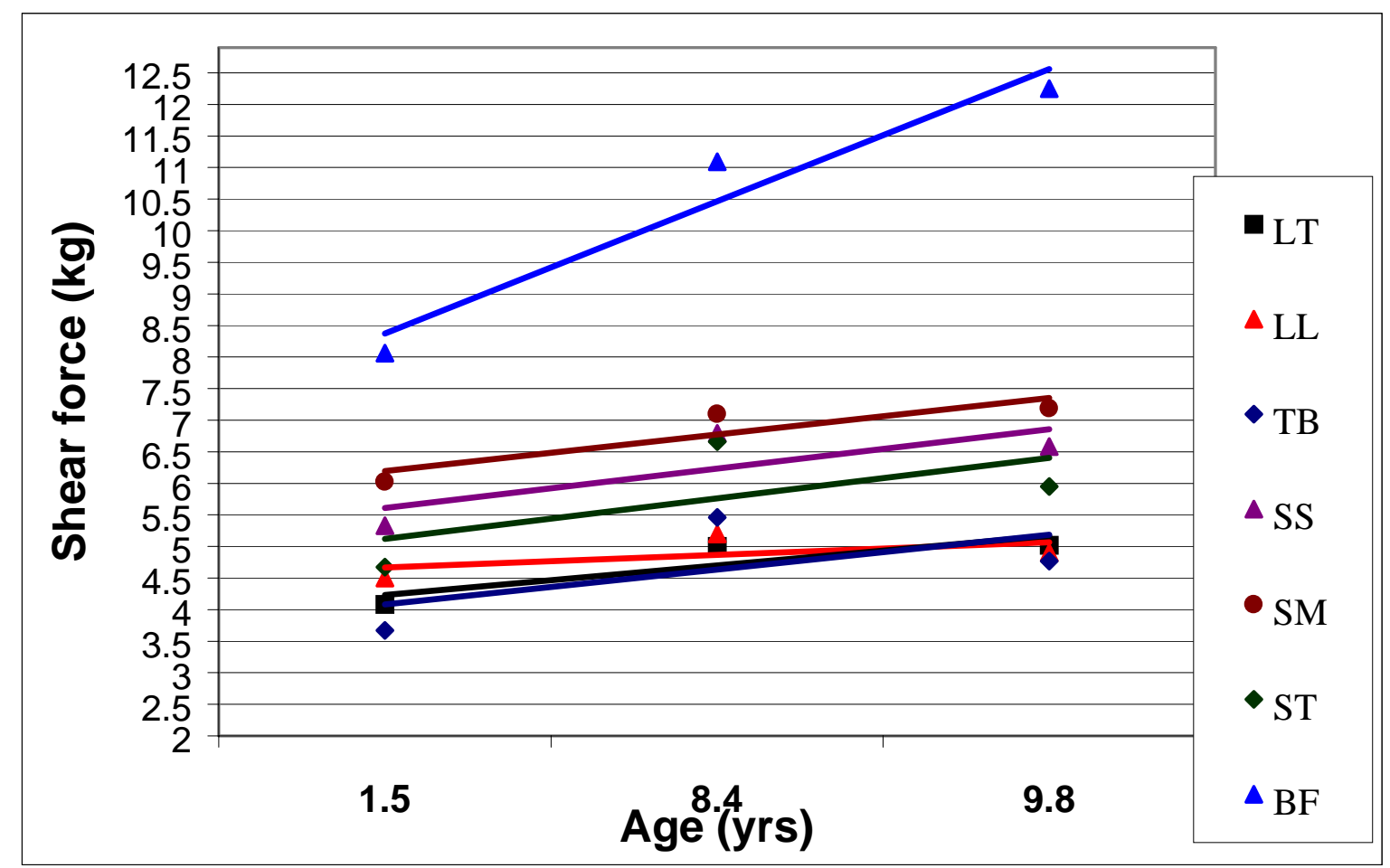

Figure 4-6. Changes in muscle tenderness as a function of age. Each sign represents the mean $(n=5)$ of A-maturity $=1.5$ years, Alt $-711=8.4$ years, Control $=9.8$ years. $\mathrm{LT}=$ Longissimus thoracis, $\mathrm{LL}=$ Longissimus lumborum, $\mathrm{TB}=$ Triceps brachi, $\mathrm{SS}=$ Supraspinatus, $\mathrm{ST}=$ Semitendinosus, $\mathrm{BF}=$ Biceps femoris, $\mathrm{SM}=$ Semimebranosus

\section{$4.7 \mathrm{pH}$}

Muscle pH means are summarized in Tables 4-4, 4-5, 4 -6, 4-7. Overall, Amaturity had a lower $\mathrm{pH}$ compared to control and treated groups as follow (A-mat $<$ Alt$711<\mathrm{C}$ ) for longissimus thoracis, semimbranosus, supraspinatus, and biceps femoris. Muscles of Alt-711 treated animals had a lower $\mathrm{pH}$ as follows (Alt-711<A-mat $<\mathrm{C}$ ) for semimembranosus, and (Alt-711<C<A-Mat.) for semitendinosus. Longissimus lumborrum for A-maturity had a significantly lower $\mathrm{pH}(\mathrm{p}<0.05)$ compared to control, and the treated animals had a significantly lower $\mathrm{pH}(\mathrm{p}<0.10)$ compared to control. 
Triceps brachii for A-maturity group had a significantly lower $\mathrm{pH}(\mathrm{p}<0.10)$ than Alt-711 treated animals (Figure 4-7). Semimembranosus muscle had the lowest $\mathrm{pH}$, reflecting its high proportion of white fibres and its anaerobic metabolism. Supraspinatus had the highest $\mathrm{pH}$ among muscles, being a muscle with oxidative metabolism.

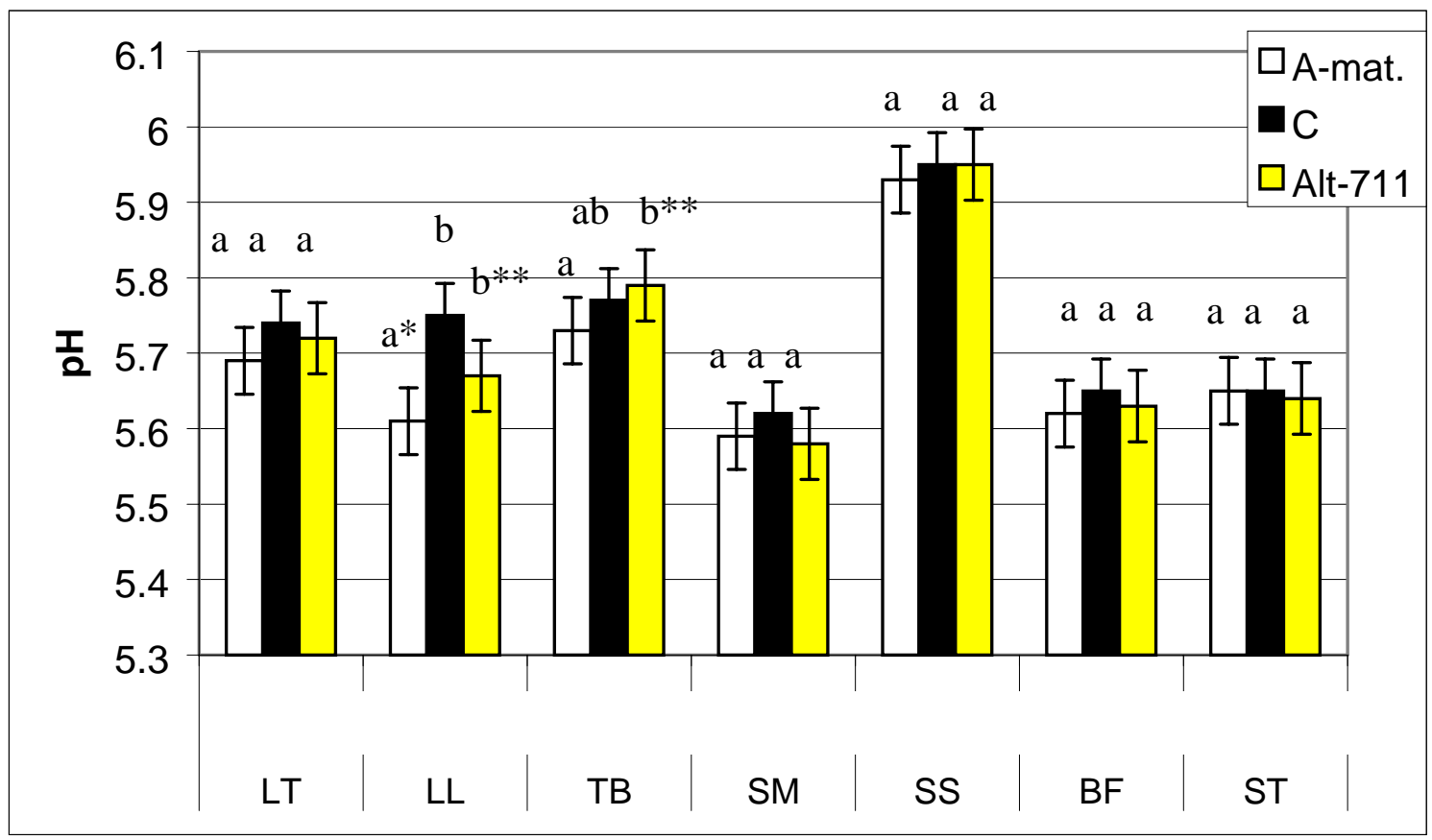

Figure 4-7. Relatonship between muscle and $\mathrm{pH}$. Each bar represents the mean $(\mathrm{n}=5) \pm$ SEM. ${ }^{\mathrm{a}-\mathrm{c}}$ Means with different superscript are different $\left(\mathrm{p}<0.05^{*}\right.$ and $\left.\mathrm{p}<0.10^{* *}\right)$. $\mathrm{LT}=$ Longissimus thoracis, $\mathrm{LL}=$ Longissimus lumborum, $\mathrm{TB}=$ Triceps brachi, $\mathrm{SS}=$ Supraspinatus, $\mathrm{ST}=$ Semitendinosus, $\mathrm{BF}=$ Biceps femoris, $\mathrm{SM}=$ Semimebranosus, $\mathrm{C}=$ Control, Alt-711=Treated, A-mat. =A-maturity.

Also, muscle of hind limb (semimebranosus, semitendinosus and biceps femoris) had a lower $\mathrm{pH}$ compared to the muscle of forehind (triceps brachii and supraspinatus). 


\subsection{Soluble, insoluble, and total collagen}

\subsubsection{Total collagen}

Total collagen content was higher for the E-maturity compared to A-maturity however, not significantly different (F-test; $\mathrm{p}>0.10$; Table 4-8). Longissimus lumborum, triceps brachii, and semimebranosus for A-maturity animals tended to have slightly higher total collagen content compared to control and Alt-711 treated animals (Table 48). Even though the total contents did not differ statistically, their tenderness was distinctly different. The amount of total collagen for the Alt-711 treated group was significantly higher $(\mathrm{p}<0.10)$ for triceps brachii compared to the control group (Alt-711 vs control). The total collagen content of the muscles in order from the most to the least total collagen was $\mathrm{SS}>\mathrm{ST}>\mathrm{BF}>\mathrm{TB}>\mathrm{SM}>\mathrm{LL}>\mathrm{LT}$, whereas the order for the quantity of soluble collagen from the most to the least was $\mathrm{ST}>\mathrm{TB}>\mathrm{BF}>\mathrm{SS}>\mathrm{LL}>\mathrm{LT}>\mathrm{SM}$ for Amaturity. Longissimus lumborum for A-maturity group had a higher amount of total collagen compared to control and Alt-711 treated group (3.77 mg vs $3.72 \mathrm{mg}$ vs 3.73 $\mathrm{mg}$ ). Shear force negative correlated with longissimus thoracis total collagen content $\left(\mathrm{R}^{2}=-0.18\right)$ for A-maturity and for ALT-711 treated animals $\left(\mathrm{R}^{2}=-0.79\right)$, and positive for control $\left(\mathrm{R}^{2}=0.39\right)$.

\subsubsection{Insoluble collagen}

Overall, the amount of insoluble collagen was lower for the following muscles longissimus lumborum, triceps brachii, semimebranosus, semitendinosus, and significantly lower $(\mathrm{p}<0.05)$ for the longissimus thoracis and biceps femoris of the Amaturity animals as compared to control animals. Supraspinatus of A-maturity animals had a significantly lower amount of insoluble collagen $(\mathrm{p}<0.10)$ when compared to 
control and not significant $(\mathrm{p}>0.10)$ when compared to the Alt-711treated group. Alt711 treated group had a significantly higher $(\mathrm{p}<0.05)$ insoluble collagen content for triceps brachii compared to control and A-maturity, however was not significantly different $(\mathrm{p}>0.10)$ for the longissimus thoracis, supraspinatus, and biceps femoris when compared to A-maturity, respectively. Supraspinatus seemed to have the highest amount of insoluble collagen and longissimus thoracis had the lowest amount of insoluble collagen for all treatments (Table 4-6). Shear force positively correlated with insoluble collagen of longissimus thoracis for control $\mathrm{R}^{2}=0.42, \mathrm{R}^{2}=-0.32$ for Alt-711, and negatively $\left(\mathrm{R}^{2}=-0.01\right)$ for A-maturity animals.

\subsubsection{Soluble collagen}

The amount of soluble collagen for A-maturity compared to control and Alt-711 treated animals was significantly higher $(\mathrm{p}<0.05$ and $\mathrm{p}<0.10)$ for all muscles, with the exception of the supraspinatus (Table 4-8). The Alt-711 treated animals had a higher content of soluble collagen but not significantly different $(p>0.10)$ compared to the control animals. It was also found that the amount of soluble collagen was highly negative correlated with back fat thickness $\left(\mathrm{R}^{2}=-0.95\right)$ and $\left(\mathrm{R}^{2}=-0.43\right)$ for the A-maturity and control animals respectively, whereas there was a strong positive relationship $\left(\mathrm{R}^{2}=0.75\right)$ for the Alt-711 treated animals. Also, soluble collagen negatively correlated with longissimus thoracis shear force as follow: A-maturity, $\mathrm{R}^{2}=-0.23$; control, $\mathrm{R}^{2}=0.13$; and Alt-711, $\mathrm{R}^{2}=-0.27$. 
Table 4-8. Effect of age and Alt-711 treatment on collagen characteristics.

\begin{tabular}{|c|c|c|c|c|c|c|}
\hline & Treatment & & $\begin{array}{l}\text { Soluble } \\
\text { collagen }(\mathrm{mg} / \mathrm{g})\end{array}$ & $\begin{array}{l}\text { Insoluble } \\
\text { collagen }(\mathrm{mg} / \mathrm{g})\end{array}$ & $\begin{array}{l}\text { Total } \\
\text { collagen }(\mathrm{mg} / \mathrm{g})\end{array}$ & $\begin{array}{l}\text { Soluble } \\
\text { collagen (\%) }\end{array}$ \\
\hline \multirow{6}{*}{ Longissimus lumborum } & \multirow{2}{*}{ Control } & Mean & $0.47^{\mathrm{a}}$ & $3.25^{\mathrm{a}}$ & $3.72^{\mathrm{a}}$ & $12.62^{\mathrm{a}}$ \\
\hline & & S.E. & 0.05 & 0.21 & 0.25 & 0.72 \\
\hline & \multirow[t]{2}{*}{ ALT-711 } & Mean & $0.69^{\mathrm{ab}}$ & $3.04^{\mathrm{a}}$ & $3.73^{\mathrm{a}}$ & $18.98^{\mathrm{ab}}$ \\
\hline & & S.E. & 0.16 & 0.27 & 0.14 & 5.04 \\
\hline & \multirow[t]{2}{*}{ A-Mat } & Mean & $0.98^{\mathrm{b}^{* * *}}$ & $2.79^{\mathrm{a}}$ & $3.77^{\mathrm{a}}$ & $24.91^{b * *}$ \\
\hline & & S.E. & 0.23 & 0.09 & 0.19 & 5.26 \\
\hline \multirow[t]{6}{*}{ Longissimus thoracis } & \multirow[t]{2}{*}{ Control } & Mean & $0.49^{\mathrm{a}}$ & $2.43^{\mathrm{a}}$ & $2.92^{\mathrm{a}}$ & $17.34^{\mathrm{a}}$ \\
\hline & & S.E. & 0.02 & 0.30 & 0.21 & 1.27 \\
\hline & \multirow[t]{2}{*}{ ALT-711 } & Mean & $0.62^{\mathrm{a}}$ & $2.01^{\mathrm{ab}}$ & $2.63^{\mathrm{a}}$ & $23.62^{\mathrm{a}}$ \\
\hline & & S.E. & 0.08 & 0.11 & 0.1 & 3.04 \\
\hline & \multirow[t]{2}{*}{ A-Mat } & Mean & $0.94^{b^{*}}$ & $1.79^{\mathrm{b}^{*}}$ & $2.73^{\mathrm{a}}$ & $34.07^{\mathrm{b}^{*}}$ \\
\hline & & S.E. & 0.11 & 0.07 & 0.15 & 3.03 \\
\hline \multirow{6}{*}{ Triceps brachii } & \multirow[t]{2}{*}{ Control } & Mean & $0.57^{\mathrm{a}}$ & $3.81^{\mathrm{a}}$ & $4.38^{\mathrm{a}^{* * *}}$ & $12.88^{\mathrm{a}}$ \\
\hline & & S.E. & 0.08 & 0.18 & 0.24 & 1.20 \\
\hline & \multirow[t]{2}{*}{ ALT-711 } & Mean & $0.81^{\mathrm{a}}$ & $4.92^{\mathrm{b}^{*}}$ & $5.74^{\mathrm{b}}$ & $14.19^{\mathrm{a}}$ \\
\hline & & S.E. & 0.05 & 0.3 & 0.33 & 0.85 \\
\hline & \multirow[t]{2}{*}{ A-Mat } & Mean & $1.87^{\mathrm{b}^{*}}$ & $3.54^{\mathrm{a}}$ & $5.41^{\mathrm{ab}}$ & $33.06^{\mathrm{b}^{*}}$ \\
\hline & & S.E. & 0.44 & 0.41 & 0.76 & 3.78 \\
\hline \multirow{5}{*}{ Supraspinatus } & \multirow{2}{*}{ Control } & Mean & $1.22^{\mathrm{a}}$ & $6.45^{\mathrm{a}}$ & $7.67^{\mathrm{a}}$ & $15.58^{\mathrm{a}}$ \\
\hline & & S.E. & 0.23 & 0.30 & 0.42 & 2.43 \\
\hline & \multirow[t]{2}{*}{ ALT-711 } & Mean & $1.44^{\mathrm{a}}$ & $6.20^{\mathrm{ab}}$ & $7.64^{\mathrm{a}}$ & $18.78^{\mathrm{ab}}$ \\
\hline & & S.E. & 0.13 & 0.12 & 0.11 & 1.52 \\
\hline & A-Mat & Mean & $1.43^{\mathrm{a}}$ & $5.53^{\mathrm{b}^{* *}}$ & $6.96^{\mathrm{a}}$ & $20.32^{\mathrm{b}^{* *}}$ \\
\hline \multirow{7}{*}{ Biceps femoris } & \multirow{3}{*}{ Control } & S.E. & 0.19 & 0.43 & 0.58 & 1.48 \\
\hline & & Mean & $0.64^{\mathrm{a}}$ & $5.41^{\mathrm{a}}$ & $6.05^{\mathrm{a}}$ & $10.70^{\mathrm{a}}$ \\
\hline & & S.E. & 0.03 & 0.29 & 0.27 & 1.0 \\
\hline & \multirow[t]{2}{*}{ ALT-711 } & Mean & $0.79^{\mathrm{a}}$ & $4.84^{\mathrm{ab}}$ & $5.63^{\mathrm{a}}$ & $13.96^{\mathrm{a}}$ \\
\hline & & S.E. & 0.14 & 0.47 & 0.59 & 1.26 \\
\hline & \multirow[t]{2}{*}{ A-Mat } & Mean & $1.78^{\mathrm{b}^{*}}$ & $4.23^{b^{*}}$ & $6.01^{\mathrm{a}}$ & $29.31^{\mathrm{b}^{*}}$ \\
\hline & & S.E. & 0.19 & 0.09 & 0.26 & 1.98 \\
\hline \multirow[t]{6}{*}{ Semimembranosus } & \multirow[t]{2}{*}{ Control } & Mean & $0.23^{\mathrm{a}}$ & $4.08^{\mathrm{a}}$ & $4.31^{\mathrm{a}}$ & $5.46^{\mathrm{a}}$ \\
\hline & & S.E. & 0.01 & 0.37 & 0.38 & 0.27 \\
\hline & \multirow[t]{2}{*}{ ALT-711 } & Mean & $0.35^{\mathrm{a}}$ & $4.21^{\mathrm{a}}$ & $4.56^{\mathrm{a}}$ & $7.60^{\mathrm{a}}$ \\
\hline & & S.E. & 0.05 & 0.19 & 0.24 & 0.78 \\
\hline & \multirow[t]{2}{*}{ A-Mat } & Mean & $0.66^{\mathrm{b}^{*}}$ & $3.81^{\mathrm{a}}$ & $4.47^{\mathrm{a}}$ & $14.78^{\mathrm{b}^{*}}$ \\
\hline & & S.E. & 0.1 & 0.12 & 0.1 & 2.18 \\
\hline \multirow[t]{6}{*}{ Semitendinosus } & Control & Mean & $1.36^{\mathrm{a}}$ & $5.31^{\mathrm{a}}$ & $6.67^{\mathrm{a}}$ & $20.57^{\mathrm{a}}$ \\
\hline & & S.E. & 0.06 & 0.36 & 0.38 & 1.23 \\
\hline & Alt-711 & Mean & $1.29^{\mathrm{a}}$ & $5.15^{\mathrm{a}}$ & $6.44^{\mathrm{a}}$ & $20.03^{\mathrm{a}}$ \\
\hline & & S.E. & 0.07 & 0.31 & 0.38 & 0.27 \\
\hline & A-Mat & Mean & $1.94^{\mathrm{b}^{*}}$ & $4.65^{\mathrm{a}}$ & $6.59^{\mathrm{a}}$ & $29.52^{\mathrm{b}^{*}}$ \\
\hline & & S.E. & 0.08 & 0.22 & 0.16 & 1.74 \\
\hline
\end{tabular}

${ }^{\mathrm{a}-\mathrm{b}}$ Means within the same column and muscle with different superscript are different $\left(\mathrm{p}<0.05^{*}\right.$ and $\left.\mathrm{p}<0.10^{* *}\right) . \mathrm{C}=\mathrm{Control}$, Alt-711=Treated, A-mat. =A-maturity. 
While there was not a significant increase in total muscle collagen with age, with the exception of supraspinatus, collagen solubility strongly decreased with age semitendinossus, $\left(\mathrm{R}^{2}=>0.95\right)$; triceps brachii $\left(\mathrm{R}^{2}=0.99\right)$; biceps femoris $\left(\mathrm{R}^{2}=0.99\right)$; longissimus lumborum $\left(\mathrm{R}^{2}=0.92\right)$; longissimus thoracis $\left(\mathrm{R}^{2}=0.98\right)$; and semimembranosus $\left(\mathrm{R}^{2}=0.99\right)$. The correlation for the supraspinatus was weaker with increasing chronological age $\left(\mathrm{R}^{2}=0.36\right)$ (Figure 4-8).

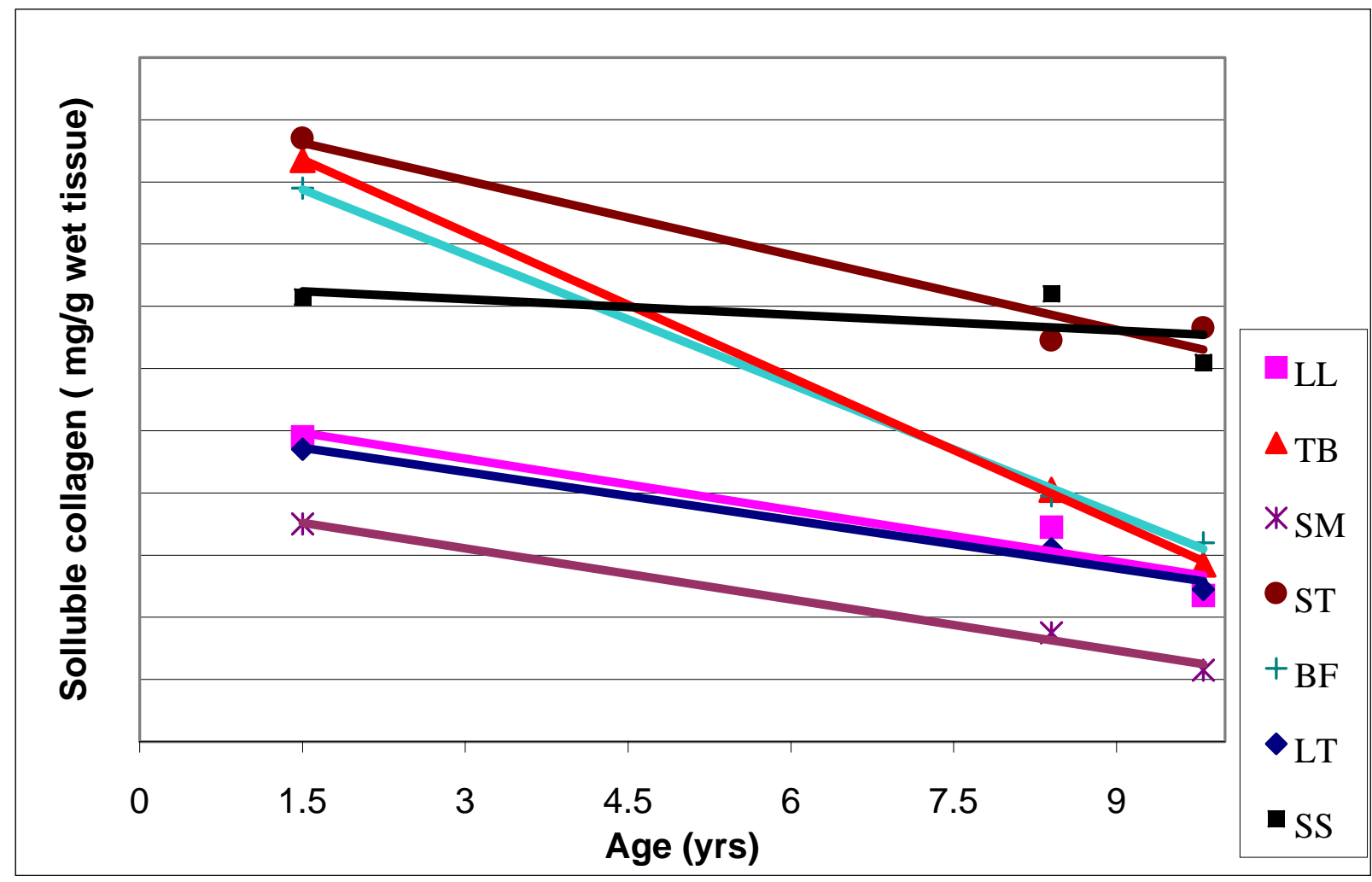

Figure 4-8. Relationship between soluble collagen and age. Each sign represent the mean $(n=5)$ in the muscles of A-maturity $=1.5$ years, Alt- $711=8.4$ years, Control $=9.8$ years. $\mathrm{LT}=$ Longissimus thoracis, $\mathrm{LL}=$ Longissimus lumborum, $\mathrm{TB}=$ Triceps brachii, $\mathrm{SS}=$ Supraspinatus, $\mathrm{ST}=$ Semitendinosus, $\mathrm{BF}=$ Biceps femoris, $\mathrm{SM}=$ Semimebranosus.

Semitendinosus of A-maturity had the highest total amount of soluble collagen (1.94 $\mathrm{mg} / \mathrm{gr})$ followed by triceps brachii muscle $(1.87 \mathrm{mg} / \mathrm{gr})$ and biceps femoris $(1.78 \mathrm{mg} / \mathrm{gr})$. However, triceps brachii had the lowest shear force $(3.67 \mathrm{~kg})$, while biceps femoris had 
the highest shear force $(8.06 \mathrm{~kg})$. Indeed, there was an appearant Alt-711 treatment effect on soluble collagen content. Soluble collagen content for all the muscles was higher, however not significant ( $p>0.10$ ) for Alt-711 treated animals compared to control animals (Figure 4-9). Although soluble collagen content was higher for supraspinatus of Alt-711 treated animals compared to A-maturity and Control animals (Figure 4-9).

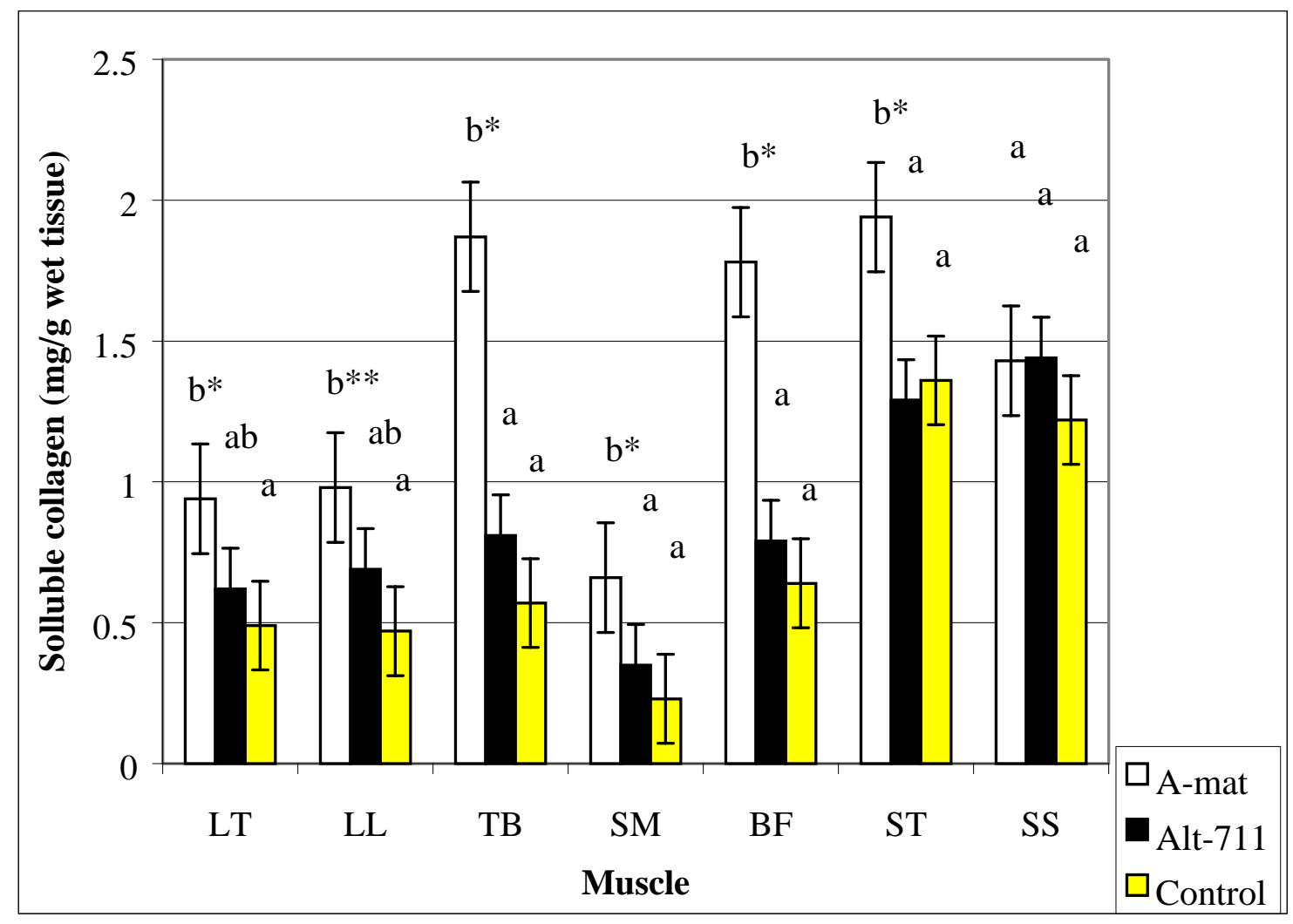

Figure 4-9. Soluble collagen content as function of muscle and treatment. ${ }^{\mathrm{a}-\mathrm{b}}$ Means within same muscle with different superscript are different $\left(\mathrm{p}<0.05^{*}\right.$ and $\left.\mathrm{p}<0.10^{* *}\right)$. Each bar represents the mean $(\mathrm{n}=5) \pm \mathrm{SEM}$. LT=Longissimus thoracis, $\mathrm{LL}=$ Longissimus lumborum, $\mathrm{TB}=$ Triceps brachii, $\mathrm{SS}=$ Supraspinatus, $\mathrm{ST}=$ Semitendinosus, $\mathrm{BF}=\mathrm{Biceps}$ femoris, $\mathrm{SM}=$ Semimembranosus. $\mathrm{C}=$ Control, Alt-711=Treated, A-mat.=A-maturity. 


\subsubsection{Soluble collagen percentage}

Soluble collagen percentage was marginally increased when cattle were treated with Alt-711 (5 mg/kg, i. m.) compared to the control animals (Figure 4-10), although the results were not significant $(\mathrm{p}>0.10)$. Longissimus thoracis, and semitendinosus had the highest soluble collagen percentage compared to the remaining muscles (Figure 4$10)$.

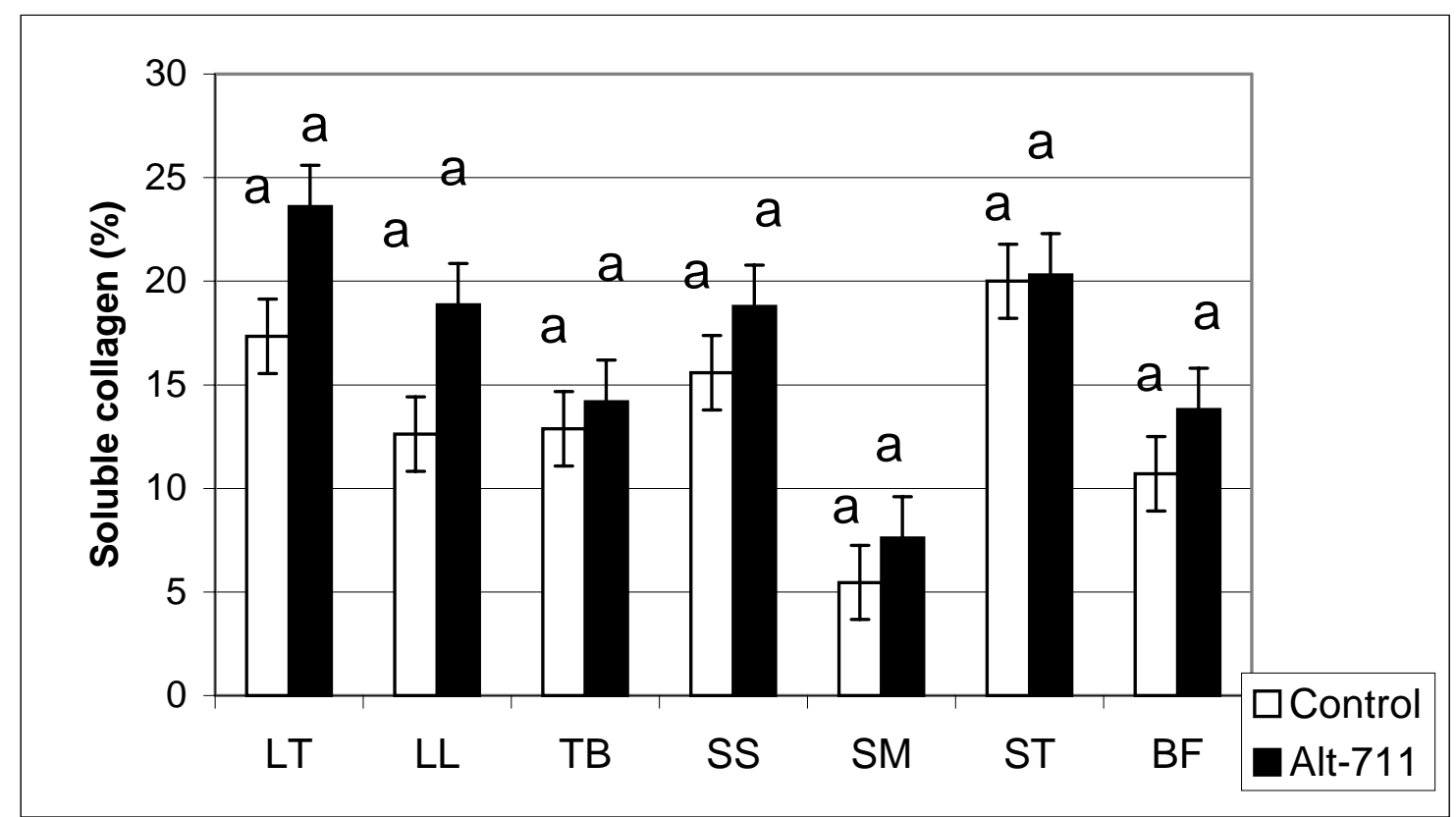

Figure 4-10. Effect of Alt-711 on the percentage of soluble collagen. Each bar represents the mean $(\mathrm{n}=5) \pm$ SEM $^{\mathrm{a}-\mathrm{b}}$ Means within same muscle with same superscript are not different $(\mathrm{p}<0.10)$. $\mathrm{LT}=$ Longissimus thoracis, $\mathrm{LL}=$ Longissimus lumborum, $\mathrm{TB}=$ Triceps brachii, $\mathrm{SS}=$ Supraspinatus, $\mathrm{ST}=$ Semitendinosus, $\mathrm{BF}=$ Biceps femoris, $\mathrm{SM}=$ Semimebranosus. Alt-711=Treated, $\mathrm{C}=$ Control.

The soluble collagen percentage for A-maturity group was significantly higher $(\mathrm{p}<0.05)$ for longissimus thoracis, biceps femoris, semimembranosus, and semitendinosus, triceps brachii and $(\mathrm{p}<0.10)$ for longissimus lumborum and 
supraspinatus compared to control and ALT-711 treated animals (Figure 4-11). The soluble collagen percentage for supraspinatus and longissimus lumborum was not different $(\mathrm{p}>0.10)$ for A-maturity and Alt-711 treated animals. Muscles with high percentage of soluble collagen were also the most tender such as triceps brachii (33.06 $\%$ vs $3.67 \mathrm{~kg}$ ) and longissimus thoracis ( $34.07 \%$ vs $4.08 \mathrm{~kg}$ ) within A-maturity group.

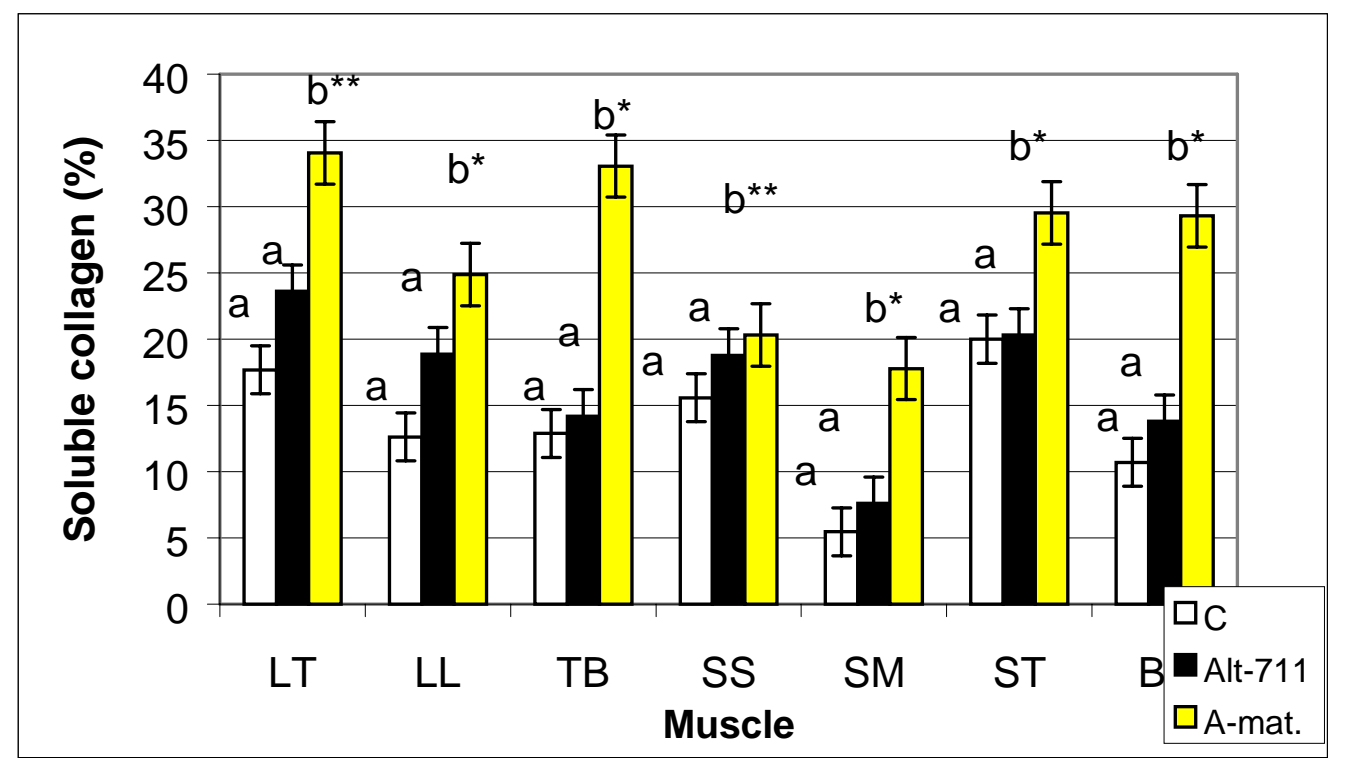

Figure 4-11. Soluble collagen percentage and treatment groups. Each bar represent the mean $(\mathrm{n}=5) \pm$ SEM. ${ }^{\mathrm{a}-\mathrm{b}}$ Means within same muscle with different superscript are different $\left(\mathrm{p}<0.05^{*}\right.$ and $\left.\mathrm{p}<0.10^{* *}\right)$. LT=Longissimus thoracis, $\mathrm{LL}=$ Longissimus lumborum, $\mathrm{TB}=$ Triceps brachi, $\mathrm{SS}=$ Supraspinatus, $\mathrm{ST}=$ Semitendinosus, $\mathrm{BF}=\mathrm{Biceps}$ femoris, $\mathrm{SM}=$ Semimebranosus. Alt-711=Treated, $\mathrm{C}=$ Control, A-mat.=A-maturity.

Muscle with the highest soluble collagen percentage was longissimus thoracis (34.07\%), and the muscle with the lowest percentage was semimbranosus (7.60) for Amaturity. For Alt-711 treated animals the highest soluble collagen percentage was found in longissimus thoracis $(23,62 \%)$ and the lowest in semimembranosus $(7.60 \%)$, while for control animals for the same muscles the soluble collagen percentages were $17.34 \%$ and $5.46 \%$. When the muscles were ranked based on the percentage of soluble collagen 
in the A-maturity group, the order from highest to lowest was

$\mathrm{LT}>\mathrm{TB}>\mathrm{ST}>\mathrm{BF}>\mathrm{LL}>\mathrm{SS}>\mathrm{SM}$. Simple Pearson correlation coefficient revealed a negative relationship between soluble collagen percentage and tenderness for all three treatments for longissimus thoracis. A strong negative relationship was found for the control animals $\mathrm{R}^{2}=-0.47$, a weak one for Alt-711-treated animals $\mathrm{R}^{2}=-0.21$, and for A-maturity group correlation coefficient was $\mathrm{R}^{2}=-0.27$.

The percentage of soluble collagen A-maturity vs E maturity animals was significantly higher $(\mathrm{p}<0.05)$ for longissimus thoracis, semitendinosus, semimebranosus, triceps brachii, and biceps femoris and $(\mathrm{p}<0.10)$ for longissimus lumborum and not significant ( $p>0.10)$ supraspinatus for the linear contrast old vs A-mat (Table 4-9).

Table 4-9. Orthogonal contrasts

\begin{tabular}{|c|c|c|c|c|c|c|c|c|}
\hline & & LT & $\mathrm{TB}$ & SS & ST & $\mathrm{BF}$ & LL & SM \\
\hline \multirow[t]{5}{*}{ Old vs A-mat. } & $\mathrm{SF}$ & $*$ & * & $*$ & $*$ & * & ns & ns \\
\hline & Total Coll. & ns & ns & ns & ns & ns & ns & ns \\
\hline & Insol. Coll. & ns & $* *$ & $* *$ & $\mathrm{~ns}$ & $*$ & ns & ns \\
\hline & Sol. Coll. & $*$ & $*$ & ns & $*$ & $*$ & $* *$ & $*$ \\
\hline & Sol. Coll \% & $*$ & $*$ & ns & $*$ & $*$ & ns & $*$ \\
\hline \multirow[t]{3}{*}{ C vs ALT-711 } & Total Coll. & ns & $*$ & ns & $\mathrm{ns}$ & ns & ns & ns \\
\hline & Insol. Coll. & ns & $*$ & ns & $\mathrm{ns}$ & ns & ns & ns \\
\hline & \multicolumn{8}{|c|}{ SF; Sol. Coll.; Sol. Coll. \% not significant $(\mathrm{p}>0.10)$} \\
\hline
\end{tabular}

Old= Control and Alt-711; C=Control; Alt-711= Alt-711 treated animals; Amat.=A-maturity; $\mathrm{SF}=$ Shear force; Means are significantly different at $\mathrm{p}<0.05^{*}$ and $\mathrm{p}<0.10^{* *} ; \mathrm{ns}=$ not significantly different at $\mathrm{p}>0.10$. 


\subsubsection{Sarcomere length}

Sarcomere length in the longissimus thoracis for the A-maturity animals was significantly longer $(\mathrm{p}<0.05)$ compared to the Alt-711 treated group. Also, biceps femoris for the A-maturity group had significantly longer sarcomere length $(\mathrm{p}<0.05)$ compared to the control group and $(\mathrm{p}<0.10)$ compared to ALT-711 treated group (Table 4-10). Sarcomere length for longissimus lumbroum for A-maturity animals was $1.97 \mu \mathrm{m}$ and for biceps femoris was $1.81 \mu \mathrm{m}$. In our study sarcomere length was negatively correlated with longissimus thoracis shear force for the control $\left(\mathrm{R}^{2}=-0.62\right)$ and Amaturity animals $\left(\mathrm{R}^{2}=-0.53\right)$, and weakly positive correlated for ALT-711 treated animals $\left(\mathrm{R}^{2}=0.09\right)$ (Table 4-10). When biceps femoris was taken in consideration, the shear force positively correlated $\left(\mathrm{R}^{2}=0.67\right)$ with sarcomere length for the A-maturity, and negatively correlated for the control $\left(R^{2}=-0.36\right)$ and Alt-711 treated animals $\left(R^{2}=-\right.$ 0.07). Also, a negative Pearson correlation coefficient was found between sarcomere length and back fat thickness for Control $\left(\mathrm{R}^{2}=0.17\right)$ and Alt-711 treated animals $\left(\mathrm{R}^{2}=0.05\right)$ and a weak for A-maturity animals $\left(\mathrm{R}^{2}=0.02\right)($ Table $4-10)$.

Table 4-10. Mean sarcomere length and Pearson correlation coefficient $\left(\mathbf{R}^{2}\right)$ between sarcomere length, tenderness (SF), and back fat thickness.

\begin{tabular}{|llcc|c|c|}
\hline & & Sarcomere length $(\mu \mathbf{m})$ & & & \\
& Treatment & Mean & S.E. & $\mathbf{R}^{\mathbf{2}}$ & $\mathbf{R}^{\mathbf{2}}$ \\
& Control & $1.87^{\mathrm{ab}}$ & 0.05 & -0.62 & -0.17 \\
& ALT-711 & $1.83^{\mathrm{a}}$ & 0.01 & 0.09 & -0.05 \\
& A-Mat. & $1.97^{\mathrm{b} *}$ & 0.05 & -0.53 & 0.02 \\
Biceps femoris & Control & $1.7^{\mathrm{a}}$ & 0.01 & -0.36 & 0.81 \\
& ALT-711 & $1.74^{\mathrm{a} * *}$ & 0.02 & -0.07 & 0.30 \\
& A-Mat. & $1.81^{\mathrm{b} *}$ & 0.03 & 0.67 & -0.34 \\
\hline
\end{tabular}

${ }^{\mathrm{a}-\mathrm{b}}$ Means $(\mathrm{n}=5) \pm$ SEM with different superscript are different $\left(\mathrm{p}<0.05^{*}\right.$ and $\left.\mathrm{p}<0.10^{* * *}\right)$. $\mathrm{C}=$ Control, ALT-711 =Treated, A-mat=A-maturity, $\mathrm{LT}=$ longissimus thoracis, $\mathrm{BF}=$ biceps femoris. 
Longissimus thoracis had a longer sarcomere length and lower shear force for Amaturity compared to control and Alt-711 animals. Also, when sarcomere length was longer, tenderness was higher regardless of muscle type (Figure 4-12).

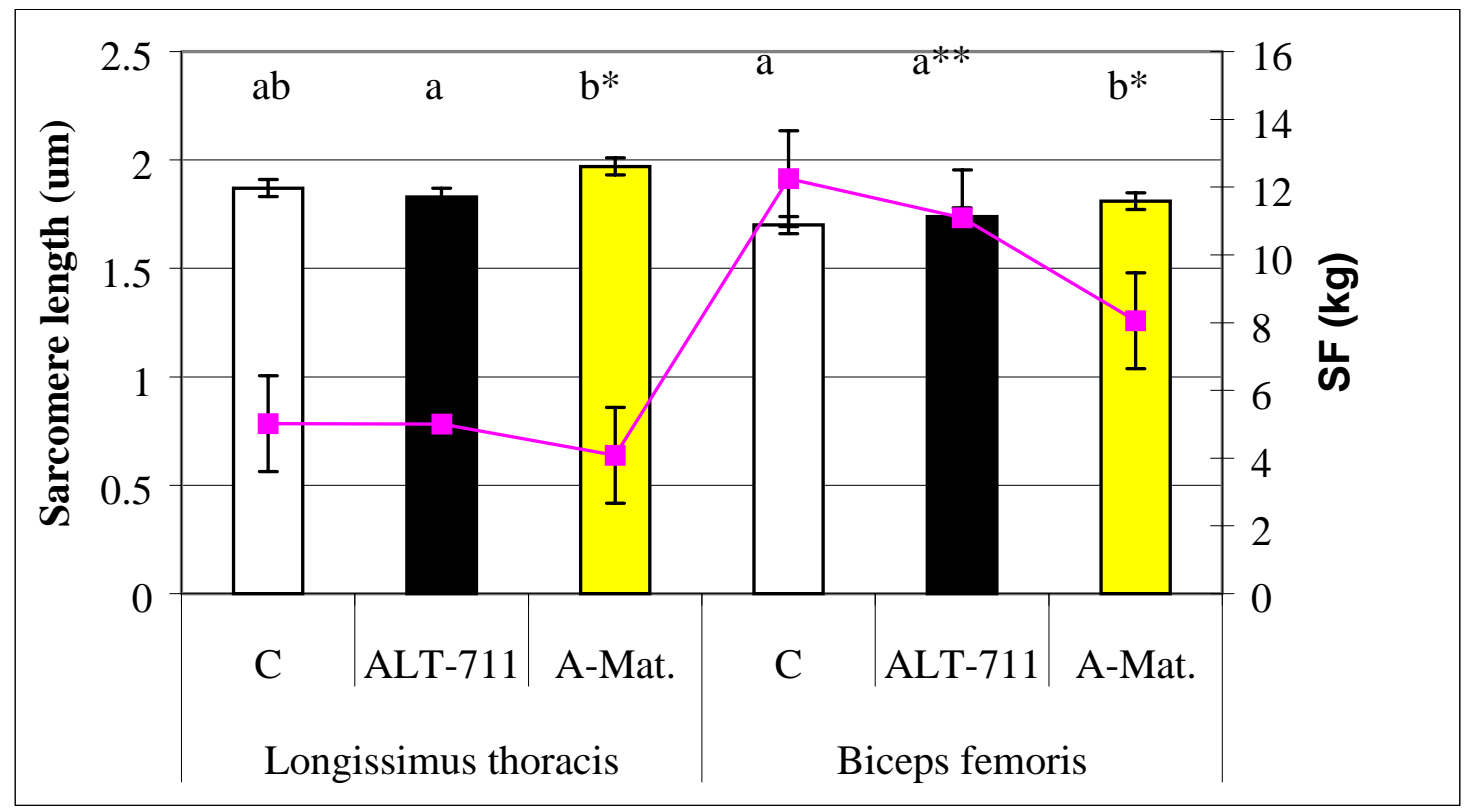

Figure 4-12. Relationship between sarcomere length and tenderness (shear force). $\mathrm{SF}=$ Shear force ${ }^{\mathrm{ab}}$ Means with different superscript within same muscle are different $\left(\mathrm{p}<0.05^{*}\right.$ and $\left.\mathrm{p}<0.10^{* * *}\right)$. Each bar represents the mean $(\mathrm{n}=5) \pm$ SEM. $\mathrm{C}=$ Control, ALT$711=$ treated, A-mat=A-maturity. $\mathrm{LT}=$ longissimus thoracis, $\mathrm{BF}=$ biceps femoris.

\subsubsection{Plasma Glucose}

Plasma glucose concentrations were not different ( $>>0.05$ ) between groups; however the control animals had a lower plasma glucose concentration $(\mathrm{mg} / \mathrm{dL})(101 \mathrm{vs}$ 107 vs 107) compared to ALT-711 treated and A-maturity animals (Table 4-11). 
Table 4-11. Means and glucose ranges for treatment groups ( $n=5$ per group).

\begin{tabular}{|lccccc|}
\hline & \multicolumn{5}{c|}{ Glucose $(\mathrm{mg} / \mathrm{dL})$} \\
\hline Treatment & Mean & Min & $\operatorname{Max}$ & S.E. & S.D. \\
\hline Control & $101^{\mathrm{a}}$ & 79 & 128 & 9.9 & 19.8 \\
ALT-711 & $107^{\mathrm{a}}$ & 79.5 & 142 & 13.7 & 27.4 \\
A-Maturity & $107^{\mathrm{a}}$ & 99.5 & 115 & 2.4 & 5.41 \\
& & & & & \\
\hline
\end{tabular}

${ }^{\mathrm{a}}$ Means with same superscript are not different $(\mathrm{p}<0.05)$.

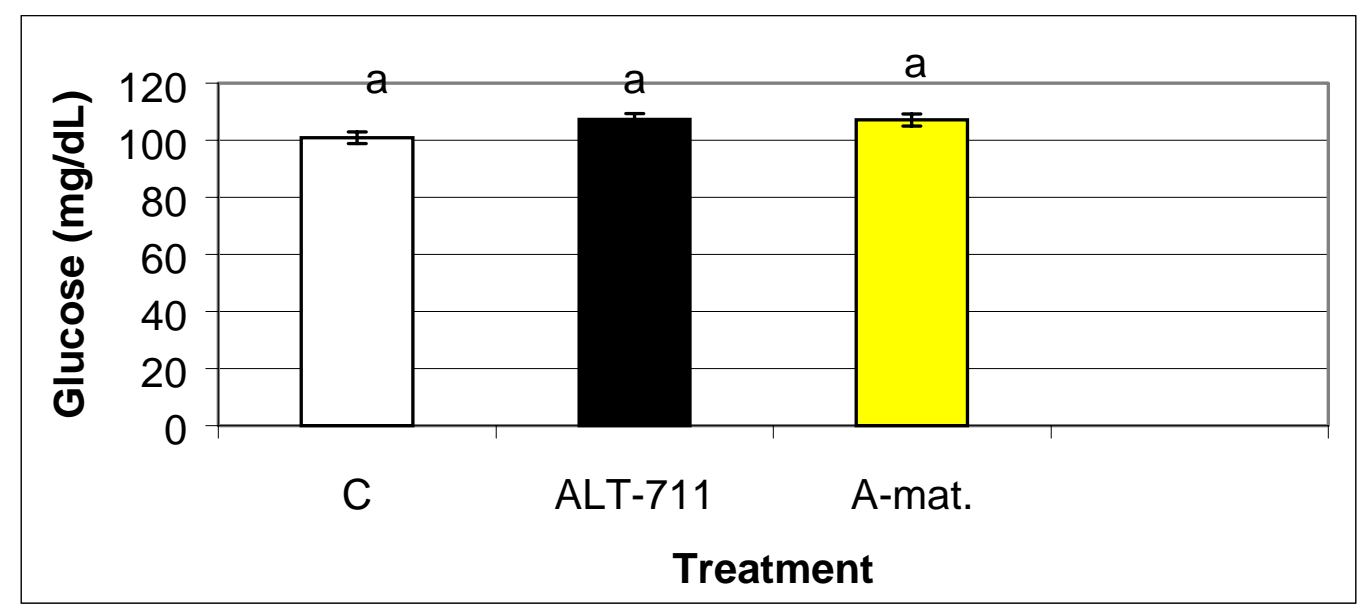

Figure 4-13. Plasma glucose concentrations. ${ }^{a}$ Means with same superscript are not different $(\mathrm{p}<0.05)$. Each bar represents the mean $(\mathrm{n}=5) \pm \mathrm{SE}$ M. C=Control, Alt$711=$ Treated, A-mat.=A-maturity

\section{Discussion}

Body weight. ALT-711 did not result in significant body weight changes.

Wolffenbuttel et al., (1998) also reported that the administration of ALT-711 to rats did not affect body weights. 
Color. The meat color is dependent on the concentration of myoglobin $(\mathrm{Mg})$. Myoglobin can exist in three forms: the purple (reduced) deoxymyoglobin, the cherryred (oxygenated) oxymyoglobin (MbO) and greyish-brown (oxidized) metmyoglobin (MMb) (Van Laack et al., 1990). However, pigmentation also depends on muscular activity, animal age, species, feeding system (Giddings, 1977; Honikel, 1997) . In addition to the chemical state of $\mathrm{Mb}$, physical-chemical factors such as $\mathrm{pH}$, waterholding capacity, and muscle structure affect the perceived color (Lawrie, 1979). O'Keefe et al. (1982) stated that the most significant factor affecting color stability of beef muscle appear to be their enzymatic activity, while Atkinson et al. (1969) reported that the rate of oxygen consumption decreases with age of meat post mortem due to depletion of substrates, coenzymes, and degradation of enzymes involved in mitochondria respiration. Also, a decrease in $\mathrm{pH}$ and temperature causes a decrease in oxygen consumption. In our study, muscles of the A-maturity animals such as longissimus thoracis, triceps brachii, biceps femoris, and semimembranosus were significantly lighter $(\mathrm{p}<0.05$ and $\mathrm{p}<0.10)$ compared to the control and Alt-711 treated animals. The differences in $\mathbf{L} *$ value in our study are due to maturity factor (A-mat vs E-maturity); for A-maturity $\mathbf{L} *$ values were significantly higher $(\mathrm{p}<0.05)$ for biceps femoris, semimembranosus, and $(\mathrm{p}<0.10)$ for triceps brachii and longissimus lumborum. MacDougall et al. (1972) reported that when darkness occurred its major cause was pigment concentration and high upH. When $\mathrm{pH}$ is high, muscle proteins are above isoelectric point and most of the water is associated with them. Also, high $\mathrm{pH}$ alters the absorption characteristics of the myoglobin, so the surface will not scatter light, while at low $\mathrm{pH}$ myoglobin is prone to oxidation and its structure is open and scatters light 
(Lawrie, 1991). Bhattacharya (1988) reported that $\mathbf{L}^{*} \mathbf{a}^{*} \mathbf{b}^{*}$ values decreased as frozen storage time increased. The freezing process causes changes on the structure of the muscle. The morphology of ice in the frozen tissue and the size and distribution of ice crystals formed in the intra-, extracellular spaces cause changes in water-holding capacity, texture, and surface color. Muscle numerical $\mathbf{L}^{*}$ values in this study disagree with those of Boleman et al. (1996), who reported higher numerical values for $\mathbf{L}^{*}$ and $\mathbf{a}^{*}$ for E-maturity animals and lower numerical $\mathbf{b}^{*}$ values. These changes may be due to storage time. For this study, the samples were stored for a period of 5-month prior analysis, thus this disagreement might be explained by storage effect on color, effect manifested through lower $\mathbf{L}^{*}$ values. Brooks (1948) showed that browning occurred much more rapidly at low relative humidity, greater dehydration, globin denaturation, and metmyoglobin formation. Myoglobin stability depends on the interaction of the heme group with the globin chains (Dickerson and Geiss, 1983). As with any biological macromolecule, myoglobin functionality depends on environmental conditions such as temperature and $\mathrm{pH}$. Extremes of these conditions affect essential structure of macromolecules and their function (Garrett and Grisham, 1999). Hunt et al. (1999) stated that susceptibility to denaturation and color change depends on $\mathrm{pH}$, ligand (oxygen) bound to the heme, redox state of the iron, and the stability of globin chains ( $\alpha$-chain protein).

$\boldsymbol{p H}$. During muscle conversion to meat, anaerobic glycolysis causes $\mathrm{pH}$ to decline. The rate and the extent of $\mathrm{pH}$ decline are major determinants of meat quality. Warner (1994) and Pearson and Young (1989) reported that a higher ultimate $\mathrm{pH}(\mathrm{upH})$ is associated with darker color, reduced drip loss and increased firmness. Data in our study 
shows (Figure 4-6) that muscles of A-maturity animals had a lower cooked muscle $\mathrm{pH}$ and a higher $\mathbf{L}^{*}$ values, while for control animals, muscles with higher cooked $\mathrm{pH}$ were darker for the semimembranosus, supraspinatus, and biceps femoris. ALT-711 treated animals had the lowest $\mathbf{L}^{*}$ for longissimus lumborum and semitendinosus muscles. At high $\mathrm{pH}$, muscle proteins are above their iso-electric point, much of the water will be associated with the proteins and the fibres will be tightly packed and will be a barrier to diffusion. In such a case, oxymyoglobin content is small, while purple-red myoglobin predominates, and the meat appears darker. Among the factors which influences muscle $\mathrm{pH}$ is the muscle glycogen level at animal death. Lactate formation reduces $\mathrm{pH}$. However, muscles with the same lactate level have a different $\mathrm{pH}$ (Van Laack et al., 2000). Lawrie (1991) stated that different muscles have different buffering capacity or differ in the concentration of strong ions such as $\mathrm{Mg}^{2-} \mathrm{Ca}^{2+}, \mathrm{Cl}^{-}$, while Bendal et al. (1957) stated that $\mathrm{pH}$ decline of postmortem muscle is slowed by buffering effect of ammonia generated from deamination of adenosine monophaspate (AMP).

Shear force. Muscles of A-maturity animals had a lower shear force than those of E -maturity animals. Differences in meat toughness are caused by the maturation process in connective tissue. Bailey (1984) stated that the maturation process leads to stabilization of the collagen network through multivalent crosslinking of collagen molecules. Age-related changes in the shear force values are consistent with those reported by Smith et al. (1982), McKeith et al. (1985), and Zinn et al. (1970) for the triceps brachii, and by Tatum et al. (1980), Cranwell et al. (1996), and Wheeler et al. (1996 and 1997) for the longissimus thoracis, longissimus lumborum, semimembranosus, and semitendinosus muscles. Shackelford et al. (1995) reported that 
the longissimus muscle from yearling heifers was similar in shear force to those from 2yr old cows. Zinn et al. (1970) and Gramlich and Thalman (1930) reported that heifers might mature at a younger chronological age. Jeremiah (1978) and Smith et al. (1984) reported that as chronological age increases, meat tenderness decreases, and our data are consistent with this observation (Figure4-5). Muscle tenderness decreased with increasing chronological age; a strong relationship was found between age and tenderness for biceps femoris $\left(\mathrm{R}^{2}=0.94\right)$, semimembranosus $\left(\mathrm{R}^{2}=0.81\right)$, longissimus lumborum $\left(\mathrm{R}^{2}=0.77\right)$, supraspinatus $\left(\mathrm{R}^{2}=0.63\right)$, and a weak relationship for longissimus thoracis $\left(\mathrm{R}^{2}=0.32\right)$, triceps brachii $\left(\mathrm{R}^{2}=0.37\right)$, and semitendinosus $\left(\mathrm{R}^{2}=0.40\right)$.

Differences in muscle tenderness might be explained by differences in physiological maturity of the animal and muscle function. However, contradictory data exists regarding the order of tenderness of muscles. Palson and Verges (1952) and McKeekan (1940) indicated that the order of the maturity of the muscles from earliest to latest should be triceps brachii, semimembranosus, and longissimus. While Hiner and Hankis (1950) reported that the order of decreasing tenderness was longissimus, triceps brachii, and semimembranosus. Zinn et al. (1970) reported that the triceps brachii was the least mature muscle, and our data agree with his results regarding shear force values. Age-related changes in tenderness are due to collagen maturation and crosslink formation. Bailey (1984) stated that the maturation process leads to stabilization of the collagen network through multivalent crosslinking of collagen molecules. Eventhough, we did not isolate mature crosslinks, the data suggest that as animal matured, collagen networks becomes increasingly stabilized by these crosslinks. This stabilized collagen is accompanied by a reduction of soluble collagen content (Cross et al., 1984; Augustini 
and Temisan, 1985), and by enhancement in mechanical stability (Bernal and Stanley, 1987). Moriguchi and Fujimote (1978) indicated that crosslinks formation is an essential step of growth in order to provide the need for greater mechanical strength as size increases.

Collagen. Age is the major factor contributing to collagen crosslinking. Augustini and Temisan (1985) stated that muscle collagen content from young and old animals differed slightly.

Total collagen. In this study total muscle collagen of A-maturity animals was not different $(p>0.05)$ compared to the control and ALT-711 treated animals. Total collagen content for longissimus lumbroum, triceps brachii, and supraspinatus of A-maturity animals is in agreement with those reported by Johnson et al. (1988). However, total collagen content of longissimus lumborum (mg/g) for A-maturity was the highest compared to control and ALT-711 treated animals (3.77 vs 3.72 vs 3.73), respectively. Reagan et al. (1976) also reported higher total collagen content for longissimus lumborum from A-maturity animals compared to E-maturity animals (mg/g) (5.8 vs 5.1), respectively. The positive Pearson correlation coefficient between longissiumus thoracis shear force and total collagen for control aged animals $\left(\mathrm{R}^{2}=0.39\right)$ and a negative one for young animals $\left(\mathrm{R}^{2}=-0.18\right)$ in this study is in agreement with Zepeda et al. (1995) who reported a higher correlation $\mathrm{R}^{2}=0.79$ for old animals and $\mathrm{R}^{2}=0.16$ for young animals. Mc Keith et al. (1985) reported a negative correlation $\left(\mathrm{R}^{2}=-0.36\right)$ between overall muscle tenderness and total collagen for young animals. Cross et al. (1973) found a negative simple correlation coefficient and panel tenderness of longissimus dorsi $\left(\mathrm{R}^{2}=-\right.$ 0.42). 
Insoluble collagen. Even though total collagen content of young animals was not significantly different compared to aged animals, insoluble collagen content was higher $(\mathrm{p}<0.05)$ for aged animals. Veis (1966) stated that 2 factors were essential involved in the structure stabilization such as fiber wave and intermolecular crosslinking. Therefore collagen intermolecular crosslinking occurred in mature, insoluble collagaen. Shear force strongly positive correlated with insoluble collagen content of longissimus thoracis, revealing Pearson correlation coefficient for control of $\mathrm{R}^{2}=0.41$ and $\mathrm{R}^{2}=-0.32$ for Alt-711 treated animals. Whereas, shear force negative correlated with insoluble collagen content $\left(\mathrm{R}^{2}=-0.01\right)$ for A-maturity animals. Zepeda et al., (1995) reported that shear force positive correlated with longissimus thoracis insoluble collagen $\left(\mathrm{R}^{2}=0.81\right)$ for aged cattle, and weakly for A-maturity animals $\left(\mathrm{R}^{2}=0.15\right)$. Piez (1966) reported that intra- and intermolecular crosslinking proceded in a continuous process during collagen formation and maturation.

Soluble collagen. Collagen solubility decreased with increasing age. Bailey and Shimokomaki (1971) demonstrated that reducible crosslinks of collagen are transformed into more stable non-reducible mature crosslinks (pyridinolines) as chronological age increases. Data from this study shows a decrease in collagen solubility as cattle mature (A-maturity vs E-maturity; Figure 4-8), and also a decrease in meat tenderness (Figure 4-6). These data are in agreement with those of Hill (1966) and Dikeman (1971) in that muscle collagen solubility decreased with increasing age. Also, soluble collagen content and shear force of longissimus thoracis revealed a negative Pearson correlation coefficient for A-maturity, $\mathrm{R}^{2}=-0.23$; control, $\mathrm{R}^{2}=-0.13$; and for Alt $-711, \mathrm{R}^{2}=-0.45$. 
Zepeda et al. (1995) reported a negative Pearson correlation for aged animals $\mathrm{R}^{2}=-0.08$, and a positive for young animals $\mathrm{R}^{2}=0.11$.

The decrease in collagen solubility of muscles from 1.5 to 9.8 years is likely due to increased non-reducible collagen crosslinks; these crosslinks increase the mechanical strength of intramuscular collagen, thereby causing tougher meat.

The negative correlation between soluble collagen and back fat thickness for Amaturity and control, suggests that when fat thickness was high, the amount soluble collagen was low. Cassens (1977) stated that the physiological or biochemical properties of muscle are a reflection of the proportion of muscle fiber types present. For this reason the fat or collagen characteristics of a muscle are a reflection of the percentage of red vs white muscle fiber types. Beatty et al. (1967) reported that red muscles of rhesus monkeys contained approximately one-half as much collagen as white muscle. In this study total collagen was higher for red muscles such as biceps femoris and semitendinosus compared to the white longissimus muscle. This observation reflects the physiological function of the muscle groups. Longissimus muscle supports vertebral column and contributes to the elasticity of the body during forward and backward movement; whereas, the biceps femoris and semitendinosus are used a lot for the motor function of the body. The amount of insoluble collagen for these two red muscles was approximately double that of the white muscle. This difference is necessary for the requirements associated with locomotion. For this reason, collagen fibres of these two muscles are more crosslinked in order to confer mechanical support. In support of this view, Eyre et al. (1984) reported a correlation between muscle function and cross- 
linkage of connective tissue. In this study we show that tenderness is also a function of the physiological role of the muscles.

Soluble collagen percentage $(\%)$ was significantly higher $(\mathrm{p}<0.05)$ for A-mat. longissimus thoracis, triceps brachii, biceps femoris, semimebranosus, and semitendinosus, and $(\mathrm{p}<0.10)$ for A-mat. longissimus lumborum, and supraspinatus compared to control and ALT-711 treated animals. A-maturity animals, soluble collagen (\%) was and not different ( $\mathrm{p}>0.10)$ for longissimus lumbroum and supraspinatus compared to ALT-711 treated animals. The highest soluble collagen (\%) was found in the longissimus thoracis and the lowest in the semimembranosus of A-maturity animals. Similar data was reported by Seideman (1986). Cross et al. (1973) concluded that soluble collagen percentage was significantly related to the contribution of connective tissue components (elastin and collagen) to toughness as assessed by sensory panel. The negative Pearson correlation coefficient between shear force and soluble collagen percentage for longissimus thoracis for young $\left(\mathrm{R}^{2}=-0.27\right)$ and control and Alt-711 aged cattle $\left(R^{2}=-0.47\right.$ and $\left.R^{2}=-0.21\right)$ is in agreement with Reagen et al. (1976). When soluble collagen percentage decreased, shear force increased.

In this study, for control and Alt-711 treated animals as the amount of soluble collagen decreased, tenderness also decreased despite the fact that the amount of insoluble collagen was not different ( $\mathrm{p}>0.10$ ) for longissimus lumborum, semimbranosus, and semitendinosus muscles. In addition to collagen content contributions to meat quality, we must also consider the age-related nonenzymatic crosslinks contribution. Iqbal et al. (1999b) reported that nonenzymatic glucose collagen crosslinking (pentosidine) in muscle of broiler breeder hens, contributes to the decline in 
meat tenderness. Advanced glycation end products such as pentosidine are generated during glucose-derived crosslinked proteins, such as collagen, and accelerates the ageing of the affected tissues. Avery et al. (1996) showed that variation in the texture of longissimus lumborum of pork was unrelated to the concentration of the intramolecular crosslink, pentosidine. Brama et al. (1999) reported an increase in pentosidine with increasing age in equine articular collagen network. No data has been reported regarding the contribution of pentosidine to the toughness of beef in older cattle. However, these crosslinks may exist because of the longer half-life of collagen despite a normal glucose level. These nonenzymatic crosslink products crosslink with other collagen molecules and are postulated to be responsible for the changes associated with normal aging (Brownlee et al., 1988) as well as the pathophysiology of diabetic complications (Cefalu et al., 1995; Monnier, 1989).

Alt-711. The novel crosslink breaker compound, Alt-711 increased tendon collagen solubility of diabetic rats (Wolfunbutel et al., 1998). Soluble collagen content was higher from supraspinatus of Alt-711treated animals compared to A-maturity and control animals. However, in this study we report an increase in collagen solubility, however not significant ( $\mathrm{p}>0.10)$. Wolfunbutel et al. (1998) reported a significant increase of collagen solubility; the differences between these two studies might be explained by a different species and tissues, as well as by different mode of administration of the drug. Nevertheless, glucose induced damage is not unique to the diabetic state. Even at normal levels of blood glucose there will be some degree of glycation and accumulation of glycation crosslinks over time that is associated with normal aging. 
Results from this study suggest that Alt-711 increases muscle collagen solubility of old cattle, and therefore may reduce/reverse collagen crosslinking.

However, this study shows that ALT-711 did not improve meat quality of aged cattle. More research is needed on Alt-711's effect in other species.

The large standard error for shear force, soluble, insoluble, and total collagen content, indicates that these traits are variable between animals. Reagan et al. (1976) and Cross et al. (1973) have reported similar trends in the variability of collagen solubility.

Sarcomere length. Sarcomere length is a measure of the muscle contraction state, and it is generally considered to be a significant factor contributing to tenderness (Locker, 1960). Sarcomere length for longissimus thoracis and biceps femoris of Amaturity animals was longer compared to control and ALT-711 treated animals. Smith et al., (1976) suggested that fatter animals produce more tender muscle because of the insulatory effect of fat in reducing the cold-shortening and/or in enhancing proteolysis. In our study A-maturity animals had a higher back fat thickness (cm) (1.09 vs 0.86 vs 0.91) compared to control and ALT-711 treated animals, respectively. A positive correlation between back fat thickness and sarcomere length for the longissimus thoracis of A-maturity animals and a negative correlation in control and ALT-711 treated animals was observed. Sarcomere length is also influenced by the method of carcass suspension. In our study carcasses were hung in a traditional manner. Herring et al. (1965b) reported a longer sarcomere length when the carcasses were hung by the aitch bone which was associated with increased tenderness. Our results agree with those reported by Mc Keith et al. (1985) and Herring et al. (1965b) for sarcomere length of Amaturity animals for both muscles. Values reported by Mc Keith for longissimus 
thoracis and biceps femoris are $2.10 \mu \mathrm{m}$ and $1.81 \mu \mathrm{m}$, respectively. Marsh (1977) cites two major structural reasons for variation in tenderness, collagen (connective tissue) and the contractile status especially the decrease in sarcomere length.

Plasma glucose. Kopper (1984) reported a normal plasma glucose of $62 \pm 8$ $\mathrm{mg} / \mathrm{dL}$ for the cattle. The higher levels observed in our study may be associated with the stress during pre-slaughter handling. Wood-Gush et al., (1975) described pre-slaughter treatment as one of the most stressful procedures endured by farm animals. Cockran and Corley (1991) found that plasma glucose concentrations were positively correlated with amount of struggle before slaughter. Comparative with other species, cattle plasma glucose concentrations in this study were 2.2 times lower than those of chickens, whose concentrations vary from $210 \mathrm{mg} / \mathrm{dl}$ to $260 \mathrm{mg} / \mathrm{dl}$ (Iqbal et al., 1999).

\section{Conclusions}

- ALT-711 treatment did not affect body weights of older cattle.

- Muscles of young animals were lighter (higher $\mathbf{L}^{*}$ ) compared to the muscle of old animals.

- Muscle tenderness of young animals (A-maturity) was significantly greater compared to old animals (E-maturity).

- Decreased collagen solubility with increasing age contributed to decreased muscle tenderness.

- As animal age increase, insoluble collagen content increases. 
- As cattle mature, collagen solubility decreases linearly and collagen becomes more crosslinked. These factors lead to decreased muscle tenderness.

- While the total muscle collagen content of young animals was not significantly different from old animals, soluble collagen was significantly higher.

- The crosslink breaker ALT-711, increased collagen solubility in mature animals.

- ALT-711 treatment did not improve muscle tenderness of aged cattle.

- Longissimus thoracis and biceps femoris muscles of young animals had a significantly longer sarcomere length, and were associated with lower shear force compared to Alt-711 and control animals.

- Plasma glucose of old animals was not different from that of young animals.

- ALT-711 may be an effective treatment to reduce age-related collagen crosslinking associated with normal aging.

- The results of this study do not support the use of ALT-711 to improve muscle tenderness in aged cattle.

- More research should be done on the mode of action of Alt-711 in species other than laboratory animals. 


\section{REFERENCES}

Asif, M., Egan, J., Vasan, S., Jyothirmayi, N., Masurekar, M., Lopez, S., Wiliams, C., Tores, R., Wagle, D., Ulrich, P., Cerami, A., Brines, M. 2000. An advanced glycation endproduct cross-link breaker can reverse age-related increase in myocardial stiffness. Proc. Natl. Academ. U. S. A. 97:2809-13.

Aberlee, E. D., Reeves, E. S., Judge, M. D., Hunlsey, R. E., Pery, T. W. 1981.

Palatability and muscle characteristics of cattle with controlled weight gain: time on a high-energy diet. J. Anim. Sci. 52:757-763.

Allain, J. C., Lelous, M., Bazin, S., Bailey, A. J., Delaunay, A. 1978. Isometric tension developed during heating of collagenous tissues. Relationships with collagen cross-linking. Biochim. Bioophys. Acta 533:147-155.

Allen, R. E., Merkel, R. A., and Young, R. B. 1979. Cellular aspects of muscle growth: myogenic cell proliferation. J. of Anim. Sci. 49:115-127.

Andersen, M. K., Caperna, T. S., and McCormick, R. J. 1992. Porcine Somatotropin (pST) alters intramuscular crosslinking of growing pigs. FASEB 9A: 1942.

Andreassen, T. T., Seyer-Hansen, K., and Bailey, A. J, 1981. Thermal stability, mechanical properties and reducible cross-links of rat tail tendon in experimental diabetes. Biochim. Biophys. Acta 677:313-317.

Ashmore, C.R., Tompkins, G., Doerr, L. 1971. Postnatal development of muscle fibre types in domestic animal. J. Anim. Sci. 31:37-41.

Atkinson, J.L., Follett, M. J., Ratciff, P. W. 1969. Post-mortem changes in the oxygen uptake and NAD content of lamb musclularis semimembranosus. Nature, 2231372-1373.

Augustini, C. and Temisan, V. 1985. Kollagen und Kollagenloslichkeit in verschiedenen Muskeln von Jungbullen in Abhangigkeit vom Alter. Mitteilungsblatt der Bundesanstalt fur Fleischforschung 90: 6673-6677.

Avery, N. C., Sims, T. J., Warkup, C., and Bailey, A. 1994. Collagen cross-linking in porcine $M$. longissimus lumborum: Absence of a relationship with variation in texture at pork weight. Meat Sci. 42:355-369.

Avery, N. C., Sims, T. J., Warkup, C. and Bailey, A. J. 1996. Collagen cross-linking in porcine $\mathrm{M}$. longissimus lumborum: Absence of a relationship with variation in texture at pork weight. Meat Sci. 42:355-369.

Avey, N. C. \& Bailey, A.J. 1995. An efficient method for the isolation of intramuscular collagen. Meat Sci. 41:97-105. 
Bailey, A. J. 1989. The chemistry of collagen cross-links and their role in meat texture. Proc. $42^{\text {nd }}$ Annual Reciprocal Meat Conference National Live Stock and Meat Board, Chicago, IL. 42:127-134.

Bailey, A. J. 1988. Connective tissue and meat quality. In: Proc. Intl. Congress Meat Sci. tech. PartA: 152-158, Brisbane, Australia.

Bailey, A. J. 1990. Proc. 42 ${ }^{\text {nd }}$ Reciprocal Meat Conference, Guelp, Canada 1989. National Live stock and Meat Board, Chicago, USA, p.127-134.

Bailey, A. J. and Light, N. D. 1985. Inter-molecular crosslinking in fibrotic collagen. In: Ciba Foundation Symposium 114, Pitman, London p:80-85.

Bailey, A. J. 1984. Recent Advances in the Chemistry of Meat. Special Publications No. 47:22-40. the Royal Society of Chemistry, London.

Bailey, A. J., and Light, N. D. 1989. Connective Tissue in Meat and Meat Products. Elsevier Appl. Sci., London.

Bailey, A. J., Etherington, D. J. 1980. Metabolism of collagen and elastin. Comp. Biochem. 19B:299-300.

Bailey, A. J., and Shimokomaki, M. 1971. Age related changes in the reducible crosslinks of collagen. FEBS Lett. 16:86-88.

Bailey, A. J., Lister, D., 1968. Thermally labile cross-links in native collagen. Nature 220:280-281.

Bailey, A. J., Restall, D. J., Sims, T. J. and Duance, V. C. 1979. Meat tenderness: immunofluorescent localization of the isomorphic forms of collagen in bovine muscles of varying texture. J. Sci. Food Agric. 30:203-210.

Bailey, A. J., Robins, S. P. and Balian, G. A. A. 1974. Biological significance of the intermolecular crosslinking of collagen. Nature 251:105-107.

Bailey, A.J., Knott, L., Paul, R.G. 1996. Mechanism of maturation and ageing of collagen. Mech. Ageing Dev. 106:1-56.

Bailey, A.J., Paul, R.G., Knott, L. 1998. Mechanism of maturation and ageing of collagen. Mech. Ageing Dev. 106:1-56.

Bailey, C. B., Kitts, W. D., and Wood, A. J., 1960. Changes in the gross chemical composition of the mouse during growth in relation to the assessment of physiological age. Canadian J. Anim. Sci. 40:143-155. 
Beatty, C. H., Basinger, G. M., Bocek, r. M. 1967. Differentiation of red and white fibers in muscle from fetal, neonatal and infant rhesus monkeys. J. Histochem. Cytochem. 15:93-98.

Beranal, V. M., Stanley, D. W. 1987. Stability of bovine muscle connective tissues. J. Food Sci., 52:876-881.

Bendal, J. R., Davey, C.L 1957. Ammonia liberation during rigor mortis and its relation to changes in the adenine and inosine nucleotides of rabbit muscle. Biochemica et Biophysica Acta, 26:93-103.

Berry, B. W., Smith, G. C., Carpenter, Z. L. 1974. Beef maturity indicators and palatability attributes. J. Anim. Sci. 38:507-514.

Bhattacharya, M. 1988. Effect of frozen storage conditions on yields, shear strength, and color of ground beef. J. Food Sci. 53:696-700.

Bischoff, R. 1974. Enzymatic liberation of myogenic cells from adult rat muscle. Anat. Rec. 180:645-661.

Boleman, S. J., Miller, R. K., Bnyuck, M. J., Cross, H. R., and Savell, J. W. 1996. Influence of realimentation on mature carcass on maturity, color, collagen solubility and sensory characteristics. J. Anim. Sci. 74:2187-2194.

Bosselmann, A., Moller, C., Steinhart, H., Kierchegessner, M., and Schawartz, F. J., 1995. Pyridinoline cross-links in bovine muscle collagen. J. Food Sci. 60:953958.

Brama, P. A. J., TeKoppele, J. M., Bank, R. A., Rene van Weeren, Barneveld, A. 1999. Influence of site and age on biochemical characteristics of the collagen network of equine articular catilage. A. J. V. R. 60:341-345.

Brodsky, B., Tanaka, S., Eikenberry, E. F. 1988. X-ray diffraction as a tool for studying collagen structure. In: "Collagen” Vol. 1 M. E. Nimni (ed.) CRC Press, Florida p.95-101.

Brooke, M. H., Kaiser, K. K. 1970b. Muscle fiber type: how many and what link. Arch. Neurol. 23:369-379.

Brooks, J. 1948. The oxidation of haemoglobin to met-haemoglobin by oxygen. J. Physiol. 107:332-339.

Brownlee, M. 1990. Advanced products of nonenzymatic glycosylation and the pathogenesis of diabetis complications. In Diabetes Mellitus: Theory and Practice ed. H. Rifckin, D. Porte Jr. p:279-91. New York, Elsevier. 
Brownlee, M. 1995. Advanced protein glycosylation in diabetes and aging. Annu. Rev. Med. 46:223-234.

Brownlee, M., Vlassara, H., Kooney, A., Ulrich, P., and Cerami, A. 1986. Aminoguanidine prevents diabetes-induced arterial wall protein cross-linking. Science 232:1629-1632.

Brownlee, M., Vlassare, H., Cerami, A. 1985. Non enzymatic glycosylation products on collagen covalently trap low density lipoprotein. Diabets 34:938-941.

Brownlee, M., Cerami, A.,Vlassara, H. 1988. Advanced products of nonenzymatic glycosylation and the pathogenesis of diabetic vascular disease. Diabetes Metab. Res. 4:437-451.

Bucala, R., and Cerami, A., 1992. Advanced glycosylation: Chemistry, biology, and implications for diabetes and aging. Adv. Pharmcol. 23:1-34.

Burson, D. E., Hunt, M. C. 1986. Proportion of collagen I and III in four bovine muscles differing in tenderness. J. Food Sci. 51:51-53.

Cagliero, E., Roth, T., Lorenzi, M. 1991. Characteristics and mechanisms of high glucose overexpresion of basement membrane components in cultures human endothelial cells. Diabetes 40:102-110.

Casey, J. C., Crosland, A. R., Patterson, R. L. S. 1985. Collagen content of meat carcasses of known history. Meat Sci. 12:189-203.

Cassens, , R. G. 1977. Muscle biochemistry: the importance of myofiber type. Food Technol. 31:76-81.

Cefalu, W.T., Farrow, A. D., Wang, Z. Q., Sonntag, W. E., Fu, M., Baynes, J. W., and Thorpe, S. R. 1995. Caloric restriction decreases age dependent accumulation of he glycoxidation products, $\mathrm{N}$-(Carboxymethyl) Lysine, and pentosidine, in rat skin collagen. J. Gerontol, Biol. Sci. 50A:B-337-B341.

Cefalu, W.T., Wagner, J.D., Wang, Z. Q., Bell-Farow, A. D., Collins, J., Haskell, D., Bechtold, R., Morgan, T. 1997. A study of caloric restriction and cardiovascular aging in cynomolgus monkeys (Macaca fascicularis): a potential of aging research. J. Gerontol. Series A. Biol. Sci. Med. Sci. 52:B10-B19.

Cerami, A. 1985. Hypothesis: glucose as a mediator of aging. J. Am. Geriatr. Soc. 33:626-634.

Cerami, A., Vlassara, H., Brownlee, M. 1987. Glucose and Aging. Sci. Am. 256:82-88. 
Cerami, A., Vlasara, H., and Brownlee, M. 1995. Glucose and Aging. Diabetes 90:96104.

Chace, K. V., Carubelli, R., and Nordquist, R. E. 1991. The role of nonenzymatic glycosylation, transition metals and free radicals in the formation of collagen aggregates. Arch. Biochem. Biophys. 288:473-480.

Chappey, O., Dosquet, C., Wautier, M-P., and Wautier, J-L. 1997. Advanced glycation end products, oxidant stress and vascular lesions. Eurp. J. Clinic. Invest. 27:97108.

Chen, H. J., Cerami, A.,1993. Mechanism of inhibition of advanced glycosylation by aminoguanidine in vitro. J. Carbohydr. Chem. 12:731-742.

Cockram, M. S., Corley, K. T. T. 1991. Effect of pre-slaughter handling on the behaviour and blood composition of beef cattle. British Vet. J. 147:444-454.

Coleman, S.W. 1995. Silage or limit fed grain growing diets for steers. I: Growth and carcass quality. J. Anim. Sci. 73:2609-2620.

Cover, S., Ritchey, S. J., and Hostetler, R. L. 1962. Tenderness of beef. I. The connective tissue component of tenderness. J. Food Sci. 27:469-475.

Cross, H. R., Schanbacher, B. D., and Crouse, J. D. 1984. Sex, age, and breed related changes in bovine testosterone and intramuscular collagen. Meat Sci. 10:187195.

Cross, H.R., Carpenter, Z.L. and Smith, G.C. 1973. Effects of intramuscular collagen and elastin on bovine muscle tenderness. J. Food Sci. 38:998-1003.

Cranwell, C. D., Unruh, J. A., Brethour, J. R., Simms, D. D. 1996. Influences of steroid implants and concentrate feeding on carcass and Longissimus muscle and collagen characteristic of cull beef cows. J. Anim. Sci. 74:1777-1783.

Dickerson, R. E., Gies, I. 1983. Hemoglobin: Structure, function, evolution, and pathology. The Benjamin/Cummings Publ. Co., Inc., Menlo, Pak, Calif, p:65-89.

Dikeman, M. E., Tuma, H. J., and Beecher, G. R. 1971. Bovine muscle tenderness as related to protein solubility. J. Food Sci. 36:190-193.

Dodson, M. V., McFarland, D. C., Grant, A. L., Doumit, M. E., and Velleman, S. G. 1996. Extrinsic regulation of domestic animal derived satellite cells. Endocrinology 13:109-126.

Dransfield, E. 1994. Optimization of tenderization, ageing, and tenderness. Meat Sci. 36:105-121. 
Etherington, D. J., Bailey, A. J. 1982. Metabolism of rat skin collagen : The effect of arrested development and subsequent catch-up growth in the stability of the connective tissue fibers. Collagen Rel. Res. 2:507-512.

Etherington, D. J. 1977. Stability of rat skin collagen during recovery from undernutrition. Biochem. J. 168:579-581.

Etherington, D. J.1987. Collagen and Meat Quality: Effects of conditioning and growth rate .In Advances in Meat Research", vol. 4 Pearson, A. M., Dutson, T. R., and Bailey, A J. (eds), AVI, p:351-360.

Eyre, D. R. 1981. Crosslink maturation in bone collagen. In: Veiss, A. (Ed.), The chemistry and Biology o Mineralized Connective Tissues. Elsevier North Holland, New York, p:51-55.

Eyre, D. R., Paz, M. A., Gallop, P. M. 1984. Crosslining in collagen and elastin. Ann. Rev Biochem. 53:717-748.

Fishell, V. K., Aberle, E.D., Judge. S., Perry, T. W. 1985. Palatability and muscle properties of beef as influenced by preslaughter growth rate. J. Anim. Sci. 61:151-157.

Faustman, C., and Cassens, R. G. 1991. The effect of cattle bred and muscle type discoloration and various biochemical parameters in fresh beef. J. Anim. Sci., 69:184-193.

Garrett, R. H., Grisham, C. M. 1999. Biochemistry. Sec. Ed. Saunders College Publishing, p:173-180

Giardino, I., Edelstein, D., Horiuchi, S., Araki, N., Brownlee, M. 1995. Vitamin E prevents diabetes-induced formation of arterial wall intracellular advanced glycation end products. Diabetes 44(S1):73A.

Going, S.B., Williams, D. P., Loghman, T. G., Hewitt, M. 1994. Aging, body composition, and physical activity: a review. J. Aging and Physical activity 2:3866.

Goll, D.E., Bray, R.W. and W.G. Hoekstra. 1964a. Age associated changes in bovine muscle connective tissue. III. Rate of solubilization at $100^{\circ}$ C. J. Food Sci. 29:622-628.

Goll, D.E., Hoekstra, W. G., and Bray, R.W. 1964c. Age associated changes in bovine muscle connective tissue. II. Exposure to increasing temperature. J. Food Sci. 29:615-621. 
Goll, D.E., Young, R. B., Stromer, M. H. 1974. Separation of subcellular organells by differential and density gradient centrifugation. In: 27 th Proc. Annu. Recipro. Meat Conf. Am. Meat Sci. Assoc. p:250-297.

Goll, D. E., Stomer, M. H., Robson, R. M., Temple, J., Eason, B. A., Busch, W. H. 1974. Tryptic digestion of muscle components simulates many of the changes caused by postmortem storage. J. Anim. Sci. 33:963-982.

Gramlich, H. J., Thalmann, R. R. 1930. Sex and age as factors in cattle feeding. Nebr. Agr. Exp. Sta. Bull. 252:25-28.

Hinner, R. L., and Hankins, O. G. 1950. The tenderness of beef in relation to different muscles and age in the animal. J. Anim. Sci. 9:347-353.

Harding, J. J. 1985. Non-enzymatic post-translational modifications of protein in aging. Adv. Prot. Chem. 37:247-334.

Harman, D. 1968. Free radical theory of aging: effect of free radical inhibitors on the mortality rate of male LAF1 mice. J. Gerontol. 23:476-482.

Harman, D. 1968. Free radical theory of aging: effect of free radical inhibitors on the mortality rate of male LAF1 mice. J. Gerontol. 23:476-482.

Hauschka, SD. 1994. The embryonic origin of muscle. Book: Myology p:3-96.

Hayflick, L. 1985. Theories of biological aging. Exp. Gerontol. 20:145-159.

Hedrick, W. C., and Lipsey, R. J. 1983. Carcass and palatability characteristics of beef produced on pasture, corn silage and corn grain. J. Anim. Sci. 57:791-797.

Hedrick, H. B., Bailey, M. E., Krouse, N. G., Dupey, H. P., and Legendre, M. G. 1980. relationship between volatile compound in fat from forage and grain-fed beef and sensory characteristic of steaks and raosts. Proc. $26^{\text {th }}$ European Meet. Meat Res. Workers.

Henkel, W., Glanwille, R. W., Greifendorf, D. 1987. Characterisation of a type-I collagen trimeric cross-linked peptide from calf aorta and its cross-linked structure. Detection of pyridinoline by time-of-flight secondary ion-mass spectroscopy and evidence for a new cross-links. Eur J Biochem. 1987 Jun 1;165(2):427-36.

Herring, H. K., Cassens, R. G., Briskey, E. J. 1965b. Further studies on bovine muscle tenderness as influenced by carcass position, sarcomere length and fiber diameter. J. Food Sci. 30:1049-1054. 
Hinner, R. L., and Hankins, O. G. 1950. The tenderness of beef in relation to different muscels and age in the animal. J. Anim. Sci. 9:347-353.

Hill, F. 1966. The solubility of intramuscular collagen in meat animal of various ages. J. Anim. Sci. 31:161-165.

Hood, D. E. 1980. Factors affecting the rate of metmyoglobin accumulation in prepacked beef. Meat Sci. 4:247-253.

Holliday, R. 1992. The ancient origins and causes of ageing. News Physiol. Sci. 7:3440.

Honikel, K. O. 1997. Reference methods supported by OECD and their use in Mediterranean meat products. Food chemistry, 59 (4):573-582.

Horgan, D. J., Jones, P. N., King, N. L., Kurth, L. and, Kuypers, R. 1991. The relationship between animal age and the thermal stability and cross-link content of collagen from five goat muscles. Meat Sci. 29 (3):251-262.

Huby, R., and Harding, J. J. 1988. Nonenzymatic glycosylation (glycation) of lens proteins by galactose and protection by aspirin and reduced glutathione. Exp. Eye Res. 47:53-59.

Hunt, M. C., Sorheim, O., Slinde, E. 1999. Color and heat penetration of myoglobin forms in ground beef. J. Food Sci. 64:847-851.

Iqbal, M., Kenney, P. B., Al-Humadi, N. H., and Klandorf, H., 1999b. Relationship between mechanical properties and pentosidine in tendon: effect of age, diet restriction and aminoguanidine in broiler breeder hens. Poultry Sci. 79:13381344.

Iqbal, M., Probert, L. L., and Klandorf, H. 1997. Effect of dietary aminoguanidine on tissue pentosidine and reproductive performance in broiler breeder hens. Poultry Sci. 76:1574-1579.

Iqbal, M., Probert, L. P., Alhumadi, N. H., and Klandorf, H. 1999a. Protein glycosylation and advanced glycosylated endproducts (AGEs) accumulation: an avian solution?. J. Gerontol. 54A:B171-B176.

Iqbal, M. P., Kenney, P. B., Klandorf, H. Age-related changes in meat tenderness and tissue pentosidine: effect of diet restriction and aminoguanidine in broiler breeder hens. Poultry Sci. 78:1328-1333.

Jazwinscki, S.M. 1996. Longevity, genes, aging. Science 273:54-59.

Jeremiah, L. E. 1978. A review of factors affecting meat. Tech. Bull. 1. Res. Sta. Lacombe, Alberta. 
Johnson, R. C., Chen, C. M., Muller, T. S., Costello, W. J., Romans, J. R., Jones, K. W. 1988. Characterization of the muscles within the beef forequater. J. Food Sci. 53:1247-1257.

Klandorf, H., Probert, I. L., Iqbal, M. 1999. In the defence against hyperglycemia; an avian strategy. World's Poultry Sci. J. 55:251-268.

Kopper L. C. 1984. Relationship between fertility and blood glucosse and cholesterol concentrations in Holstein cows. Am. J. Vet. Res. 45:2607-2612.

Kanungo, M. S. 1980. Book: Biochemistry of ageing. p:129-154.

Klandorf, H., Zhou, Q., and Sams, A. R., 1996. Inhibition by aminoguanidine of glucose-derived collagen crosslinking in skeletal muscle of broiler breeder hens. Poultry Sci.75:432-437.

Koohmaraie, M., Babiker, A. S., Schoeder, A. L., Merkel, R. A., and Dutson, T. R. 1988. Acceleration of postmortem tenderization in ovine carcasses through activation of $\mathrm{Ca}^{+2}$ dependent proteases. J. Food Sci. 53:1638-1641.

Larick, D. K., Hedrick, H. B., Bailey, M. E., Williams, J. E., Hancock, D. L., Garner, G. B., Morrow, R.E. 1987. Flavor constituents of beef as influenced by forage- and grain feeding. J. Food Sci. 52(2):245-251.

Laurent G. J., McAnulty, R. J., Gibson, J., 1985. Changes in collagen synthesis and degradation during skeletal muscle growth. Am. J. Physiol. 249:C352-C355.

Laurent, G. J. 1987. Dynamic state of collagen pathways of collagen degradation in vivo and their possible role in regulation of collagen mass. Review. Am. J. Physiol. 252:C1- C9.

Laurent, G. J., Sparow, M. P. Bates, P. C., Milward, D. J., 1978. Turnover of muscle protein in the fowl. Biochem. J. 176:419-423.

Last, J. A., Summers, P., Reiser, K. M. 1989. Biosynthesis of collagen crosslinks II. Invivo labeling and stability of lung collagen in rats. Biochem. Biophys. Acta 990:182-186.

Lawrie, R. A. 1985. Meat Science. $4^{\text {th }}$ ed. Pergamon Press, NY, p:23-40.

Lawrie, R. A. 1979. Meat Science. Fifth edition. Pergamon Press, Oxford p:300-310.

Lawrie, R. A. 1991. Meat Science. Fifth edition. Pergamon Press, Oxford p:48-81; 188190. 
Light, N. D., 1987. The role of collagen in determining the texture of meat. In: Advances in Meat Research, Vol. 4. A. M. Pearson, T. R. Dutson, and J. J. Bailey (eds), AVI, New York p:87-98.

Light, N. D., Bailey, A. J. 1985. Collagen crosslinking: location of pyrodinoline in type I collagen. FEBS Lett. 182:503-508.

Locker, R. H. 1960. Degree of musclular contraction as a factor in tenderness of beef.Food Res. 25:304-307.

Maekawa, T., Ratinasamy, Y. K., Atman, K. I., Forbes, W. F. 1970. Changes in collagen with age. The extraction of acid soluble collagen from skin of mice. Exp. Geront. 5:177-186.

Marsh, B. B. 1977. Symposium:The basis of quality in muscle foods. The basis of tenderness in muscle foods. J. Food Sci. 42:295-299.

Mauro, A. 1961. Satellite cell of skeletal muscle fibers. J. Biophysic. Biochem. Cytol. 9:493-502.

McAnulty, R., Laurent, G. J. 1987. Collagen synthesis and degradation in vivo. Evidence for rapid rates of collagen turnover with extensive degradation of newly synthesized sollagen in tissues of the adult rat. Collagen Rel. Res. 7:93-98.

McCormick, R. J. 1989. The influence of nutrition on collagen metabolism and stability. Reciprocal Meat Conference Proceedings, Vol. 42:137-138.

McCormick, R. J. 1999. Extracellular modifications to muscle collagen: implications for meat quality. Poultry Sci. 78:785-791.

McCormick, R., J. 1994. The flexibility of the collagen compartment of muscle. Meat Sci. 36:79-91.

McKeekan, C. P. 1940. Growth and development on the pig, with special references to carcass quality characters. III. Effect of the plane of nutrition on the form of bacon pig. J. Agr. Sci. 30:511-516.

Mc Keith, F. K., De Vol, D. L., Miles, R. S., Bechtel, P. J., and Carr, t. R. 1985. Chemical and sensory properties of thirteen major beef muscles. J. Food Sci. 50: 869-872.

Miller, J. D., Cross, H. R., Crouse, J. D., Jenkins, T. G., 1987. Effect of feed energy intake on collagen characteristics and muscle quality of mature cows. Meat. Sci. 21:287-294. 
Miller, M. F., George, S. M., Reagen, J. O. 1991. Effect of exogenous porcine somatotropin on the functional and textural characteristis of the porcine semimembranosus muscle. J. Anim. Sci. 69:1975-1982.

Mitchell, H. H., Hamilton, T. S., and Haines, W. T. 1928. Some factors affecting the connective tissue content of beef muscle. J. Nutr. 1:165-162.

Monnier, V. 1989. Toward a Maillard reaction theory of aging. Prog. Cin. Biol. Res. 304:1-22.

Monnier, V. M., Cerami, A. 1981. Non-enzymatic browning in vivo: possible process for aging of long-lived proteins. Science 211:491-493.

Morgan, J., Miller, R. K., Mendez, F. M., Hale, S., Savell, J. W., 1991. Using calcium chloride injection to improve tenderness of beef from mature cows. J. Anim. Sci. 69:4469-4476.

Morita, S., Iwamoto, H., Fukumitsu, Y., Gotoh. T., Nishimura, Ono, Y. 2000. Heterogeneous composition of histochemical fibre types in the different parts o M. longissimus thaoracis from Mishima (Japanese native) steers. Meat Sci. 54:59-63.

Moriguchi, t., Fujimoto, D. 1978. Age-realted changes in the content of the collagen crosslink, pyridinoline. J. Biochem. 72:933-935.

Nimni, M. E., snd Harkeness, R. D. 1988. Molecular structure and functions of collagen. Vol. 1 Biochemistry, M. E. Nimni eds. CRC press, Boca Raton, Florida, p:1-10.

O'Keefe, M. and Hood, E. 1982. Biochemical factors influencing metmyoglobin formation in beef from muscle differing color stability. Meat Sci., 7:209-215.

Odetti, P. R., Borgoglio, A., De Pascale A., Rolandi, A., Adezati, L. 1990. Prevention of diabetes-increased aging effect on rat collagen-like fluorecence by aminoguanidine and rutin. Diabetes 39:796-801.

Opsahl, W., Zeonian, H., Ellison, M., Lewis, D., Rucker, R. B., Riggins, R. S. 1982. Role of copper in collagen crosslinking and its influence of selected mechanical properties of chick bone and tendon. J. Nutr. 112:708-716.

Owens, F. N. and Gardner, B. A 1999. Ruminant nutrition and meat quality. Reciprocal Meat Conference Proceed. Vol. 52:25-36.

Paul, R. G. Bailey, A. J. 1999. The effect of advanced glycation end-product formation upon cell-matrix interactions. The intl. J. of biochemistry and Cell Biology, 31:653-660. 
Palson, H., and Verges J. B. 1952. Effects of the plane of nutrition on growth and the development of carcass quality in lambs. Part I. The effect of high and low planes of nutrition at different ages. J. Agr. Sci. 42:1-8.

Pearson, A. M. and Young, R. B. 1989. Muscle and meat biochemistry. Academic Press, San Diego, p:15-21.

Peter, J. B., Barnard, R. L., Edgerton, V. R., Gillespie, C.A., and Stempel, K. E. 1971. Metabolic profiles of three types of skeletal muscle in guinea pig and rabbits. Biochemistry 11:2627-2633.

Purchas, R. W. 1990. An assessment of the role of $\mathrm{pH}$ differences in determining the relative tendrness of meat from bulls and steers. Meat Sci. 27:129-140.

Purchas, R. W., Yan, X., Hartley, D. G. 1998. The influence of a period of ageing on the relationship between ultimate $\mathrm{pH}$ and shear values of beef $\mathrm{m}$. longissimus thoracis. Meat Sci. 51:135-141.

Piez, K. A. 1966. Collagen In: 'Biochemistry and Physiology of Muscle a as food.' E.J. Briskey, R. G. Cassens and J. C. Trautman, eds., University of Wisconsin Press, Madison, p:315-315.

Quaglino, D., Fornieri, C., Nanney, L. B., Davidson, J. M. 1993. Extracellular matrix modifications in rat tissues of different ages-correlations between elastin and collagen type-I messenger RNA expression and lysyl oxidase activity. Matrix 13:481-490.

Rahbar, S., Yernini, K. K., Scott, S., G, N., Lalezari, I. 1999. Novel inhibitors of advanced glycation endproducts. Biochem. Biophys. Res. Com. 262:651-656.

Rahbar, S., Nadler, J. L. 1999.A new rapid method to detect inhibition of Amadori product generated by delta-gluconolactone. Clin Chim Acta. 1999 Sep;287(12):123-30.

Reagan, J. O., Carpenter, Z. L., Smith, G. C. 1976. Age related traits affecting the tenderness of bovine longissimus muscle. J. Anim. Sci. 43:1198-1205.

Reiser, K. M., McCormick, R. J., Rucker, R. 1992. Enzymatic and nonenzymatic crosslinking of collagen and elastin. FABES. 6:2439-2449.

Reiser, K. M. 1991. Nonenzymatic glycation of collagen in aging and diabetes. Proc. Soc, Exp. Biol. Med. 196:17-29.

Reiser, K. M. 1994. Influence of age and long-term dietary restriction on enzymatically mediated crosslinks and nonenzymatic glycation of collagen in mice. J. Gerontol. 49:71-79. 
Reiser, K.,M. 1998. Nonenzymatic glycation of collagen in aging and diabetes. Soc. Exp. Biol. Med. 27:23-32.

Reiser, K. M., Hennessy, S. M., Last, J. A. 1987. Analysis of age associated changes in collagen crosslinking in the skin and lung of monkeys and rats. Biochem. Biophys. Acta 926:339-348.

Rendell, M., Nirnberg, J., Bramnan, C., Valentine, J. L., Stephen, P. M., Dodds, S., Mecer, P., Smith, P. K. Walder, J. 1986. Inhibition of glycation of albumin and hemoglobin by acetylation in vitro and in vivo. J. Lab. Clin. Med. 108:286-293.

Sajith Lal, G. B., Chithra, P. and Chandrakasan, G. 1995. The possible relevance of autoxidative glycosylation in glucose mediated alterations of proteins: An in vitro study on myofibrillar proteins. Mol. Cell Biol. 95-100.

Sanada, H., Shikata, J., Hamamoto, H., Ubeba, Y., Yamamuro, T., Takeda, T. 1978. Changes in collagen cross-linking and lysyl oxidase by oestrogen. Biochem, Biophys. Acta 541:408-413.

Schnider, S. L., and Kohn, R. R., 1981. Clini. Invest. 67:1630-1635.

Scopes, R. K. 1974. The rate and extent of glycolysis in stimulated post-mortem conditions. Biochem. J. 142:79-86.

Seideman, S.C. 1986. Methods of expressing collagen characteristics and their relationship to meat tenderness and muscle fiber types. J. Food Sci. 51:273-276.

Shackelford, S. D., Koohmaraie, M., Wheeler, T. L. 1995. Effect of slaughter age on meat tenderness and USDA carcass maturity scores of beef females. J. Anim. Sci. 73:3304-3309.

Siedeman, S. C., Cross, H. R., Smith, G. C., Durland, P. R. 1984. Factors affecting fresh meat colour: a review. J. of Food quality, 6(3):211-237.

Shimokomaki, M., Elsden, D. F., and Bailey, A. J. 1972. Meat tenderness: age related changes in bovine intramuscluar collagen. J. Food Sci. 37:892-900.

Smith, G. C., Dust, T. R., Hostetler, R. L., Carpenter Z. L. 1976. Fatness, rate of chilling and tenderness of lamb. J. Food Sci. 41:748.

Smith, G. C., Carpenter, Z. L., Cross, H. R., Murph, C. E., Abraham, H. C., Sawell, J. W., Davis, G. W., berry, B. W., and Parrish, Jr. 1984. Relationship USDA marbling and palatability of cooked beef muscle. J. Food Quality. 7:289-293. 
Smith, G. C., Cross, H. R., Carpenter, Z. L., Murphey, C.E., Savell, J.W., Abraham, H.C., 1982. Relationship of USDA maturity groups to palatability of cooked beef. J. Food Sci. 47:1100-1107.

Smith, D. M., and Doumit, M. E. 1999. Similarities and differences between avian and mammalian muscle in growth and processing. Reciprocal Meat Confrernce Procedings, 52:73-74.

Sparow, M. P.,1982. Regression of skeletal muscle of chicken wing after stretch-induced hypertrophy. Am. J. Physiol. 242:C333-C339.

Stegmann, H., Stadler, K. H. 1967. Determination of hydroxyproline. Clin. Chim. Acta 18:267-273.

Swamy, M. S., Abraham, E. C. 1989. Inhibition of lens crystalin glycation and high molecular weight aggregate formation by aspirin in vitro and in vivo. Invest. Ophtalmol. Vis. Sci. 30:1120-1126.

Syvory, L., Hodny, Z. 1993. In vitro non-enzymatic glycosylation of myofibrillar proteins. Int.J. Biochem. 25:941-946.

Tatum, J. D., Smith, G. C., Berry, B., Murphey, C. E., Wiliams, F. L., Carpenter, Z. L. 1980. Carcass characteristics time on feed and cooked beef palatability attributes. J. Anim. Sci. 50:833-840.

Torp, S., Arridge, R. S. C., Armeniades, c. D., Baer, E. 1975. Structure-property relationship in tendon as a function of age. In: Atkins, e. D. T.., Keller, A., (Eds.), Structure of fibrous biopolymers 26. Butterworth, London, p:197-221.

Thorpe, S. R., Baynes, J. 1996. Role of the Maillard reaction in diabetes mellitus and diseases of aging. Drugs and Aging 9:69-77.

Tinker, D., and Rucker, R. B. 1985. Role of nutrients in the synthesis, accumulation and chemical modification of connective tissue proteins. Physiol. Rev. 65:607-651.

Van Koevering, M. T., Gill, D. R., Owens, F. N., Dolezal, H. G., Stasia, C. A. 1995. Effect of time on feed on performance of feedlot steers, carcass characteristics and tenderness and composition of longissimus muscle. J. Anim. Sci. 73:21-28.

Vaitkevicius, P., Lane, M., Spurgeon, H., Ingram, D., Roth, G. S., Eagen, J. J., Vasan, S., Wagle, D. R., Ulrich, P., Brines, M., Wuerth, J. P., Cerami, A., \& Lakatta, E. G., 2001. A cross-llink breaker has sustained effects on arterial and ventricular properties in older rhesus monkeys. Proceedings of National Academy of Sceince, 98, 1171-1175. 
Van Laack R. L. M. 2000. Determinants of ultimate pH of meat and poultry. In $53 \mathrm{rd}$ Annual Reciprocal Meat Conference. 74-75.

Van Laack, R. L. J. M., Faustman, C., Sebranek, J. G. 1993. Pork quality and the expression of stress protein HSP 70 in swine. J. Anim. Sci. 71:2958-64.

Van Laack, R. L. J. M., Liu, C. H., Smith, M. O., and Loveday, H. D. 2000. Characterization of pale, soft, exudative broiler breasts. Poultry Sci.79:10571061

Van Laack, R. L. J. M., Smulders, F. J. M. 1989. Physical-chemical properties and cooking yiels of hamburgers prepared from accelerated processed beef. J Food Sci. 55(5):1268-1269.

Van Laack, R. L. M., Smulders, F. J. M. 1990. Color stability of bovine longissimus and psoas major muscles as affected by electrical stimulation and hot boning. Meat Sci. 28:211-221.

Vasan, S., Zhang, X., Zhang, X., Karpurniotu, A., Bernhagen, J., Teichberg, S., Basgen, J., Wagle, D., Shih, D., Terecky, I., Bucala, R., Cerami, A. Egan, J., Ulrich, P., 1996. An agent cleaving glucose-derived protein crosslinks in vitro and in vivo. Nature 382:275-278.

Voet, D. and Voet, J. G. 1995. Biochemistry. Sec. Ed. Jons Willey \& Sons, New York, 171-180.

Verzar, F. 1964. Ageing of the collagen fibre. Int. Rev. Connect. Tissue. Res. 2:244-300.

Verzijl, N., DeGroot, J., Thorpe, S. R., Bank, R. A., Shaw, J. N., Lyons, T. J., Bijlsma, J. W., Lafeber, F. P., Baynes, J. W., TeKoppele, J. M. 2000. Effect of collagen turnover on the accumulation of advanced glycation end products. J. Biol. Chem. 275:39027-39031.

Vlasara, H.R., Bucala, R. and Striker, L. 1994. Pathogenic effects of advanced glycosylation: Biochemical, biologic, and clinical implications for diabets and aging. Lab. Invest. 70:138-151.

Vlassara, H., Brownlee, M., Cerami, A., 1985. High-affinity-receptor-mediated uptake and degradation of glucose-modified proteins: a potential mechanism for the removal of senescent macromolecules. Proc. Natl. Acad. U.S.A. 82:8274-8280.

Warner, R.D. 1994. Physical properties of porcine musculature in relation to postmortem biochemical changes in muscle proteins. Ph. D. dissertation. Univ. of Wisconsin, Madison. 
Warner, R. P., Kauffman, R. G., Greaser, M. L. 1997. Muscle protein changes post mortem in relation to pork quality traits. Meat Sci. 45(3):339-352.

Warren, K. E., Hunt, M. C., and Kropf, D. H. 1996. Myoglocbin oxidative state affects internal cooked color development in ground beef patties. J. Food Sci. 61:513$515,519$.

Warner, V. V., Merkel, R. A., Smith, D. M. 1999. Composition, solubility and gel properties of salt soluble proteins from two bovine muscle types. Meat Sci., 51:197-203.

Watanabe, A., Daly, C. C., Devine, C. E. 1996. The effects of ultimate pH of meat on tenderness changes during ageing. Meat Sci. 42:670-678.

Watanabe, A., and Devine, C. 1996. Effect of meat ultimate $\mathrm{pH}$ on rate of time and nebulin degradation. Meat Sci. 42 (4):407-413.

Weiss, J. B. 1976. Enzymic degradation of collagen. Int. Rev. Connect. Tissue Res. 7:101-157.

Wheeler, T. L., Shackelford, S. D. and Kohmaraie, M. 1996. Sampling, cooking, and coring effects on Warner-Bratzler shear force values in beef. J. Anim. Sci. 74:1553-1562.

Wheeler, T. L., Shackelford, S. D. and Kohmaraie, M. 1998. Cooking and palatability traits of beef longissimus steaks cooked with a belt grill and open hearth electric broiler. J. Anim. Sci. 76:2805-2810.

Wheeler, T. L., Shackelford, S. D. Johnson, L. P., Miller, R. K., Miller, M. F., and Kohmaraie, M. 1997. A comparison of Warner-Bratzler shear force assessment within and among institutions. J. Anim. Sci. 75:2423-2432.

Wheeler, T. 1., Koohmaraie, M. 1999. The extent of proteoliysis is independent of sarcomere length in lamb longissimus and psoas major. J. Anim. Sci. 77:24442451.

Winick, M., Noble, A. 1966. Cellular response in rats during malnutrition at various ages. J. Nutr. 89(3):300-6

Winick, M., Noble, A. 1967. Cellular response with increased feeding in neonatal rats. J Nutr. 91(2):179-82.

Whiting, R. C. 1989. Contributions of collagen to the properties of comminuted and restructured meat products. Reciprocal Meat Conference Proceedings, Vol. 42:149-156. 
Wolffenbutel, B. H. R., Boulanger, C. M., Crijns, F. R. L., Huijberts, M. S. P., Poitevin, P., Swennen, G. N. M., Vasan, S., Egan, J. J., Ulrich, P., Cerami, A., Levy, B. 1998. Breakers of advanced glycation end products restore large artery properties in experimental diabetes. National Academy of Science 27:4630-4634.

Wood-Gush, D. G. M., Duncan, I. J. H., Fraser, D. 1975. In Behavior of domestic animals. Et. E. S. E. Hafez, London. Bailliere Tindall, p:182-190.

Wu, J. L., Dutson, T. R., Carpenter, Z. L. 1982. Effect of post-mortem time and temperature on bovine intramusclular collagen. Meat. Sci. 7:161-181.

Wu, J. L., Dutson, T. R., Carpenter, Z. L. 1981. Effect of postmortem time and temperature on the release of lysosomal enzymes and their possible effect on bovine connective tissue component of muscles. J. Food Sci. 46:1132-1135.

Yamauchi, M., Woodley, D. T., Mechanic, G. L. 1988. Aging and crosslinking of skin collagen. Biochem. Biophys. Res. Commun. 152:898-903.

Yamauchi, M. and Mechanic, G. L. 1988. Crosslinks of collagen. In: “Collagen” Vol: 1, N.E. Nimni (ed.) CRC Press, p:157-163.

Yamauchi, M., London, R. E., Guenat, C., Hashimoto. F., Mechanic, G. L. 1987. Structure and formation of a stable histidine-based tri-functional crosslink in skin collagen. J. Biol. Chem. 262:11428-11432.

Zepeda, . M. G., Kenney, P. B., Kastner, C. L., Schwenke, J. R. 1995. Evaluation of collagen analysis procedures in fresh and cooked beef. Procedings Vol. II, $41^{\text {st }}$ annual international congress of meat science and technology. Vol. II: E674E675.

Zinn, D. W., Gaskins, C. T., Gann, G. L., and Herick, H. B. 1970. Beef muscle tenderness as influenced by days on feed, sex, maturity and anatomical location. J. Anim. Sci. 40: 307-310.

Zimmerman, S. D., McCormick, R. J., Vadlamudi, R. K., Thomas, D. P. 1993. Age and training alter collagen characteristics in fast and slow-twitch rat limb muscle. J. Appl. Physiol. 75:1670-1674. 